UNIVERSIDADE DE SÃO PAULO

FACULDADE DE FILOSOFIA, LETRAS E CIÊNCIAS HUMANAS

DEPARTAMENTO DE LETRAS ORIENTAIS

PROGRAMA DE PÓS-GRADUAÇÃO EM ESTUDOS JUDAICOS E ÁRABES

\title{
SUSIE LEE
}

Hayyôm como uma linguagem da Aliança

que expressa "atemporalidade" em Deuteronômio

Versão corrigida

São Paulo 


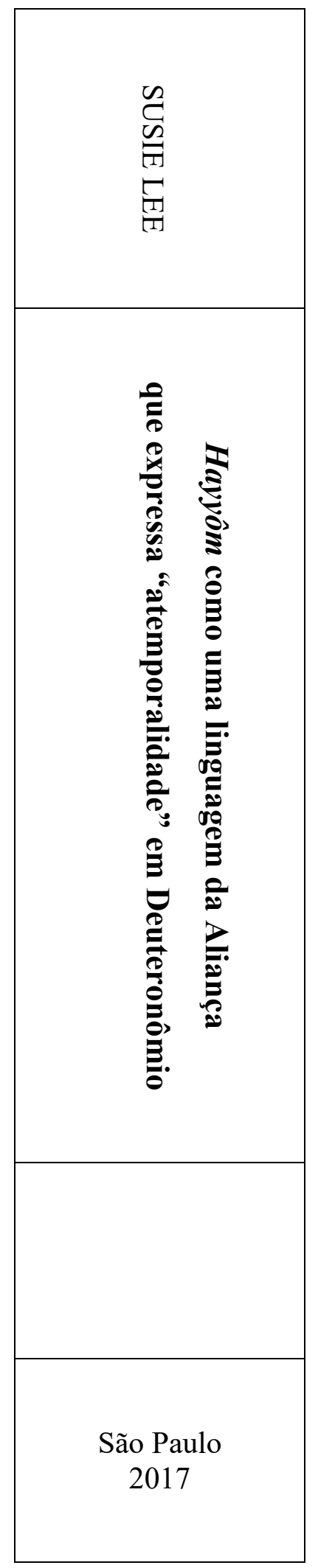




\title{
SUSIE LEE
}

\author{
Hayyôm como uma linguagem da Aliança \\ que expressa "atemporalidade" em Deuteronômio
}

\section{Versão corrigida}

Dissertação apresentada ao Programa de PósGraduação em Estudos Judaicos e Árabes, do Departamento de Letras Orientais da Faculdade de Filosofia, Letras e Ciências Humanas da Universidade de São Paulo, para obtenção do título de Mestre em Letras.

Orientador: Prof. Dr. Reginaldo Gomes de Araújo

\section{São Paulo}




\section{AGRADECIMENTOS}

Após uma jornada relativamente longa de cursos, viagens, encontros, leituras e pesquisas, é confortante demais conseguir concluir um projeto como este.

Em primeiro lugar agradeço pela paciência, orientação e apoio do meu orientador, Dr. Reginaldo Gomes de Araújo.

Agradeço também ao Dr. Walter Israel Rehfeld (in memoriam) pela obra Tempo e Religião que me instigou a me aprofundar no tema; e o apoio acadêmico particular da Dra. Suzana Chwarts que foi importante.

Agradeço de modo especial ao prof. Luiz Sayão, pelo apoio e ajuda em todos os momentos cruciais da vida; por abrir portas na busca do conhecimento e produção intelectual, além da imensa contribuição para a conclusão desta dissertação.

Agradeço igualmente a toda a minha família pela paciência e às queridas amigas, pelo apoio em oração, todo o tempo.

Agradeço ainda à IMOSP e à minha querida equipe ministerial por conceder-me a possibilidade de reservar tempo para a conclusão desta dissertação.

Finalmente, agradeço a YHWH pelo seu amor leal (hesed) imerecido que me persegue todos os dias da minha vida, conforme o Salmo 23, e hayyôm me presenteia com essa alegria especial. 
Do sagrado o homem tira o sentido da vida e, com este, força e confiança para enfrentar, vitoriosamente, os inúmeros desafios do cotidiano.

No "tempo sagrado", portanto, o caráter passageiro do tempo é superado e nele se fixam os aspectos existenciais da eternidade.

No pensamento bíblico, o tempo [momento presente] e o espaço articulam, igualmente, a identidade do que tem sido chamado "personalidade corporativa" comprometida com Deus pela Aliança, em suma a identidade de Israel. 


\section{RESUMO}

\section{LEE, Susie. Hayyôm como uma linguagem da Aliança que expressa "atemporalidade"}

em Deuteronômio. 2017. 96 f. Dissertação (Mestrado) - Faculdade de Filosofia, Letras e Ciências Humanas, Universidade de São Paulo, São Paulo, 2017.

O propósito deste trabalho é analisar a experiência temporal em Deuteronômio, que é bastante diferenciada. Por isso, analisamos o tempo na Bíblia Hebraica e, demos um destaque especial para o termo hayyôm ("hoje") deuteronômico que não se restringe a um dia em algum momento da história, mas consegue abranger todas as gerações que revivem o momento de decisão existencial no contexto da aliança entre YHWH e seu povo. Desse modo, entendemos que o passado não deixou e nunca deixará de existir, mas é sempre exigentemente um presente em que a aliança de Horebe requer que cada geração viva em obediência aos mandamentos de YHWH. Ao fazer isso, mediante uma "atualização" ou "presentificação" contínua, incute uma percepção de "atemporalidade" e uma renovação perpétua da identidade especial como povo eleito de YHWH.

Palavras-chave: Tempo. Deuteronômio. Aliança. Hayyôm. Atualização. Identidade. 


\begin{abstract}
LEE, Susie. Hayyôm as a language of the Covenant that expresses "atemporality" in Deuteronomy. 2017. 96f. Dissertação (Mestrado) - Faculdade de Filosofia, Letras e Ciências Humanas, Universidade de São Paulo, São Paulo, 2017.

The purpose of this work is to analyze the temporal experience in Deuteronomy, which is quite differentiated. Hence, we have analyzed the time in the Hebrew Bible, and we have given special emphasis to the term hayyôm, the deuteronomic "today" that is not restricted to a day at any time in history, but manages to cover all generations that relive the moment of existential decision in the context of the covenant between YHWH and His people. In this way, we understand that the past has not ceased and will never cease to exist, but is always demandingly a present in which the covenant of Horeb requires each generation to live in obedience to the commandments of YHWH. In doing so, through at a continuous "presentification", it instils a sense of "timelessness" and a perpetual renewal of the special identity as the chosen people of YHWH unfolds.
\end{abstract}

Keywords: Time. Deuteronomy. Covenant. Hayyôm. Presentification. Identity. 


\section{LISTA DE TABELAS}

Tabela 1 - Vocabulário da aliança comparativo Hebraico e Acadiano com significado --- 53

Tabela 2 - Ocorrências de Hayyôm ligado a uma incumbência especial ou experiência

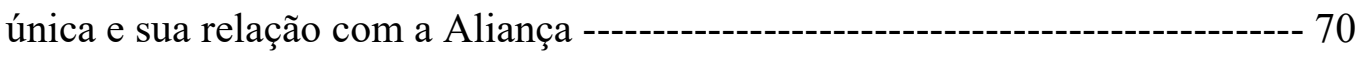

Tabela 3 - Ocorrências de Hayyôm ligado a uma lembrança da ação de YHWH (sob a fórmula: "como hoje se vê") e sua relação com a Aliança

Tabela 4 - Ocorrências de Hayyôm ligado à invocação de uma testemunha sobre um juramento ou a uma advertência e sua relação com a Aliança

Tabela 5 - Ocorrências de Hayyôm ligado a uma condição ou atividade significativa do presente e sua relação com a Aliança 72

Tabela 6 - Ocorrências de Hayyôm ligado à entrega de um decreto ou mandamento e sua relação com a Aliança 73 


\section{LISTA DE ABREVIATURAS}

\section{Abreviaturas dos Livros da Bíblia Hebraica:}

\begin{tabular}{llll} 
Gn & Gênesis & Ec & Eclesiastes \\
Ex & Exxodo & $\mathrm{Ct}$ & Cântico dos Cânticos \\
$\mathrm{Lv}$ & Levítico & $\mathrm{Is}$ & Isaías \\
$\mathrm{Nm}$ & Números & $\mathrm{Jr}$ & Jeremias \\
$\mathrm{Dt}$ & Deuteronômio & $\mathrm{Lm}$ & Lamentações de Jeremias \\
$\mathrm{Js}$ & Josué & $\mathrm{Ez}$ & Ezequiel \\
$\mathrm{Jz}$ & Juízes & $\mathrm{Dn}$ & Daniel \\
$\mathrm{Rt}$ & Rute & $\mathrm{Os}$ & Oseias \\
$1 \mathrm{Sm}$ & 1Samuel & $\mathrm{Jl}$ & Joel \\
$2 \mathrm{Sm}$ & 2 Samuel & $\mathrm{Am}$ & Amós \\
$1 \mathrm{Rs}$ & 1Reis & $\mathrm{Ob}$ & Obadias \\
$2 \mathrm{Rs}$ & 2 Reis & $\mathrm{Jn}$ & Jonas \\
$1 \mathrm{Cr}$ & 1Crônicas & $\mathrm{Mq}$ & Miqueias \\
$2 \mathrm{Cr}$ & 2Crônicas & $\mathrm{Na}$ & Naum \\
Ed & Esdras & $\mathrm{Hc}$ & Habacuque \\
$\mathrm{Ne}$ & Neemias & $\mathrm{Sf}$ & Sofonias \\
Et & Ester & $\mathrm{Ag}$ & Ageu \\
Jó & Jó & $\mathrm{Zc}$ & Zacarias \\
$\mathrm{Sl}$ & Salmos & $\mathrm{Ml}$ & Malaquias \\
$\mathrm{Pv}$ & Provérbios & & \\
\hline
\end{tabular}




\section{LISTA DE SIGLAS}

$\mathrm{ABC}$

ABD

ARA

ARC

A21

BA

BAC

BDB

$\mathrm{BH}$

BHS

BTE

CAD

DITAT

DtrH

GKC

JBL

JETS

JSOT

JSS

KBL

LXX

NET

NICOT

NDITEAT

NVI

TDOT

TDNT

TLOT

TPC

VT
Anchor Bible Commentary

Anchor Bible Dictionary

Almeida Versão Atualizada

Almeida Versão Corrigida

Almeida Versão Século 21

Biblical Archaeologist

Biblioteca de Autores Cristianos

Brown, Driver \& Briggs Hebrew Lexicon

Bíblia Hebraica

Bíblia Hebraica Stuttgartensia

Bíblia na Tradução Ecumênica

Chicago Assyrian Dictionary

Dicionário Internacional de Teologia do Antigo Testamento

Histórico-deuteronomista

Gesenius-Kautzsch Grammar

Journal of Biblical Literature

Journal of Evangelical Theological Society

Journal for the Study of the Old Testament

Journal of Semitical Studies

Koehler Baumgartner Lexicon

Septuaginta

New English Translation

The New International Commentary on the Old Testament

Novo Dicionário Internacional de Teologia e Exegese do Antigo Testamento

Nova Versão Internacional

Theological Dictionary of the Old Testament

Theological Dictionary of the New Testament

Theological Lexicon of the Old Testament

Tradução em Português Corrente

Vetus Testamentum 


\section{CONVENÇÕES E OBSERVAÇÕES TÉCNICAS}

\section{Transliteração do Hebraico:}

A transliteração do hebraico segue o padrão fonético internacional, conforme o Dicionário Hebraico-Português, de Rifka Berezin, EDUSP, 1995.

\section{Tetragrama YHWH:}

É o nome do Deus de Israel.

Foi adotada a transcrição apenas das consoantes, principalmente porque concorda com a prática hebraica tradicional, apesar de ser lido como Adonai.

Há exceções quando se refere a citações de textos bíblicos, em que aparece escrito SENHOR nas Bíblias em português, ou de outras obras, que foram mantidas conforme os textos originais.

\section{Citações de textos bíblicos:}

Todas as citações bíblicas em português deste trabalho são da Nova Versão Internacional (NVI), da Sociedade Bíblica Internacional, exceto quando sinalizada outra tradução, ou optamos pela tradução livre.

As citações bíblicas em hebraico são conforme apresentadas na Bíblia Hebraica Stuttgartensia (BHS).

\section{Citações de outros textos:}

Todas as citações de obras em línguas estrangeiras foram traduzidas por nós, exceto quando existe uma tradução em português já publicada. 


\section{SUMÁRIO}

1 INTRODUÇÃO

2 A CONCEPÇÃO DE TEMPO NA BÍBLIA HEBRAICA 14

2.1 CONSIDERAÇÕES SOBRE A CONCEPÇÃO DO TEMPO BÍBLICO 14

2.2 OS MODOS E TERMOS DE EXPRESSÃO TEMPORAL NA BÍBLIA HEBRAICA 21

2.2.1 MARCAÇÃO DO TEMPO A PARTIR DO NASCIMENTO OU MORTE DE ALGUÉM- 22

2.2.2 MARCAÇÃO DO TEMPO A PARTIR DO GOVERNO DE UM REI 23

2.2.3 MARCAÇÃO DO TEMPO A PARTIR DE ALGUM EVENTO JÁ CITADO OU DE UM ACONTECIMENTO IMPORTANTE 23

2.2.4 MARCAÇÃO DO TEMPO ATRAVÉS DAS GENEALOGIAS E GERAÇÕES 25

2.2.5 OS TERMOS UTILIZADOS PARA DENOTAÇÃO DO TEMPO E EXPRESSÕES

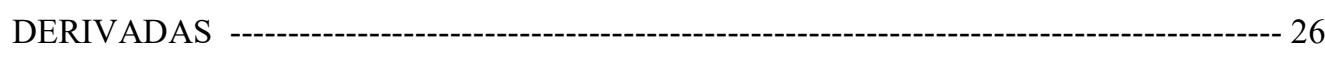

2.2.5.1 O TERMO יום 26

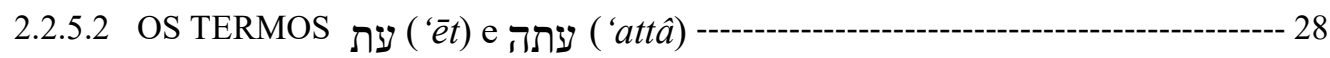

2.2.5.2.1 עת 28

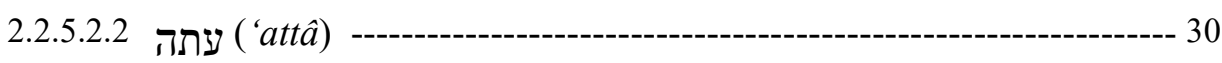

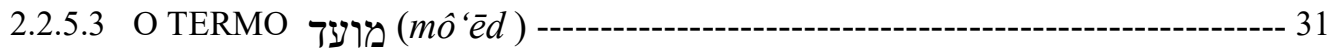

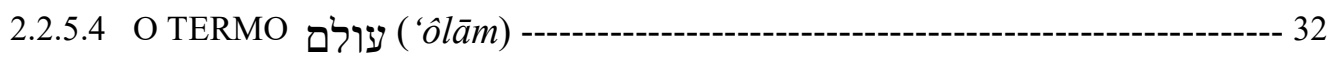

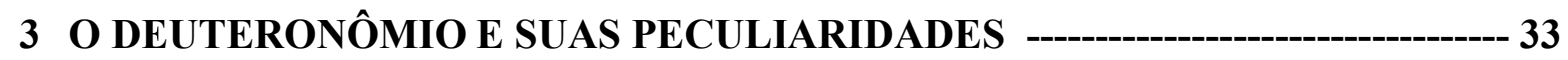

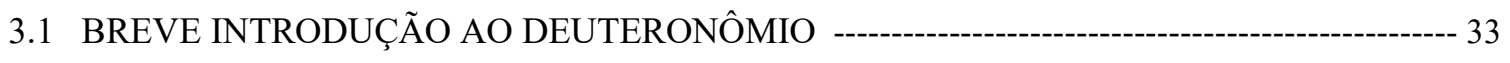

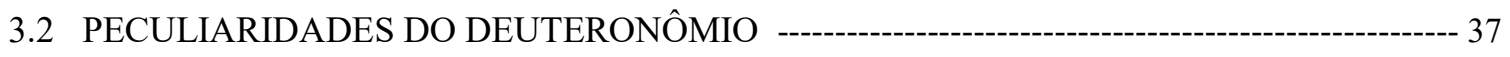

3.2.1 O ESPECTRO LITERÁRIO DO DEUTERONÔMIO -- 37

3.3 A ALIANÇA - 39

3.3.1 ETIMOLOGIA, CONCEITO E USOS DO TERMO בְּרִית (bît - ALIANÇA) NA BH --- 39 
3.3.2 A ORIGEM DA IDEIA DE ALIANÇA EM ISRAEL

3.4 DEUTERONÔMIO COMO UM TRATADO DE ALIANÇA SEGUNDO MODELO

DE TRATADO ENTRE SUSERANO E VASSALO 44

3.5 UMA COMPARAÇÃO ENTRE O DEUTERONÔMIO, O LIVRO DA ALIANÇA, COM OS TRATADOS HITITAS 49

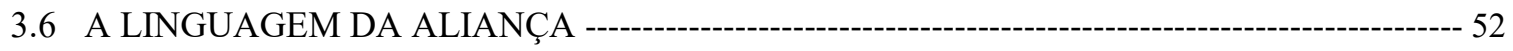

3.6.1 A LINGUAGEM ABRANGENTE DA ALIANÇA EM DEUTERONÔMIO $-54$

4 O PAPEL DO HAYYÔM 57

4.1 A CONCEPÇÃO DE "HISTÓRIA” COMO EXPERIÊNCIA TEMPORAL DIFERENCIADA DO POVO DE ISRAEL NA BH 57

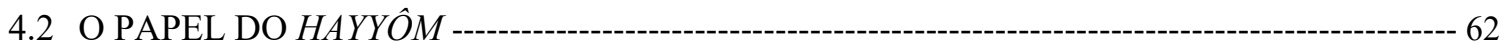

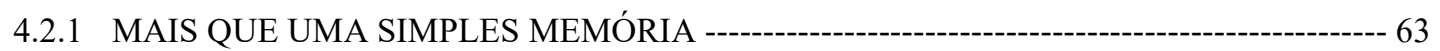

4.2.2 O HAYYÔM COMO LINGUAGEM DE “ATUALIZAÇÃO” DA ALIANÇA -------------- 66

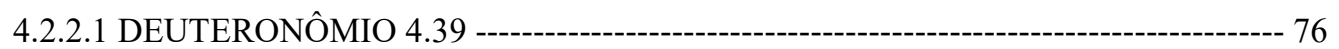

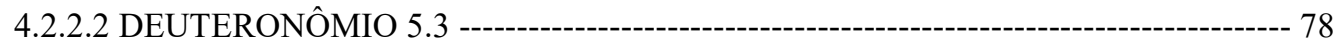

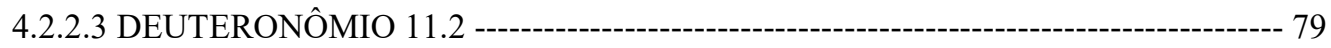




\section{INTRODUÇÃO}

"Não existe vivência humana genuína, isolada no tempo e no espaço", conforme afirmou W. Rehfeld (1988, p.38). A discussão sobre o tempo sempre foi e será relevante, justamente pelo fato de que o tempo é tão essencial à vida e à experiência humana. Levando em conta esse tema tão significativo, deve-se considerar que há grande relevância em compreender como cada cultura absorve, expressa e experiencia essa realidade.

Refletindo sobre a questão, vale ressaltar que a Bíblia Hebraica (BH) traz um espectro um tanto quanto peculiar dessa compreensão e vivência, o que o torna digno de ser abordado e estudado. No entanto, devido à complexidade e amplitude do tema, o foco do presente estudo será delimitado ao livro de Deuteronômio. Livro esse que por si só já possui suficiente riqueza em sua diversidade literária e de conteúdo. O fato é que há inúmeros escritos e discussões sobre o Deuteronômio, sua autoria e história de sua redação. Este trabalho pretende deixar de lado essa discussão infindável sobre a possível história da redação deuteronômica, e focar a atenção no Deuteronômio, isto é, no próprio texto bíblico e nas questões inerentes ao texto.

Pensando em Deuteronômio, deve-se enfatizar que um dos maiores tesouros revelados nesse "Livro da Aliança" é exatamente o pacto, a aliança de YHWH com o seu povo Israel, e como essa aliança é recapitulada e renovada a cada geração, de tal modo que a torna sempre atual à geração presente. Este trabalho mostrará como isso é possível pelo uso do recurso de “atualização", marcado nitidamente por um termo bem peculiar: o hayyôm ("hoje”) - expressão temporal que tem a força de transformar a aliança em algo sempre atual. Sobre esse assunto, W. Rehfeld sintetiza:

Israel vive num tempo todo especial, entre a eleição e a realização; um tempo de recordação da Torá, tempo de Mishné Torá, de Deuteronômio, de recapitulação do ensino divino. É o tempo em que a voz terrificante do assim chamado "Primeiro Mandamento" ressoa: "EU SOU O ETERNO, TEU DEUS, QUE TE TIREI DA TERRA DO EGITO, DA CASA DA ESCRAVIDÃO" (Ex 20.2). Esse "Mandamento" recorda um passado que não é mero passado e, sim, desafia neste mesmo momento a construir no presente um futuro melhor. [...] No Deuteronômio, este "hoje" envolve, numa única expressão, tanto o hoje de Moisés como o de qualquer outra geração posterior 
de Israel, na medida em que poderia e deveria colocar-se na posição entre a eleição e realização, permanecendo sempre a caminho (REHFELD, 1988, p. 78,79 , grifo do autor).

Considerando que a $\mathrm{BH}$ é uma das principais referências literárias da cultura e da história hebraica, a ponto de Israel ser chamado de "o povo do livro", nosso propósito é tratar do conceito de tempo na BH e do tempo como "atualização" do passado através do termo hayyôm, no contexto da aliança presente no texto deuteronômico. Esse uso peculiar nos remete ao resgate da história de Israel, além de permitir um aprofundamento de um assunto que, ao que parece, ainda é comparativamente pouco tratado.

Dessa forma, há dois grandes temas orientadores da pesquisa que necessitaram de literaturas mais específicas: o conceito de tempo na $\mathrm{BH}$ e da aliança em Deuteronômio. Por isso, num primeiro momento, será feita uma abordagem de diversas considerações sobre o tempo na $\mathrm{BH}$ e, a seguir, uma análise detalhada dos termos que denotam o conceito de tempo na $\mathrm{BH}$, entendendo o sentido e o contexto em que são utilizados, com base em autores que trabalham com uma noção de tempo diferenciada na $\mathrm{BH}$, seja sob abordagem linguística, seja de forma exegética.

No momento seguinte, trataremos de modo mais detalhado das características singulares de Deuteronômio e do conceito de aliança inerente ao livro comparado aos tratados de aliança do Antigo Oriente Próximo, pois apresentam muitas semelhanças em sua forma de apresentação e vocabulário característico. Além disso, o estudo envolve a linguagem particular utilizada em Deuteronômio, e as "fórmulas da aliança" que marcam o texto.

Para finalizar, analisaremos o uso do hayyôm como linguagem da aliança em Deuteronômio, na busca de compreensão do seu papel nessa literatura tão peculiar, tendo como conclusão a percepção da "atemporalidade" e perpetuidade causada por ele na afirmação da identidade do povo de YHWH. 


\section{A CONCEPÇÃO DE TEMPO NA BÍBLIA HEBRAICA}

\subsection{CONSIDERAÇÕES SOBRE A CONCEPÇÃO DO TEMPO BÍBLICO}

O ser vivo nasce, cresce, amadurece, envelhece e morre. Assim se resume a vida biológica de um ser, no qual todo e qualquer acontecimento discorre ao longo de uma linha imaginária chamada "tempo". Mas, o que de fato é o tempo? Muitos estudiosos e filósofos tentaram e ainda continuam tentando definir essa incômoda e profunda questão. $\mathrm{O}$ conhecido filósofo e teólogo Agostinho de Hipona (2008, XI, p. 111) refere-se a essa indefinição em Confissões: "O que é, pois, o tempo? Se ninguém mo pergunta, sei o que é; mas se quero explicá-lo a quem mo pergunta, não sei [...]”

Como pode uma experiência tão trivial e cotidiana na vida humana desafiar tanto o nosso entendimento? Talvez a falta de respostas suficientes torne ainda mais fascinante e provocadora a reflexão sobre o tema. Ainda mais quando se trata da concepção de tempo na Bíblia Hebraica, pois o tempo bíblico parece ir muito além da mera ideia de uma sucessão de acontecimentos, já que descreve experiências que apontam para uma concepção de tempo bem distinta, em intensidade e qualidade. Como, então, é possível compreender essa visão? Esse é o nosso desafio aqui.

Antes de qualquer consideração muito específica sobre o tempo, é importante ressaltar as diferenças existentes entre a visão de mundo atual predominante e a da antiguidade, bem como definir o contraste entre a visão abstrata inerente ao pensamento grego, do qual o Ocidente herda seu principal modo de enxergar o mundo, e o pensamento bíblico, hebraico e concreto. As palavras de Thorleif Boman (1970, p. 27) parecem delimitar bem essa distinção: a mentalidade hebraica é "dinâmica, vigorosa e apaixonada, e de vez em quando até explosiva; enquanto a mentalidade grega é estática [harmônica], serena, moderada [...]”.

Para Boman, aplicar ao homem bíblico os parâmetros da nossa visão de mundo ocidental e contemporânea deturparia completamente a compreensão dos textos antigos. Por isso, o estudioso norueguês propõe um contraste entre o pensamento grego e o pensamento hebraico 
bíblico, explicando que a perspectiva helênica (e ocidental em geral) trabalha com uma visão de passado, presente e futuro bem definidos, o que se verifica na própria linguagem (línguas europeias, como o grego), particularmente no uso dos verbos. Além disso, o enfoque ocidental helênico trata do passado, dizendo que esse "ficou para trás" e que o futuro está "à frente". Segundo Boman, essa visão espacial é uma herança inequívoca da mentalidade grega, uma vez que o que realmente importa não é o tempo, mas sim o espaço.

Ao contrário, a perspectiva hebraica prioriza o tempo e não o espaço, enxergando a questão do passado e do futuro de modo bem diferente: mais importante do que localizar o tempo de forma espacial é defini-lo em ações completas (acabadas) e incompletas (inacabadas). Prioriza-se o aspecto verbal (modo da ação). Isso dá nome aos próprios aspectos verbais, que denotam uma ação e não o tempo propriamente dito. Na mentalidade hebraica antiga, o passado - que, na realidade, trata-se da ação completa - está "à frente", o que pode ser atestado nas palavras que definem o tempo passado, como: 'etmôl e qedem, "ontem" ou "antigamente", que também significam "em frente"; e o futuro - ação incompleta - está "atrás", sendo que a palavra $m \bar{a} h \bar{a} r$, "amanhã" ou "no futuro", vem da raiz 'aḥar, que significa, entre outras coisas, "ficar atrás", ou "para trás"1 (BOMAN, 1970, p. 149).

A questão que devemos considerar aqui é: por que o tempo era entendido desse modo? A resposta está no fato de que a mentalidade hebraica é simples e direta. O passado está à frente, pois já foi descoberto, já é conhecido e, por isso, está “diante dos olhos” dos homens; enquanto que o futuro está "atrás", ou melhor, está "escondido", pois ainda é "desconhecido" ao ser humano. (BOMAN, 1970, p. 146)

No entanto, ao tirar suas conclusões a partir da investigação dos contrastes linguísticos, sintáticos, semânticos e estilísticos dos textos, Boman parece induzir de modo ilegítimo às distinções conceituais fundamentais das evidências linguísticas, conforme a crítica de James Barr (1961, p. 46-88). O renomado estudioso de Oxford, por sua vez, nega veementemente toda possibilidade de derivar conceitos de tempo bíblicos apenas sob uma perspectiva de análise linguística. Sua crítica abrange duas principais frentes: na primeira, ele questiona a exatidão das diferenças assumidas como verdades quanto à concepção de tempo na escolha de um léxico, apontando, por exemplo, para a presença de um tempo cíclico na concepção hebraica, assim como de traços de tempo linear em material grego (BARR, 1962, p. 141). Já em sua segunda

\footnotetext{
${ }^{1}$ Ou ainda, 'aharît, está às “costas”, cf. DITAT, p. 1318.
} 
discordância, Barr (1962, p. 25) afirma que a metodologia dessa abordagem puramente linguística não é suficiente, pois na maioria das vezes, o léxico e a estrutura da língua não correspondem à totalidade do pensamento dos falantes da língua, o que implica dizer que, ao fazer recortes apenas linguísticos, chega-se a um resultado comprometido, com grandes distorções da realidade, pois ignoram-se problemas básicos.

Barr (Ibid.), por exemplo, afirma que mesmo que haja realmente um significado diferente entre

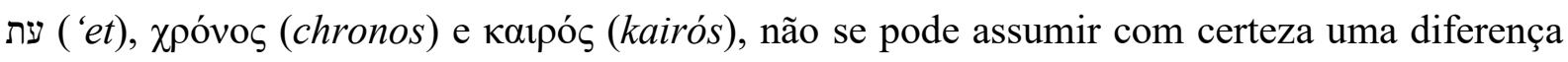
correspondente entre o modo que os falantes do hebraico e do grego pensavam sobre o tempo. Dessa forma, a escolha de um termo sob uma perspectiva puramente linguística parece ser arbitrária, a exemplo do uso de termos como 'concreto', 'abstrato', 'estático' ou 'dinâmico', que não transmite uma ideia de modo objetivo e claro, a menos que eles sejam colocados em algum tipo de escala que possa servir de parâmetro de comparação para todas as línguas, isto é, para a linguística geral, e não, apenas e especificamente, para o grego e o hebraico. Apesar disso, contrariando completamente a perspectiva de Barr (1961), John Wilch (1969) foi um dos poucos pesquisadores que tentaram elaborar uma investigação sobre a concepção bíblica de tempo baseada na análise linguística. Ele faz um estudo exegético aprofundado do termo 'et na Bíblia Hebraica, comparando-o com outras expressões temporais, na tentativa de compreender o conceito de tempo.

A despeito de toda essa discussão, através dos trabalhos de investigação linguística, é possível observar, por um lado, que há um rico vocabulário para noções temporais na língua, presente na Bíblia Hebraica, ${ }^{2}$ e uma ampla gama de temas relacionados ao tempo em boa parte do seu corpus literário. Por outro lado, não há praticamente nenhuma discussão sobre o tempo tomado como objeto de reflexão. Desse modo, além da dificuldade já citada sobre a concepção de tempo em si, encontramos questões adicionais: até que ponto o texto nos permite discutir como os autores bíblicos pensam sobre o tempo?

A pesquisa no campo da concepção de tempo bíblica tornou-se mais relevante apenas nos anos cinquenta e sessenta, e recentemente houve uma retomada do assunto pelos acadêmicos. ${ }^{3}$ Os estudiosos do século XX discutiram muito sobre a existência de diferenças ou

\footnotetext{
${ }^{2}$ Gershon Brin trata detalhadamente desse aspecto em sua obra The Concept of Time in the Bible and the Dead Sea Scrolls, 2001.

${ }^{3}$ Merecem destaque aqui algumas publicações significativas sobre o tempo na Bíblia Hebraica que foram recentemente lançadas como a de Sacha Stern: Time and Process in Ancient Judaism. Oxford: Littman Library of Jewish Civilization, 2003; e Gershon Brin: The Concept of Time in the Bible and the Dead Sea Scrolls. Leiden: Brill, 2001.
} 
limitações dos autores bíblicos em relação à concepção de tempo que nós temos hoje no mundo ocidental, como Sacha Stern (2007) que defende de modo mais radical que aqueles realmente não conheciam o conceito funcional de tempo em sua totalidade. É interessante notar que Stern não pressupõe a existência de uma compreensão hebraica específica de tempo, mas, argumenta a ausência completa de um conceito de tempo, conforme ele observa nos antigos escritos hebraicos.

Segundo Stern (2007, p. 107-112), os autores bíblicos não poderiam discutir sobre o tempo pois não tinham consciência do que é o "tempo", ao contrário, a "realidade era experimentada apenas em termos de processos", o que incluiria os processos de fenômenos observáveis e naturais, bem como os tantos processos concretos da vida cotidiana. $\mathrm{O}$ pensamento baseado em processos implica necessariamente uma interação com a realidade concreta "em termos empíricos, consistindo em um conjunto de fenômenos distintos e concretos - atividades, movimentos, mudanças, e eventos - que ocorrem simultaneamente ou em sequência" (STERN, 2007, p. 3), como por exemplo: o movimento da lua e do sol no céu no decorrer de um mês ou um dia, ou o período de gestação da mulher. Isto é, todos são processos concretos e reais, coordenados e, por isso, segundo Stern, eles não necessitam do tempo para fazê-los funcionar. E ele vai além, dizendo que o conceito de tempo é um conceito cultural e, assim, não é necessariamente compartilhado por todas as culturas da humanidade, não havendo razão para supor a existência desse conceito em toda e qualquer cultura a menos que haja evidência que o prove (STERN, 2007, p. 5), chegando assim à conclusão de que no judaísmo antigo não existe tal evidência disponível.

É possível apreender algumas lições com o trabalho de Stern: primeiro, não se pode simplesmente transportar as noções modernas de tempo para o mundo antigo, quanto mais para a Bíblia Hebraica, o que é bastante tentador por estarmos acostumados a pensar dessa forma; segundo, é preciso fazer uma análise detalhada da linguagem e das estratégias utilizadas pelos autores bíblicos para explorar a temporalidade no contexto particular do texto, como o uso de metáforas e "processos naturais" da vida cotidiana.

De maneira semelhante, pesquisadores como Marsh (1952) e Wheeler Robinson (1946) defendem que as expressões bíblicas que descrevem o tempo tendem a interligar a experiência temporal a eventos concretos, atividades e processos. John Marsh (1952) sugere que as diferenças estão diretamente relacionadas com as palavras que exprimem o tempo no hebraico antigo e no grego. 
Marsh (1952, p. 65) argumenta que o tempo bíblico é o "tempo real", distinto em seu

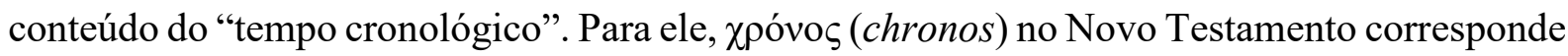
ao "tempo cronológico" e кaıpós (kairos) ao "tempo real", sendo a última a tradução mais adequada do hebraico ('et) da Bíblia Hebraica. O "tempo real” deve ser entendido em termos de oportunidade e de plenitude: "todos os eventos que ocorrem no tempo derivam de dois fatores - da oportunidade (um tempo, 'et ou kairos) que se apresenta ao homem, e da resposta do homem a essa oportunidade".

Ainda, o tempo é sempre conhecido pelo seu conteúdo. No entanto, a ação de Deus é um exemplo de tempo com "conteúdo divino" que o torna independente da sucessão cronológica, isto é, que pode ser disposto em todo e qualquer ponto da história, pois a cronologia não se aplica ao culto, em que eventos passados se tornam em presente para a congregação que celebra ao Deus que age na história. De modo semelhante, mas contrastando na sua visão de história, Robinson (1946, p. 109-111) também concorda com Marsh ao dizer que o tempo é concebido de modo concreto, em termos de conteúdo, e não como uma ideia abstrata. Para ele, o "tempo" é aquele que "encontra você na sua jornada pela vida".

No entanto, Robinson (1946, p. 53-59) observa que

a intervenção de Deus no mundo para estabelecer o seu reino não envolve a suspensão da ordem temporal; [...] o tempo [...] é sempre tempo defendendo sua visão particular de história, que se refere ao caráter definitivo do evento concreto, da atualidade e do conteúdo do tempo.

A posição do renomado antropólogo bíblico Hans Walter Wolff (2007) não se atém tanto ao aspecto linguístico, histórico ou filosófico, mas entende que há diferentes abordagens da noção de tempo dentro da Bíblia Hebraica, expressando claramente a sua visão antropológica do assunto:

As testemunhas veterotestamentárias despertam, de modo enérgico, a consciência humana para o fato de que o ser humano vive, em variadas épocas, sua vida no tempo. Em primeiro lugar, procuraremos esclarecer [...] qual a relação entre a noção de tempo e a antropologia. (WOLFF, 2007, p. 141)

Na primeira parte, ele entende o tempo como o espaço de um acontecimento de uma ação divina, sendo a história uma "sucessão de acontecimentos mutável e causadora de mudanças, orientada para uma meta" (WOLFF, 2007, p. 144). Na segunda parte, já apresenta a noção de tempo como algo refletido e diferenciado, na medida em que as datas cronológicas, além de uma estruturação do tempo no plano geral da história. No momento seguinte, ele 
argumenta que o livro de Deuteronômio lida especificamente com as questões de tempo e de história, descrevendo o passado como a dimensão do tempo para o qual o ser humano deve ser orientado, a fim de viver de acordo com a aliança. Além disso, mais adiante, ele trata do tempo determinado para cada acontecimento, do qual Deus é o senhor.

Em uma abordagem bastante semelhante, Rehfeld traz a reflexão sobre os vários contextos da experiência humana:

Não existe vivência humana genuína, isolada no tempo e no espaço; o que um
povo vivenciou foi e será vivenciado por outras nações em outras épocas e em
outras terras, apesar de múltiplas diferenças, inclusive de função e de
acentuação. Mas a vida apresenta traços significativos comuns a todos os
homens e estes traços comuns se traduzem em contextos da experiência
humana, dos quais isolaremos alguns a seguir, para neles analisar o
significado da vivência do tempo [...] as várias formas de experiência do
tempo nas diferentes culturas são comparáveis apenas no mesmo contexto
significativo, jamais de um contexto para outro (REHFELD, 1988, p. 38,
grifo do autor).

O que se pode observar é que Rehfeld adota um método fenomenológico, procurando compreender o conteúdo dos textos bíblicos como uma manifestação de um pensamento e visão de mundo coerentes com seus próprios princípios, distinta do pensamento europeu ocidental. Ele aborda diversos aspectos do tempo, dos quais faz parte o "tempo sagrado". Rehfeld argumenta que é do "sagrado" que o homem tira o sentido da vida e força para vencer os desafios do cotidiano, além de que o "sagrado" também torna o tempo duradouro, mais importante que os fatos a serem lembrados. Esse "tempo sagrado" que, segundo o autor, faz parte de toda e qualquer civilização, ainda que seja "ateísta" (REHFELD, 1988, p. 55), se manifesta no calendário de festas e celebrações, em que se recorda os momentos memoráveis da respectiva história, sendo que elas se repetem sempre, de geração a geração. Dessa forma, se essa é uma realidade em todas as culturas, é necessário buscar compreender como é o "tempo sagrado" vivido no contexto da Bíblia Hebraica, que resulta da sua cosmovisão monoteísta, em que há um único Deus criador e sustentador de todas as coisas; e também, como é o tempo que marca o encontro e a ação desse Deus na realidade e na história do povo de Israel, que revivem esses eventos através da celebração do culto.

Nessa mesma linha de pensamento, Simon De Vries (1975, p. 343-350) defende que o povo do Israel antigo tinha uma compreensão distinta de tempo, em virtude de sua visão única da história, que está relacionado com um Deus comprometido com o povo especialmente escolhido através de uma aliança, gerando uma interação contínua entre eles. E, por isso, eles 
esperavam que cada novo dia fosse qualitativamente diferente de todos os outros dias, com a expectativa de que Deus se revelasse de modo especial e decisivo. Ainda segundo De Vries, é por isso que a Bíblia desenvolveu um modo específico de se referir ao dia em termos do evento mais notável ocorrido. Em contraste com essa perspectiva, para os babilônios, os acontecimentos históricos eram fixados em uma estrutura rígida de tempo revelado pelas constelações celestes e posições dos planetas, da lua e do sol. Por isso, nada novo poderia ocorrer no tempo e na história. No entanto, o homem bíblico acreditava que o seu Deus podia encontrá-lo em qualquer lugar e momento, pois toda a história estava sob o domínio de Deus, o que dá a ele um senso de propósito e progressão.

As considerações de tantos pesquisadores sobre a concepção de tempo na Bíblia Hebraica são de grande importância para a compreensão da questão. No entanto, em diversos casos, seria importante refletir sobre quais foram as prioridades e preocupações que levaram os autores bíblicos a escolherem uma representação particular do tempo, ao invés de se ater apenas à reflexão do quão concreto ou não eles são, segundo Bundvad (2014, p. 294). Assim, ele argumenta que uma exploração das expressões temporais utilizadas com certa preferência por determinado autor, somada à análise do uso de metáforas e imagens também esclarecem muito acerca da experiência temporal humana que o autor desejava transmitir, tornando a pesquisa muito mais rica.

Após essa reflexão, devemos destacar os últimos três autores: Hans Walter Wolff, Walter Israel Rehfeld e Simon De Vries, cujos pensamentos em muito nos auxiliarão na condução da linha de raciocínio do presente trabalho, ao entender a questão do tempo específica em Deuteronômio e ligada à aliança de YHWH com seu povo; pois isso resulta na perpetuação desse tempo "experienciado" e "sagrado" de geração a geração, constituindo o que chamamos de história. Para tanto, é imprescindível entender alguns termos e modos através dos quais se marcam o tempo na $\mathrm{BH}$, como exporemos a seguir. 


\subsection{OS MODOS E TERMOS DE EXPRESSÃO TEMPORAL NA BÍBLIA HEBRAICA}

Como discutido anteriormente de modo amplo, diferentemente do que estamos acostumados na tradição do pensamento ocidental, a visão de mundo e a expressão da realidade hebraicas parecem ser mais "concretas" (talvez fosse adequado descrever essa abordagem como "fenomenológica") conforme têm concluído muitos estudiosos. Isso quer dizer que na BH quase não há espaço para conceitos e teorias abstratas, mas há expressões concretas e dinâmicas.

Não vamos encontrar definições técnicas ou conceitos abstratos sobre o tempo na Bíblia, mas sim um tempo descrito na experiência humana real, o que implica no fato de que não há medidas de tempo precisamente definidas, mas há divisões mais genéricas do tempo como manhã, tarde e noite, utilizando muitas vezes imagens e até metáforas para expressar a experiência temporal. Apesar disso, a experiência que surgiu a partir da percepção dos ritmos e da luminosidade, é expressa na língua hebraica com uma riqueza sem igual, através de uma diversidade de expressões que denotam os "momentos limítrofes entre dia e noite derivadas da observação do sol e das estrelas" (REHFELD, 1988, p. 64), assim também é expresso segundo a intensidade de luz, calor, vento, e assim por diante, conforme os exemplos:

Depois que o sol se pôs e veio a escuridão [...] (Gn 15.17)

[...] o sol quando se levanta [...] (Jz 5.31)

$[\ldots]$ até o amanhecer $[\ldots](\operatorname{Lv} 7.15)$

[...] na hora mais quente do dia [...] (Gn 18.1)

[...] desde o raiar da manhã até o meio-dia $[. .].(\mathrm{Ne} 8.3)$

[...] quando soprava a brisa do $\operatorname{dia}^{4}[\ldots](\mathrm{Gn} 3.8)$

$[\ldots]$ antes que rompa o dia e fujam as sombras $[\ldots](\mathrm{Ct} 2.17)$

O que se pode constatar é que as expressões de tempo são carregadas de significado e não de exatidão matemática e cronológica. No entanto, na ausência de um sistema universalmente aceito para a marcação do tempo, foram utilizados vários outros métodos e modos de expressão diferenciados; além disso, o povo do antigo Israel tomou emprestado de seus vizinhos alguns elementos temporais, como por exemplo, a nomenclatura dos meses, dos povos cananeus e babilônios, assim como a adição de dez ou onze dias no final do ano originário do sistema babilônico (MILLS, 1990, p. 918). A seguir, veremos algumas formas de marcação

\footnotetext{
${ }^{4}$ Em Israel, começa a soprar um ventinho fresco à tarde.
} 
do tempo utilizadas na $\mathrm{BH}$, assim como apenas alguns termos temporais mais comuns, devido à limitação do trabalho em relação ao tempo e à abrangência do tema.

\subsubsection{MARCAÇÃO DO TEMPO A PARTIR DO NASCIMENTO OU MORTE DE ALGUÉM}

Apesar das dificuldades de se delimitar a questão temporal na $\mathrm{BH}$, há muitos casos quando o texto bíblico trabalha claramente com diferentes modos de marcação de datas, que segundo Brin (2001, p. 25), geralmente são definidas com relação a algum evento ou acontecimento importante, cuja data ou período eram de conhecimento geral da época; essas datas serviam de ponto de referência no tempo. E assim, um dos métodos mais antigos era contar o tempo a partir da idade do indivíduo de quem o texto fala, isto é, o tempo era determinado pelo "tempo decorrido" a partir do nascimento do indivíduo. Por exemplo, em Gênesis 7.11, a chegada do dilúvio é descrita assim: "No dia em que Noé completou seiscentos anos, um mês e dezessete dias, nesse mesmo dia todas as fontes das grandes profundezas jorraram $[\ldots] "$.

O mesmo ocorre quando Abraão parte de sua terra, em Gênesis 12.4: “Abrão tinha setenta e cinco anos quando saiu de Harã’.

Da mesma forma, a morte também é usada como referência para se contar o tempo, mesmo que não seja expresso com exatidão. Esse tipo de marcação aparece principalmente no início dos livros, indicando a conclusão de uma era e o início de uma nova, como por exemplo, em Josué 1.1: “Depois da morte de Moisés, servo do SENHOR, disse o SENHOR a Josué, filho de Num, auxiliar de Moisés [...]”.

Essa forma aparece também marcando um evento a partir da morte de um rei importante, como em Isaías 6.1: "No ano em que o rei Uzias morreu, eu vi o Senhor assentado num trono alto..." e assim por diante. 


\subsubsection{MARCAÇÃO DO TEMPO A PARTIR DO GOVERNO DE UM REI}

De modo semelhante, a marcação do tempo pode ser feita a partir do início (coroação) ou fim (morte ou deposição) do governo de um rei, pois tornaram-se bastante importantes a partir do momento em que o regime monárquico entrou em vigor. Pode-se ver esse tipo de marcação nos exemplos de 1Reis 6.1: "[...] no quarto ano do reinado de Salomão em Israel, [...] ele começou a construir o templo do SENHOR"; e também, em Jeremias 1.2: "A palavra do SENHOR veio a ele no décimo terceiro ano do reinado de Josias, filho de Amom, rei de Judá”.

Nesse ponto, o governo dos reis são marcos tão importantes e úteis para a datação, que vale ressaltar um recurso interessante utilizado no livro de Reis: o sistema de referências cruzadas cria uma sincronia tal que consegue relacionar temporalmente os acontecimentos do reino do Norte com os do Sul. Isso pode ser observado em quase todo livro de Reis, mas seguem apenas dois exemplos: "No décimo oitavo ano do reinado de Jeroboão, filho de Nebate, Abias tornou-se rei de Judá" (1Rs 15.1); "No trigésimo primeiro ano do reinado de Asa, rei de Judá, Onri tornou-se rei de Israel" (1Rs 16.23).

\subsubsection{MARCAÇÃO DO TEMPO A PARTIR DE ALGUM EVENTO JÁ CITADO OU DE UM ACONTECIMENTO IMPORTANTE}

Outra maneira de marcar o tempo é contando-se a partir de algum evento ocorrido anteriormente, já citado, ou de um evento futuro a ocorrer, ou ainda, de um evento de conhecimento geral, como aparece em Gênesis 16.3: “[...] já fazia dez anos que Abrão, seu marido, vivia em Canaã [...]. Sarai, sua mulher, lhe entregou sua serva egípcia Hagar”.

Do mesmo modo, um evento ou acontecimento "universal" no contexto bíblico, ou que seja bastante importante e significativo, serve de referência temporal, mesmo depois de muito tempo decorrido, como é o caso do dilúvio ou do êxodo do Egito, conforme ocorre em Gênesis 
11.10: "Dois anos depois do Dilúvio, aos 100 anos de idade, Sem gerou Arfaxade".

O mesmo aparece em 1Reis 6.1: "Quatrocentos e oitenta anos depois que os israelitas saíram do Egito, [...] ele começou a construir o templo do SENHOR".

Nesses casos, geralmente os termos utilizados para fazer esse tipo de marcação são:

a) מקץ (miqēs), que descreve um momento preciso do passado, ora traduzidos como "depois de", ora como "ao fim de", ou ainda, "passado algum tempo";

b) בעוד ( $\left.b^{e} \hat{o} d\right)$ fazendo referência a um momento preciso do futuro, traduzido como "em" ou "dentro de" (x dias, meses ou anos);

c) אחר (aḩar), usado para se referir a um momento em geral, seja preciso ou não, traduzido por "depois" (BRIN, 2001, p. 30).

Esse último pode aparecer acompanhado de כז (זה (ze), como é o caso de Levítico 14.36 e em 2Crônicas 32.9, respectivamente: “Depois disso, o sacerdote irá examinar a casa”; "Mais tarde ${ }^{5}$ quando Senaqueribe, [...] e todas as suas forças estavam sitiando Láquis [...]".

Esse mesmo termo também pode ser usado na forma אחרי (aharî), seguido do evento passado ao qual se refere, como em Gênesis 13.14 ou em Gênesis 25.11, respectivamente: “[...] depois que Ló se separou dele [...]” e “depois de sepultar seu pai [...]”.

Seguindo esse mesmo raciocínio, também vale mencionar o uso dos termos לפני (lipnê), traduzido por "antes", e טרם (terem), que pode ser traduzido por "antes de" e também por "ainda não”. Exemplificando, esses termos aparecem em Números 13.22 e também em Gênesis 24.15, respectivamente: “[...] Hebrom havia sido construída sete anos antes de Zoã, no Egito”; “Antes que ele terminasse de orar, surgiu Rebeca [...]".

\footnotetext{
5 Literalmente, אחר זה “depois disso", mas, dependendo do contexto, pode ser traduzido de diversas formas.
} 


\subsubsection{MARCAÇÃO DO TEMPO ATRAVÉS DAS GENEALOGIAS E GERAÇÕES}

As genealogias na $\mathrm{BH}$ também são utilizadas para determinação do tempo e são marcadas principalmente pela palavra תולדות (tôl $\left.l^{e} d \hat{t} t\right)$, que se refere "àquilo que é produzido ou levado a existir por alguém ou por aquilo que procede de tal pessoa." (DITAT, tôlédôt, p. $621)$.

Em Gênesis, as genealogias determinam o princípio da estrutura literária geral, com dez ocorrências entre Gênesis 2.4 a 50.26, introduzidas pela expressão ēleh tôl $l^{e}$ dôt, "estas são as gerações de", ou ze sēper tôledôt, "este é o livro das gerações de": Adão (5.1), Noé (6.9), Sem, Cam e Jafé, os filhos de Noé (10.1), Sem (11.10), Terá (11.27), Ismael (25.12), Isaque (25.19), Esaú (36.1 e 9), e Jacó (37.2). No caso de Gênesis 2.4 a expressão pode causar um certo estranhamento: "Estas são as tôle dôt do céu e da terra"; no entanto, parece razoável interpretar, não como referência ao surgimento do mundo, mas aos acontecimentos que se seguiram ao estabelecimento dos céus e da terra, segundo Willeson (1958, p. 192-210), em sua obra que discute o termo Yālìd na sociedade hebraica. O uso dessa forma não se restringe a Gênesis, mas se estende aos livros de Êxodo e de Crônicas.

O mesmo ocorre com o termo דור (dôr), "geração", que é amplamente utilizado de modo direto ou indireto para determinar períodos de curta e longa duração. Esse termo se refere a um "período", isto é, "percurso em que se completa a vida humana" (REHFELD, 1988, p. 70, passim); é derivado da raiz do verbo דור (dûr) que significa "mover-se ou andar em círculos" (DITAT, p. 306), o que parece dar sentido ao se relacionar com o ciclo de vida humano, do nascimento à morte, como também quando se refere ao ciclo completo acrescido do nascimento de seus filhos, e dependendo do contexto, pode se referir a períodos mais longos e outros sentidos correlatos (DITAT, p. 306).

Por exemplo, em Gênesis 5.1ss, aparece a genealogia de Adão a Noé que totalizam dez gerações e em Gênesis 11.10-26, mais dez gerações de Noé a Abraão. É de tal magnitude a importância desse conceito que passado, presente e futuro são descritos como uma sequência de dôrot: "gerações" que sucedem uma à outra (TLOT, dôr). Desse modo, o tempo transcorrido é contado a partir dessas gerações, como se pode observar no texto de 1Reis 6.1: “Quatrocentos e oitenta anos depois que os israelitas saíram do Egito, [...] ele começou a construir o templo do SENHOR". 
É importante que fique claro aqui que os 480 anos mencionados no texto não se referem a anos exatos de 365 dias, mas seguem o princípio da contagem de doze gerações de quarenta anos cada uma, de Aarão a Zadoque, que é fundamentado na tradição judaica (TADMOR, 1962 apud REHFELD, 1988, p. 72) ${ }^{6}$. Nesse sentido, na BH, o conceito de dôrot, "gerações" exprime mais que determinação de tempo, mas também características históricas e humanas de cada época, significando a totalidade de indivíduos que vivem em determinado período, com características específicas referentes à geração contemporânea, que se diferencia de geração a geração. Num sentido mais amplo, a sequência ilimitada de gerações, expressa em ledor vadôr, “de geração a geração", pode ser usada no sentido de le'olam: "para sempre”.

\subsubsection{OS TERMOS UTILIZADOS PARA DENOTAÇÃO DO TEMPO E EXPRESSÕES DERIVADAS}

Nesta seção, nosso intuito é discutir o uso e a relevância de alguns termos relativos à marcação do tempo selecionados, mais frequentes na $\mathrm{BH}$, para compreensão do sentido e do modo como é empregado nos textos. Devido à limitação inerente a essa pesquisa, queremos deixar claro que não se trata de uma abordagem exaustiva, mas apenas o suficiente que permita a compreensão do tempo bíblico que é proposta neste trabalho.

\subsubsection{O TERMO יום (yôm)}

יום (yôm) é o mais importante conceito de tempo na BH, pelo qual é possível expressar tanto um instante quanto um período de tempo (DITAT, p. 604). A raiz semítica, cuja etimologia ainda é incerta, é muito comum: há 2.304 ocorrências em hebraico e 16 em aramaico, e está entre as cinco palavras mais frequentes da BH (TDOT, v. 6, p. 13); é comum também o termo cognato no ugarítico. A palavra não expressa uma compreensão única de tempo, podendo denotar: um período de iluminação natural (em contraste com a escuridão); um dia inteiro; uma medida do tempo cronológico; uma ideia geral e indefinida de tempo; um instante no tempo;

\footnotetext{
${ }^{6}$ TADMOR, Chayim. Cronológuia, In: Encyclopedia Mikrait. Jerusalém: Mossad Bialik, 1962.
} 
ou o período de um ano, quando aparece no plural (DITAT, p. 604).

A palavra יום (yôm) frequentemente é utilizada com preposições ou simplesmente é usada, repetindo-se a palavra, que dependendo do contexto, passa a ter um significado distinto. O uso mais comum é a preposição $b^{e}$, que corresponde a quase $70 \%$ dos casos, com 728 ocorrências; seguida pelas preposições ' $a d, k^{e}, l^{e} \mathrm{e} \min$. Por exemplo, em Gênesis 39.10, aparece yôm yôm que foi traduzido como "dia após dia" pela versão NVI; em 1Samuel 18.10 temos: $k^{e}$ yôm b yôm, traduzido por "como de dia em dia" pela versão ARC e por "como de costume" pelas versões A21 e NVI, o que denota o significado real, "como todos os dias"; mas também, quando associado com $b^{e}$, e às vezes, com 'ad e min, no qual $b^{e} y \hat{o m}$ passa a significar "quando"; como também bîmê, "no tempo de"; e $y^{e} m \hat{e}$, "enquanto".

Do mesmo modo, não é pouco frequente o uso da palavra determinada pelo artigo ה ( $h a$ ) mas ela passa a ter um sentido diferente do que seria: "o dia", ou um dia em particular, apesar de haver também ocorrências nesse sentido. Com cerca de 350 ocorrências (TDOT, v.6. p.15), היום (hayyôm) passa a significar "hoje". É muito interessante notar que apenas no livro de Deuteronômio, hayyôm ocorre 58 vezes (WOLFF, 2007, p. 146), sendo que Deus é o agente direto em sete usos e agente indireto em 49 usos da expressão, e apenas duas delas não tem ligação nenhuma com Deus (WILCH, 1969, p. 67, 68), o que demonstra uma importância considerável da expressão.

O termo יום (yôm) tem um papel fundamental na compreensão do conceito de tempo hebraico bíblico, por ser a palavra essencial para definir a noção da divisão natural do dia e da noite. Literalmente, o sentido natural de yôm é "luz", que diz respeito ao oposto de לילה (laylâ), que significa noite, ou de ערב ('ereb), que significa tarde, como também pode se referir a um dia completo, que inclui a noite, para o qual o hebraico não possui outra palavra que a denote. ${ }^{7}$ E, além das preposições, esse termo pode vir associado a diversos outros termos relacionados ao tempo, como uma espécie de complemento aos respectivos sentidos. Pode-se ver esse tipo de associação com:

1) 'ețôl, “ontem” (KBL, p. 99), como em Salmo 90.4: “[...] mil anos para ti são como o dia de ontem que passou";

\footnotetext{
${ }^{7}$ Semelhante à nossa noção de dia de 24h, no entanto, há uma grande discussão, disponível no material do TDOT, p.23, 24.
} 
2) māhạar, "amanhã" (KBL, p. 541), como em Provérbios 27.1: "Não se gabe do dia de amanhã, pois você não sabe o que este ou aquele dia poderá trazer.";

3) uma referência também a tempos remotos, distantes no passado, quando associado a qedem, "tempos antigos, passados" (DITAT, p. 1318), formando a expressão $y^{e} m e ̂$ qedem, como é o caso de Isaías 43.7: "É esta a cidade jubilosa que existe desde tempos muito antigos...?";

4) e ainda, geralmente o plural yāmîm ou a forma $y^{e} m \hat{e}$ pode vir associado a šââua, "semana"; ḥōdeš, "mês"; e šānâ, “ano".

\subsubsection{OS TERMOS עתה e ('attâ)}

\subsubsection{1 עת ('êt)}

O sentido básico e imediato desse termo na $\mathrm{BH}$ sempre se refere a tempo, podendo significar “tempo, tempo devido ou oportuno, e ocorre 296 vezes na Bíblia Hebraica." (TLOT, 'êt) Também pode denotar um tempo, ou uma ocasião, específico e determinado, como 'êt dōdîm, “idade para amar”, em Ezequiel 16.8: “[...] vi que já tinha idade suficiente para amar [...]”, ou 'êt niddâ, "época da menstruação”, em Lv 15.25: “[...] ela ficará impura enquanto durar o corrimento, como nos dias da sua menstruação."; mas essa determinação é muito discutida entre os estudiosos; o termo ainda, pode denotar um certo momento do dia (DITAT, p. 1141); no entanto, em sua essência, עת ('ēt) não é um divisor natural do tempo nem um determinante, o que implica dizer que não expressa um período de tempo, nem curto, nem longo, segundo Eronholm; em TDOT (p. 438), “'êt define a temporalidade tanto quanto māqôm delimita o espaço", contra os argumentos de Wilch (1969) e expressos no artigo do DITAT.

Já W. Rehfeld apresenta עת ( 'êt) como o “tempo identificado” (REHFELD, 1988, p. 84) de um acontecimento que é apresentado persistentemente como determinado e controlado por Deus, como demonstra o Salmo 104.27: "Todos eles dirigem seu olhar a ti, esperando que lhes dês o alimento no tempo certo". No entanto, o termo difere do tempo instituído e 
preestabelecido pela vontade divina, como é o caso do מועד (mô 'ed $)$. Inclusive, pode denotar uma ocasião habitual ou já determinada da atividade humana, de usos e costumes, um evento do curso da história, assim como um tempo determinado para a prática do culto, ou uma intervenção divina positiva ou negativa, como pode-se ver em Jeremias 8.15, ou Isaías 49.8, assim como em Jeremias 50.27, apresentados nesta ordem:

“[...] esperávamos um tempo de cura $[\ldots] "$,

"No tempo favorável (de Deus) eu lhe responderei [...]" ( 'ēt rāsôn)

“[...] Pois chegou o seu dia, a hora de serem castigados.” ( 'êt p puddâ).

Muitas vezes, 'èt também vem acompanhado pelas preposições $b^{e}, k^{e}, l^{e}$, 'ad e min, formando expressões utilizadas para fins específicos. Para definir um evento natural e regular que se repete, um tempo "devido" da natureza, ou o tempo certo para um dado acontecimento, encontramos 50 ocorrências com a expressão $b^{e} \bar{e} t+$ sufixo (p. ex. $b^{e} i t t \hat{\text { }}$ ) ou substantivo, infinitivo, ou ainda, seguido de verbo. Este é o caso:

1) da chuva, como aparece em Levítico 26.4: "eu lhes mandarei chuva na estação certa[...]";

2) da colheita, em Oseias 2.9: "[...] tornarei a tirar o meu trigo a seu tempo [...]"; 8

3) do alimento, em Salmo 145.15: "[...] e tu lhes dás o alimento no devido tempo";

4) das constelações em Jó 38.32: "Pode fazer surgir no tempo certo as constelações $[\ldots] ? "$

5) ou da intervenção de Deus em Isaías 60.22: "Eu sou o SENHOR; na hora certa farei que isso aconteça depressa."

O termo também é utilizado para o desígnio de tempo para acontecimentos que nunca podem ser repetidos, como a morte (Ec 7.17), mas aparece na forma negativa $b^{e} l \bar{o}$ ' 'ittekā: "por que morrer antes do tempo $^{9}$ ?" Ainda, é possível encontrar referências à época de migração das aves (Jr 8.7), ou de acasalamento (Gn 31.10). E quando se junta a preposição $l^{e}$ ' $\bar{t}+$ substantivo, infinitivo, ou verbo, geralmente se define um tempo ou período de alguma ação específica ou um evento, como ocorre em Isaías 17.14 ou em 2Crônicas 18.34, respectivamente: “Ao cair da

\footnotetext{
${ }^{8}$ Versão Almeida 21. Na BH refere-se ao versículo 11.

9 Literalmente, "não no seu tempo". A ARC traduz como "fora de teu tempo", mas a ideia é "antes do seu tempo", conforme a NET, ESV e NVI.
} 
tarde, pavor repentino! [...]” (le ‘êt 'ereb); “[...] e, ao pôr-do-sol, ele morreu” (le ‘èt bồ' hašemeš).

Do mesmo modo, há 22 ocorrências da forma $k^{e}$ ‘et , mas parece não existir uma diferença significativa entre $b^{e}, k^{e}$ e $l^{e}$ (TDOT, p. 441). Também há usos da expressão $k \bar{a}$ 'èt que equivale ao kāyyôm, ou kî'attâ, significando "agora”, como em Números 23.23: “[...] agora se dirá de Jacó e de Israel: "Vejam o que Deus tem feito!’”.

\subsubsection{2 עתה ('attâ)}

Esse termo é um advérbio de tempo que está relacionado ao substantivo hebraico 'êt, "tempo". Em geral, tem o sentido de "agora", mas pode significar "daqui em diante", ou "mesmo assim”, "contudo". עתה ( 'attâ) é utilizado 433 vezes na BH (TLOT, p. 957-958), com maior frequência em livros históricos ${ }^{10}$, ou caracterizados pela narrativa (TDOT, p. 437), mas também, mesmo que menos frequentes, em alguns livros poéticos e proféticos, ${ }^{11}$ geralmente em todos os tipos de discurso direto, afetando diretamente todo seu conteúdo.

Com bastante frequência 'attâ, é precedido pelo waw conjuntivo, $w^{e}$ 'attâ, "e agora", que geralmente tem a ideia da "atualização do discurso" (TDOT, p. 445) em que se requer uma ação ou reação como consequência, que ocorre em Gênesis 3.22, por exemplo: "O SENHOR Deus disse então: 'O homem tornou-se semelhante a um deus, conhecendo o bem e o mal. Agora, só falta que vá também colher do fruto da árvore da vida, para dele comer, e ter vida para sempre." "12

Além disso, também pode incluir uma conotação adversativa, "mas agora", ou "contudo", seja precedido do waw coordenativo ou não. Ainda, é relativamente comum aparecer como adjunto adverbial de tempo, em contraste com algum evento passado, ou futuro, ou ambos; e também é utilizado para marcar contextos proféticos de atuação iminente de Deus, como em Isaías 33.10: “'Agora me levantarei', diz o SENHOR. 'Agora eu me erguerei; agora serei exaltado."”

\footnotetext{
${ }^{10}$ Em ordem decrescente de número de ocorrências: 1 Samuel, Gênesis, 2 Samuel, 2 Crônicas, Juízes, 1 Reis, 2 Reis, Êxodo, Josué, Números.

${ }^{11}$ Isaías, Jó, Jeremias, Salmos, Oseias e Ezequiel.

${ }^{12}$ BÍBLIA. Tradução em Português Corrente.
} 


\subsubsection{O TERMO מועד (mô' $\bar{e} d)$}

Trata-se de um termo muito importante na Bíblia Hebraica, com 223 ocorrências (DITAT, p. 635) e se refere a um lugar ou tempo determinados e designados com um propósito; local de assembleia, estação ou festa designada. Pode se referir a um tempo combinado, em 1 Samuel 13.8: "Ele esperou sete dias, o prazo estabelecido por Samuel [...]”. Também é possível encontrar referências combinadas ao uso do 'êt, num paralelismo, por exemplo em Jeremias 8.7: "Até a cegonha no céu conhece as estações que lhe estão determinadas (mô ‘ădeyhā), e a pomba, a andorinha e o tordo observam a época ( 'êt) de sua migração".

Até os corpos celestes existem para determinar as estações, inclusive, a lua tem um papel importante no contexto das festas cúlticas, diferente do sol, por isso o Salmo 104.19 diz: "Ele fez a lua para marcar estações ( $\left.m \hat{o}^{a}{ }^{a} d \hat{\imath} m\right)$; o sol sabe quando deve se pôr". Mas esses são os casos menos frequentes (TDOT, p. 168), pois na maioria das vezes, é utilizado para designar tempo e lugar em termos cúlticos, num contexto religioso.

O uso religioso tem grande importância. Cada festa é um $m o \hat{e} ' \bar{e}$, mas do ponto de vista do coletivo, elas são $m o ̂$ ' ‘̆dê $Y H W H$, as "festas fixas, designadas pelo SENHOR", como foi proclamado em Levítico 23, numa convocação solene, instituindo as três grandes festas anuais; sem dúvida, esse é o contexto mais importante e significativo de utilização do termo: "Estas são as festas fixas do SENHOR, as reuniões sagradas que vocês proclamarão no tempo devido ..." (Lv 23.4).

Do mesmo modo, o termo se refere ao local designado, que era 'ōhel mô 'éd, a "Tenda do Encontro", onde o SENHOR encontrava-se com Moisés. Ele aparecia na nuvem junto à entrada da tenda e o "SENHOR falava com Moisés face a face, como quem fala com seu amigo" (Ex 33.11). Nesse sentido, o termo $m \hat{o}^{` a}$ dîm transmite a noção de que nesse tempo e lugar designados por YHWH, ele está mais próximo do seu povo do que em dias comuns, revelandose, falando e agindo no meio dele. 


\subsubsection{O TERMO עולם ('ôlām)}

O termo provavelmente é derivado de 'ālam, "ficar escondido", e aponta para aquilo que se encontra "escondido" no futuro ou passado distantes, pois estão num tempo em que tudo perde os contornos claros; nesse sentido, pode significar "para sempre", "sempre", "eterno", "perpétuo", "antigo" ou "mundo" (DITAT, p. 1126, 1127). Apesar de 'ôlām ser utilizado na maioria das vezes - cerca de 300 ocorrências - num sentido de progressão ou de um futuro distante, pode também se referir a um passado remoto - 20 ocorrências - ou algo antigo, como em Provérbios 22.28, por exemplo: "Não mude de lugar os antigos marcos [...] que foram colocados por seus antepassados”. Jenni (TLOT, p. 230) argumenta que possa indicar tanto um passado longínquo quanto um futuro distante, ou ainda ambos, pois o termo sempre vem acompanhado de preposições que indicam direção, como min, "desde", e 'ad, "até", le, "para", "em direção de" ou ainda, no construto, assumindo o sentido de "eternidade". No entanto, a extensão de 'ôlām depende do contexto e a que se refere: em Deuteronômio 15.17 'eved 'ôlām, "escravo para sempre", que na realidade significa "o resto da vida" (humana); já em Joel 3.20: “Judá será habitada para sempre ...", significa "por toda a sua história", (enquanto existir); também pode se referir à "desde a criação do mundo". Ao expressar a totalização do tempo, o que inclui a vida "com todos os seus conteúdos e aspectos" chega a significar "mundo".

Finalmente, quando faz referência ao El 'ôlām, "Deus eterno", o tempo infinito se aproxima da eternidade propriamente dita. Além disso, significa a "absoluta liberdade de Deus com relação a Sua criação, com relação à transformação e à decadência a ela associadas. [...] (Deus) sempre permanece no domínio de uma temporalidade concreta de um existente por Ele criado" (REHFELD, 1988, p. 99).

Após essas considerações preponderantemente linguísticas, é possível ter uma noção mais detalhada sobre diversos enfoques a respeito da compreensão, da marcação e da expressão do tempo na BH. No entanto, apesar de muitas observações significativas e valiosas, é importante destacar que não há linearidade do entendimento sobre o uso das expressões relativas ao tempo para os antigos hebreus. A tarefa é por demais difícil e complexa, devido à imensa diversidade de autores e da amplitude dos usos dos termos que abordam a temporalidade, somado ao transcurso histórico da formação da própria BH. Por isso, é fundamental definir mais especificamente um contexto menor a ser abordado. No caso do presente trabalho, o enfoque será dado ao livro de Deuteronômio. 


\section{O DEUTERONÔMIO E SUAS PECULIARIDADES}

A BH apresenta impressionante diversidade de temas e aspectos peculiares elaborados em sua rica diversidade literária. Cada livro, e até mesmo a cada capítulo ou verso que lemos, como podemos entender melhor através da exposição de Suzana Chwarts (2014a, p. 35):

A Bíblia é, antes, uma coletânea de livros de diversos gêneros, escritos,
editados e reeditados ao longo de pelo menos nove séculos, e inseridos em
molduras teológicas diversas. Os autores bíblicos empregaram meios estéticos
que nos são desconhecidos, e a escrita bíblica exibe tradições ideológicas e
artísticas de vários períodos, que desafiam sua classificação segundo os
critérios da crítica literária moderna. [...] Meu interesse, como pesquisadora é
[...] apreender dele algo da visão de mundo - modos de expressão literária,
categorias de pensamento, meio sociocultural - vigente no contexto de sua
composição.

Portanto, pretendemos explorar essa cosmovisão do mundo bíblico, ainda que de modo limitado, e o faremos, concentrando nossa atenção num contexto mais delimitado e específico do livro de Deuteronômio. Para tanto, nesta seção, vamos fazer uma breve introdução e tratar das peculiaridades do quinto livro da Torá. Destacamos que o enfoque está na aliança entre YHWH e seu povo, como condutor da História de Israel, que por sua vez, dentro de nosso objetivo aqui, trata de um modo muito peculiar como Israel vivenciava o tempo.

\subsection{BREVE INTRODUÇÃO AO DEUTERONÔMIO}

O título "Deuteronômio", historicamente usado na tradição cristã, significa "Segunda Lei" (to deuteronomion touto) e foi herdado da tradução grega Septuaginta (LXX), o que parece ter sido um entendimento equivocado do texto de Deuteronômio 17.18 que diz: "uma cópia da lei” (THOMPSON, 1982, p. 12). Esse título em nada corresponde ao título original do livro em

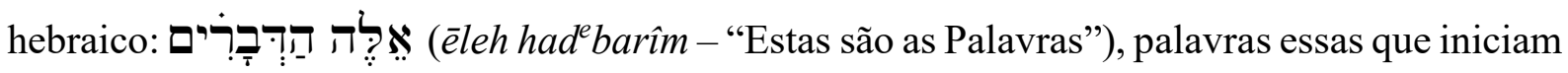
o livro. Por outro lado, esse livro é bastante conhecido na literatura rabínica como mišnêh tôrâ 
(TIGAY, 1996, p. xi) ${ }^{13}$, a "Repetição da Lei”, sendo que esse último parece fazer mais sentido quando se entende Deuteronômio como uma retomada das leis, e até mesmo uma reaplicação de algumas leis outorgadas nos livros anteriores do Pentateuco.

Essa retomada da lei é feita de modo bastante peculiar e num contexto histórico mais amplo, como veremos mais detalhadamente a seguir. Por volta do século VI a.C., definiu-se uma obra histórica de grande expressão, sem paralelos no mundo circunvizinho, composta pelos livros de Deuteronômio, Josué, Juízes, Samuel (1-2) e Reis (1-2). É possível perceber uma relação notável entre esses escritos, entre os quais Deuteronômio desempenha papel singular. O livro representa o desfecho da obra das Leis, a Torá, na qual é relatado que Deus escolheu Moisés como líder para cumprir sua promessa de redenção, tirando seu povo da escravidão do Egito e conduzindo à terra prometida. Foi com razão que a tradição vinculou o nome de Moisés à autoria da obra, já que ele é o protagonista da grande libertação do povo e seus desdobramentos culturais, religiosos e até mesmo literário.

Se, por um lado, o Deuteronômio é o desfecho da Torá, por outro lado, é o início da história do povo em sua terra (prometida). Canonicamente, o livro exerce uma função de articulação entre a promessa feita a Abraão no primeiro livro e a conquista, posse e estabelecimento na terra, no conjunto que engloba desde o livro de Josué até 2 Reis. Por isso, os rumos da pesquisa foram direcionados para a organização do conjunto de livros enquanto que definem uma certa unidade. As opções são variadas: Tetrateuco ${ }^{14}$, Pentateuco $^{15}$, Hexateuco ${ }^{16}$ e até Eneateuco ${ }^{17}$. Ao todo, são aproximadamente sete séculos da história de Israel, desde o tempo de Moisés até o exílio babilônico. Essa obra assimila tanto as tradições literárias quanto os fatos que foram diretamente vividos, com um cuidado minucioso, no qual os materiais tradicionais foram dispostos de modo sistemático e, mais tarde, foram adicionadas algumas

\footnotetext{
13 Também conforme Sipre, $\$ 160$ apud WEINFELD, 1991, p. 1.

${ }^{14}$ Inclui os quatro primeiros livros da BH: Gênesis, Êxodo, Levítico e Números, pois os Deuteronômio faria parte da obra deuteronômica (Dt - 2Rs). Os autores que defendem essa teoria são Ivan Engnell (1906-1964) e Martin Noth (1902-1968).

${ }^{15}$ A denominação é muito antiga e provém da tradução para o grego, a LXX. Entretanto, a tradição rabínica usava a terminologia Torah (Lei) para designar os cinco primeiros livros da BH, ligados à Moisés.

${ }^{16}$ Esta teoria foi propagada primeiramente por Baruch Spinoza (1632-1677). Os estudiosos modernos que deram substância a essa teoria foram August von Ewald (1803-1875), Julius Wellhausen (1844-1918) e, sobretudo, Gerhard von Rad (1901-1971). De acordo com este último autor, a principal razão para esta divisão é o conteúdo do "pequeno credo histórico" de Israel (cf. Dt 6.21-23; 26.5-9 e Js 24.2-13).

17 David Noel Freedman (1922-2008) propõe que a primeira parte da BH contenha os livros: Gênesis, Êxodo, Levítico, Números, Deuteronômio, Josué, Juízes, Samuel, Reis, formando um conjunto de nove livros sendo que o seu tema central é a "terra".
} 
novas passagens (BRUEGGEMANN; WOLFF, 1984, p. 99)

Essa obra chamada histórico-deuteronomista (DtrH) provavelmente surgiu por volta de 550 a.C. no território de Judá, conforme os estudos de Martin Noth de 1943 (apud BRUEGGEMANN; WOLFF, 1984, p. 100) ${ }^{18}$, cuja proposta foi reforçada depois por Alfred Jepsen (1953 apud Ibid.) ${ }^{19}$. E, apesar de não ser o foco específico deste trabalho, consideramos citar a DtrH com o propósito de situar toda a questão da aliança em Deuteronômio. O material de Deuteronômio 5-28 é considerado bem mais antigo no livro, e é muito provável que tenha sido encontrado em forma de rolo no templo, por volta de 621 a.C., na ocasião da reforma de Josias, conforme apresenta o relato de 2Reis 22-23. Considerando que a DtrH deriva do material do Deuteronômio, sua data deve ser posterior, ainda que a datação esteja aberta a discussões: alguns estudiosos recentemente sugeriram uma data anterior a 609, enquanto Noth (1943) e, mais tarde, Wolff (1963, p. 160-199), sugeriram que parte do material dataria de cerca do ano 561. No entanto, os detalhes sobre a datação e redação permanecem abertos à discussão.

Todavia, o que realmente importa para o presente trabalho é situar o Deuteronômio nesse contexto mais amplo, em que a história é entendida como a realização da palavra de Deus que os profetas proclamaram. E, mais especificamente, é descrita como o cumprimento das palavras de Moisés, situadas bem no início de todo o conjunto da obra do Deuteronômio. Segundo Brueggemann e Wolff (1984, p. 40), “a relação entre o deuteronômio e a DtrH é a mesma que há entre uma tradição de aliança mais antiga, usada como modelo, e uma tradição posterior, dela derivada, e que é uma renarração e redefinição mais ampla da história de Israel”.

Esse momento de retomada das leis e renarração da história de Israel remete a uma ocasião importante para o povo de YHWH. Após a libertação da escravidão do Egito e o longo período de peregrinação pelo deserto, finalmente o povo está na iminência de entrar na terra prometida, avistada do monte Nebo; essa terra, porém, é habitada por povos pagãos que adoram outros deuses. Então, antes de sua morte, o líder Moisés está diante de uma geração completamente nova que não conheceu por experiência própria YHWH nem os seus grandes feitos como os seus antepassados (Dt 11.2). Por isso, é tão crucial repetir as leis, diante das ameaças de fazer o povo perder sua identidade. Assim, os autores, ou redatores, de Deuteronômio se esforçaram para manter Israel naquilo que é essencial: um Deus, um povo,

\footnotetext{
${ }^{18}$ NOTH, Martin. Überlieferungsgeschichtliche Studien 1, Die sammelnden und bearbeitenden Geschichtswerke im Alten Testament, Tübingen, Max Niemeyer Verlag, 1943.

19 Alfred Jepsen, Die Quellen des Königsbuches, Halle, Max Niemeyer Verlag, 1953.
} 
uma lei, um templo; isso é percebido nos principais temas encontrados no livro, que segundo Tigay (1996, p. xii - xix) são:

1) Monoteísmo;

2) Lealdade a YHWH;

3) Conceito de Deus;

4) Aliança;

5) Amor;

6) Israel;

7) Israel e as nações;

8) A terra;

9) Código da Lei;

10) Centralização da adoração a YHWH e outros.

Dentre esses temas, queremos desenvolver aqui de modo resumido apenas os mais importantes que auxiliam o desenvolvimento da pesquisa proposta, que por sua vez, estão interligados.

Nesse contexto já descrito, o primeiro é um dos princípios fundamentais que delineiam o livro de Deuteronômio, isto é, a existência de um único Deus verdadeiro para Israel, YHWH. A expressão mais clara e inequívoca dessa fé israelita é o texto de Deuteronômio 6.4: "Ouça, ó Israel: O SENHOR, o nosso Deus, é o único SENHOR." (NVI). O tradicional e famoso "Shemá" nada mais é que a primeira declaração explícita a respeito do Deus único de Israel, que se tornou a confissão central da fé de Israel e a marca do monoteísmo hebraico; esse texto é tão significativo a ponto ser recitado juntamente com Deuteronômio 11.13-21, 29.4-9, e Números 15.37-41 nas orações diárias desse povo (THOMPSON, 1982, p. 117). O "Shemá" consiste em apenas quatro palavras, mas tem um significado de grande impacto:

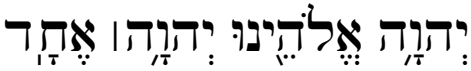

(YHWH 'ělōhênû YHWH 'ehād - YHWH, nosso Deus, YHWH, Um)

Especialmente na tentativa de traduzir a palavra 'eḥ̂ad, a expressão tem diversas outras traduções possíveis:

“[...] Nosso Deus é Javé, é só Javé” (Tradução norte-coreana, tradução e grifo nosso);

“[...] o SENHOR é nosso Deus, o SENHOR somente" (Tradução alternativa da NVI) ${ }^{20}$;

“[...] o SENHOR nosso Deus é o único SENHOR” (ARC);

20 Tradução alternativa que aparece na nota de rodapé da NVI. 
Embora existam várias traduções, o significado essencial é que YHWH deve ser o único alvo da adoração, lealdade e amor do seu povo, "pois o SENHOR, o seu Deus, é o Deus dos deuses e o Soberano dos soberanos, o grande Deus, poderoso e temível [...]” (Dt 10.17). E, em contraste com o politeísmo canaanita, Deus é um. Esse Deus único é quem age na história humana, guiando, salvando e protegendo contra os inimigos e contra os males. Israel, por sua vez, é o povo escolhido por YHWH entre as nações, conforme diz Deuteronômio 7.6: "Pois vocês são um povo santo para o SENHOR, o seu Deus. O SENHOR, o seu Deus, os escolheu dentre todos os povos da face da terra para ser o seu povo, o seu tesouro pessoal".

Essa escolha implica um convite a responder com amor e obediência ao “amor leal”, DITAT, p. 500) $)^{21}$ demonstrado por Deus em favor do seu povo, mas também, implica uma missão, pois Israel passa a ser responsável pela figura de Deus neste mundo.

\subsection{PECULIARIDADES DO DEUTERONÔMIO}

\subsubsection{O ESPECTRO LITERÁRIO DO DEUTERONÔMIO}

O livro de Deuteronômio traz consigo uma ampla variedade de gêneros literários: histórias, poemas e canções, diálogos, leis, instruções e ensino. Por essa complexidade que apresenta, é quase impossível conseguir cercar a obra sob uma perspectiva única, mas é importante compreender o contexto literário como um todo (SÁNCHEZ, 2002, p. 32). Nesse sentido, é possível fazer uma leitura de diversos pontos de vista, sem incorrer necessariamente em "erro", pois é possível ler a obra e obter um "olhar" diferenciado. Independentemente do ponto de vista particular, o próprio nome do livro sugere que "essas palavras" devem ser inculcadas no coração do povo de Israel para serem proclamadas de geração à geração, obedecidas em resposta ao amor de YHWH já demonstrado e vividas na prática no seu dia a dia.

\footnotetext{
21 Amor que envolve lealdade no cumprimento da aliança.
} 
Quando se lê o livro de Deuteronômio, é possível notar uma grande variedade de unidades literárias, o que dá a impressão de certa descontinuidade; diversas vezes, há uma mudança de um tema para outro, apresentando interrupções do fluxo de pensamento; percebese também uma grande repetição de vocabulário e mudanças de estilo. Entretanto, é notável que, apesar de tudo, formam uma unidade, sobre a qual Thompson (1982, p. 21) sintetiza: "o livro como um todo sugere a impressão de um mosaico notavelmente complexo de muitas peças de material tradicional, de grande variedade, que tenham sido fundidas de modo a formar uma unidade.” E nessa mesma linha de raciocínio, é interessante como Von Rad explica a questão:

O Dt nada mais é do que um artístico mosaico de muitos sermões sobre os mais variados assuntos; nele temos, portanto, a síntese de uma atividade de pregação que evidentemente era muito vasta. As mais diversas tradições históricas, cúlticas, jurídicas - convergiram para esses pregadores. Eles, por sua vez, incorporaram todo esse material, constituído de várias camadas literárias, naquele imenso quadro geral que foi esquematizado para representar o povo de Israel e de que também nós costumamos inicialmente nos lembrar ao imaginar Israel no deserto. Entretanto, esse quadro geral, no qual agora tudo parece constituir uma unidade orgânica, é, por sua vez, o resultado de uma intensa harmonização de muitas tradições originariamente independentes. Apesar disso, agora a unidade é tão coesa que qualquer leitor que não for previamente alertado não imaginará que a tradição dos patriarcas, dos mandamentos do Sinai e da caminhada no deserto e, sobretudo, que as numerosas ordens jurídicas e cúlticas tivessem, na sua maioria, existido originariamente independentes entre si e constituído uma confluência proveniente de múltiplos ambientes (VON RAD, 2006, p. 217).

Também é possível verificar a presença de um vocabulário e estilo bem característicos e peculiares, conferindo certa uniformidade ao livro, mas não significa que sejam exclusivos do Deuteronômio: “Assim, não há apenas unidade estrutural em Deuteronômio, mas também uma forte unidade estilística, destacada por sua simplicidade, sua lucidez, sua fraseologia e seu caráter retórico" (THOMPSON, 1982, p. 21). Alguns estudiosos tentaram explorar essa questão, fazendo uma descrição de tal vocabulário e estilo deuteronômico, como S. R. Driver (1902, p. lxxvii-lxxxiv), no início do século XX, trabalho que resultou num padrão que permaneceu por quase um século, e ainda parece ser a melhor e mais completa lista disponível. Mais recentemente, M. Weinfeld (1992, p. 320-365) incluiu referências a essa lista de vocabulário, inclusive em outras áreas da $\mathrm{BH}$ em que há ocorrências de vocabulário característico, organizando-a em torno de temas teológicos, como a luta contra a idolatria, a centralização do culto, a aliança e a eleição, a observância da lei e a lealdade à aliança, o êxodo, o credo monoteísta e outros (THOMPSON, 1982, p. 31). 


\subsection{A ALIANÇA - תִִּּרִ $\left(b^{e} r i ̂ t\right)$}

Nesta seção, discorreremos sobre a questão da aliança, que é uma coluna vertebral em Deuteronômio e um dos objetos de estudo da presente pesquisa. Primeiramente, a abordagem será feita no contexto da $\mathrm{BH}$ e, a seguir, estreitaremos seu significado no contexto deuteronômico.

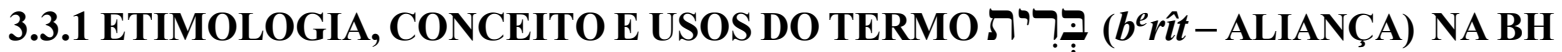

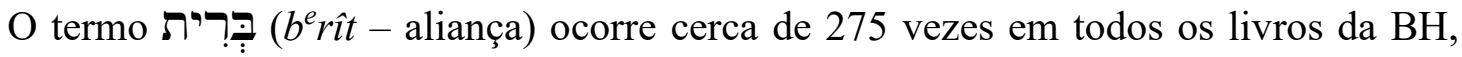
“exceto em Rute, Ester, Eclesiastes, Cântico dos Cânticos, Lamentações, Joel, Obadias, Jonas, Miqueias, Naum, Habacuque e Ageu. Aparece cerca de 80 vezes no Pentateuco, 70 vezes no Profetas Anteriores, 75 vezes nos Profetas Posteriores e 60 vezes nos Escritos." (SMITH, 2001, p. 140)

O termo pode significar tratado entre nações; aliança de amizade; acordo ou trato entre indivíduos, como em Gênesis 21.22-24; 26.23-33 e 1Samuel 18.3; 23.18; ou uma obrigação entre um monarca e seus subordinados como é usado em 2Samuel 5.3 e 2Reis 11.17; entre estados e seus representantes, conforme em 1 Reis 5.1-12; 15.19 e 20.34; uma constituição; e entre marido e esposa, como aparece em Ezequiel 16.8; Malaquias 2.14 e Provérbios 2.17; ou ainda, uma aliança acompanhada de sinais, sacrifícios e um juramento solene que selava a aliança com promessas de bênção para quem a guardasse e de maldição para quem a quebrasse, entre Deus e o homem (DITAT, p. 214-217). É também empregada num sentido figurado e incomum de aliança entre pessoas e animais, em Jó 5.23; 41.1-4; pessoas e pedras, em Jó 5.23; uma pessoa e seus olhos, em Jó 31.1; e entre uma pessoa e a morte, em Isaías 28.15-18 (SMITH, 2001, p. 140).

Já os profetas do século VIII a.C. utilizaram pouco o termo $b^{e}$ rît, sendo que Amós nunca usou o termo para se referir ao relacionamento de Deus com Israel; no entanto, é bastante claro 
que as denúncias que fez, eram infrações da lei da aliança. No caso de Oseias, talvez o único profeta literário do século VIII a.C. a usar o termo, ainda que raramente, fundamenta-se no êxodo, nas peregrinações pelo deserto, na conquista e nas estipulações da aliança de YHWH do Sinai. Jeremias também permaneceu nas tradições do reino do Norte, baseado na aliança do Sinai, insistindo que Israel havia quebrado sua aliança com Deus, conforme está registrado em Isaías $11.3-10 ; 22.9 ; 31.32$ e 34.18.

Desde meados do século XX, estudiosos da BH têm desenvolvido uma intensa discussão sobre o significado desse termo; Begrich $(1944)^{22}$ publicou um artigo em que afirmava que $b^{e} r i \hat{t}$ se referia a um relacionamento entre duas partes desiguais, no qual o suserano deveria dar ao servo ou vassalo a garantia de proteção e cuidado. Nessa relação, somente o suserano tinha obrigação enquanto o vassalo era completamente passivo. Ele acreditava que a aliança de YHWH com Israel originalmente era uma aliança de promessa e garantia. "Foi só depois que Israel estabeleceu-se em Canaã e adotou concepções cananeias de lei, que a $b^{e}$ rît de doação passou para uma $b^{e}$ rît contratual, com obrigações de ambas as partes" (1944 apud SMITH, op. cit., p. 139) ${ }^{23}$. Já Ernst Kutsch (1973 apud Ibid., p. 140) ${ }^{24}$ fez um estudo mais completo abordando contextos dos diversos usos da palavra $b^{e}$ rît na $\mathrm{BH}$, concluindo que o significado básico do termo seria "obrigação".

No entanto, a etimologia do termo é incerta. E muitos estudiosos ainda debatem sobre esse assunto. ${ }^{25}$ Alguns relacionam o termo hebraico à palavra acadiana burru, que significa "estabelecer uma situação legal por meio de um testemunho acompanhado de juramento" (CAD 2, p. 125). Todavia, através de uma lista das alternativas da origem do termo hebraico didaticamente organizada ficará mais fácil visualizar que o termo hebraico pode estar relacionado a:

a) A raiz brh (“comer"), e assim como "comer juntos" como forma de simbolizar o relacionamento e ligada à porção envolvida na refeição da aliança p. ex: Gênesis 31.54; Êxodo 24.11 (KÖHLER, JSS, 1:4-7);

b) O homônimo brh "ver", "buscar", “determinar”, “decidir”, resultando no significado

\footnotetext{
22 BEGRICH, Joachim. Berit, Ein Beitrage zur Erfassung einer alttestamentlichen Denkform, 1944.

${ }^{23}$ Ibid., p.1-11.

${ }^{24}$ KUTSCH, Ernst. Verheißung und Gesetz. Beihefte zur Zeitschrift fur Alttestamentliche Wissenschaft 131, 1973.

${ }^{25}$ Ver discussão completa da etimologia de $b^{e} r i \hat{t}$ em BARR, Some Semantic Notes on the Covenant, p. 23-38; NICHOLSON, God and His People, p. 94-109; TDOT, v.2, p. 253-255; e ZIMMERLI, Old Testament Theology in Outline, p. 49.
} 
"o que foi decidido";

c) Uma raiz biconsonantal original $b r$, separar, significando "algo especial”, privilégio ou vantagem especial;

d) O substantivo acádico birtu, significando "gancho" ou "cadeia"; ou ainda, "apertar", “atar" ou "aguilhoar" (LORETZ, VT, 16:239-41);

e) Uma preposição baseada na analogia da preposição acádica birit, "entre".

Como podemos observar, a etimologia não nos fornece uma resposta definitiva sobre o significado de $b^{e}$ rît, além de apresentarem falhas, e assim, não dá conta satisfatória das peculiaridades linguísticas de $b^{e}$ rît nem do amplo leque de uso da palavra na $\mathrm{BH}$, segundo Barr (1977 apud SMITH, 2001, p. 141) ${ }^{26}$. Por isso, o foco do seu estudo concentrou-se nos usos peculiares do termo e não na etimologia, descobrindo quatro aspectos do comportamento gramatical incomum de $b^{e}$ rît que classificou em: (1) obscuridade, (2) "idiomaticidade", (3) nãopluralização e (4) a forma peculiar de seu campo semântico. Em suma, o significado do termo deve ser buscado por meio de um estudo de seu uso.

Entendidos os aspectos gerais da etimologia, é interessante perceber como a aliança e as celebrações de aliança faziam parte do dia a dia no Israel antigo. Com isso, os relacionamentos eram estabelecidos, confirmados e renomeados, além dos laços naturais de parentesco. E esses "contratos" eram selados de diversas maneiras, por exemplo, através de palavra de compromisso ou de juramento, ou após oferecer um sacrifício, as partes compartilhavam juntas uma refeição, como é o caso de Jacó e Labão em Gênesis 31.54, 55. Também era uma prática comum levantar uma coluna de pedra para estabelecer um tratado entre duas famílias ou nações, conforme registrado em Gênesis 31.44-47. Um casamento entre duas famílias reais também podia selar um acordo, segundo pode ser lido em 1Reis 9.16. E, geralmente, fazia-se um apelo à divindade como testemunha, e isso significava a demonstração da inalterabilidade da aliança. Porém, conforme o verbete do DITAT, "a melhor maneira de se estabelecer uma aliança veio a ser o documento escrito, que existe em grande quantidade, em que as palavras da aliança, seus termos na forma de promessas e condições, eram lidas, testemunhadas, assinadas e seladas" (HILLERS, 1969 apud DITAT, p. 125) ${ }^{27}$, e como Behm conclui: "Não há garantia mais firme de segurança legal, paz ou lealdade pessoal do que a

\footnotetext{
${ }^{26}$ BARR, J. Some Semantic Notes on the Covenant. In: Beiträge zur alttestamentlichen Theologie; Festschrift für Walther Zimmerli zum 70. Geburtstag, ed. H. Donner, R. Hanhart, and R. Smend, 1977, p.23-38.

${ }^{27}$ HILLERS, D. R., Covenant: the History of a Biblical Idea, 1969.
} 
aliança" (TDNT, v. 2, p. 115).

Quanto ao conceito de aliança na $\mathrm{BH}$, é imperativo lembrar o inegável caráter morallegal da aliança do Sinai, mas como já foi exposto, as tribos israelitas absorveram e emergiram de culturas que possuíam noções altamente desenvolvidas de lei e moralidade, como exemplo, o Código de Hamurabi. E a própria Bíblia reconhece a existência de uma lei moral universal à qual todos os homens estão sujeitos desde os tempos primevos. A pergunta que se levanta então é: havia alguma novidade na aliança entre YHWH e Israel? Segundo Y. Kaufmann (1989, p. 222), definitivamente sim:

O elemento distintivamente novo nas leis da aliança do Sinai não foi o seu conteúdo. A novidade estava na própria doação. Pela primeira vez, a moralidade foi representada como revelação profética, expressão do supremo arbítrio moral de Deus. Não era a doutrina dos sábios, ou a ordem dos governantes, tampouco a sabedoria de um deus que revelava leis juntamente com outras questões de arte e ciência (como as leis de Tot, Oanes etc.). Esta lei era o mandamento de um Deus, o seu arbítrio absoluto. A ideia foi expressa numa lenda sem paralelo: Deus revelou-se a um povo inteiro e não a um visionário, a um sacerdote ou a um sábio. Os homens ouviram o mandamento da boca de Deus.

Além disso, YHWH elegeu Israel não com o intuito de fundar um "novo culto mágico em benefício dele", nas palavras de Y. Kaufmann, mas Deus o elegeu para ser o seu povo e para realizar nele e através dele, a sua vontade. Então, a natureza da aliança é tanto religiosa quanto moral-legal, o que envolve o culto, mas também a estrutura e as leis éticas e morais da sociedade, na qual ambas são expressões da vontade divina. Já D. J. McCarthy discorda em parte de Y. Kaufmann, afirmando que "[...] apresenta uma tradição complexa e muito rica e que a aliança não é em primeiro plano legalista ou moralista, mas sim cultural, isto é, vinculada à prática religiosa." (apud DITAT, p. 216)

Vale ressaltar que estudiosos como W. Eichrodt (2005) entendem o conceito de aliança como tema central e unificador da BH. Ele defende que é o conceito de aliança que, de certa forma, comprova que a religião de Israel era histórica; e consegue colocar em evidência o elemento fundamental de toda a experiência do povo de YHWH: o caráter "efetivo" da revelação divina. "Pois YHWH dá a conhecer seu próprio ser atuando na vida de seu povo e modelando-o conforme a sua vontade" (EICHRODT, 2005, p. 34). Para ele, a aliança não é apenas um conjunto de exigências, mas principalmente uma promessa, como diz em Êxodo 6.7: "Eu os farei meu povo e serei o Deus de vocês. Então vocês saberão que eu sou o SENHOR, o 
seu Deus, que os livra do trabalho imposto pelos egípcios". Desse modo, a própria aliança é que dá finalidade à vida, e sentido à história, além de servir como fio condutor para a formação da mesma.

\subsubsection{A ORIGEM DA IDEIA DE ALIANÇA EM ISRAEL}

No fim do século XIX, houve estudiosos que defenderam um surgimento tardio da ideia de aliança no desenvolvimento da religião de Israel. A sugestão é que a ideia teria ocorrido sob a influência dos profetas do século VIII a.C., mas isso agora deve ser questionado, segundo Thompson (1964, p. 26). Desde os tempos mais remotos, os antepassados de Israel tinham plena consciência da existência de uma relação pessoal profunda entre eles e o seu Deus, YHWH. Na BH é possível verificar que era comum vincular o nome do chefe de um clã com a divindade de um modo especialmente íntimo e pessoal, como aparece nas expressões: "Deus de Abraão", “o Temor de Isaque”, “o Poderoso de Jacó”. Já os povos do Antigo Oriente Próximo passaram a ter na divindade, a garantia de "terra" para habitar e "descendência" para herdar as terras da promessa; e isso também pode ser percebido no povo hebreu através das promessas feitas por YHWH a Abrão, no livro de Gênesis 12.1-2: "Saia da sua terra, do meio dos seus parentes e da casa de seu pai, e vá para a terra que eu lhe mostrarei. Farei de você um grande povo, e o abençoarei”.

A partir desses pressupostos, passou a ser necessário ter um documento que listasse tanto as condições do tratado quanto as "bênçãos" e "maldições" que também continham referências à família e terras (PRITCHARD, 1958, p. 205). Então, ao examinar a BH e a história, parece que as tribos de Israel já tinham uma certa predisposição a aceitar o conceito de aliança pelo contexto em que viviam e estavam inseridos; mas, foi a partir da experiência da milagrosa libertação do Egito, após centenas de anos de escravidão, que esse povo passou a declarar o Deus de seus antepassados seu poderoso libertador. Agora, ele passava a ser conhecido pelo nome YHWH, deixando de ser apenas uma divindade íntima e pessoal para também ser seu Rei, que deseja conceder-lhes "terra" e "descendência" por sua vontade 
soberana. Como seu Rei soberano, ele os convida a entrar numa relação de aliança com Ele, assumindo obrigações mais definidas.

É daí que surge o "contexto vital" 28 de uma ideia que não era completamente estranha aos antepassados de Israel, especialmente aos do norte da Mesopotâmia, que talvez teriam sido forçados a realizar tratados locais com os poderosos da cidade de Mari. Após a chegada em Canaã, onde já existia um sistema feudal egípcio, esse contato deve ter aumentado. Por essas razões, na realidade, quando Israel finalmente surgiu como nação, os israelitas já tinham uma vasta experiência com diversos tipos de relação de aliança que serviriam também para fundamentar a sua fé. E, de fato, parece ter sido Moisés o primeiro a fazer uso da metáfora do suserano e vassalo para expressar a ideia de soberania de YHWH sobre Israel, quando definiu o prólogo histórico, mostrando como YHWH demonstrara hesed pelo seu povo, e como o próprio YHWH convida Israel a entrar na relação de aliança, apresentando as estipulações da aliança no Sinai.

\subsection{DEUTERONÔMIO COMO UM TRATADO DE ALIANÇA SEGUNDO O MODELO DE TRATADO ENTRE SUSERANO E VASSALO}

Há diversas posições sobre autoria, datação e estrutura de Deuteronômio. Apesar de não ser o foco deste trabalho se aprofundar em tais discussões, é imperativo discorrer sobre quais são elas para dar prosseguimento. Basicamente, são quatro os enfoques principais de Deuteronômio. O primeiro grupo é formado por aqueles que ainda preferem seguir a antiga posição de Julius Wellhausen $(1883)^{29}$ de que as crenças pactuais de Israel só passaram a ser um conceito dominante quando ocorreu a reforma religiosa de Josias e, para servir de referência, o Deuteronômio teria sido escrito, como é o caso de Nicholson (1986). O segundo grupo consiste naqueles que defendem que, no início, o Deuteronômio era apenas um antigo código legal que posteriormente recebeu acréscimo de elementos de aliança e tratado, como pensa

\footnotetext{
${ }^{28}$ Sitz im Leben - palavra alemã que literalmente significa "situação da vida". Esta expressão remonta a Hermann Gunkel (1862-1932), cf. Diccionario Teológico Enciclopédico, Verbo Divino, Navarra, 1995.

${ }^{29}$ WELLHAUSEN, J. Prolegomena to the Ancient Israel. Gloucester: Peter Smith, 1883, p. 417-420.
} 
Mayes (1981). ${ }^{30}$ Já o terceiro grupo é composto por diversos autores, incluindo Mendenhall (1954) e Weinfeld (1991), que defendem a ideia de uma redação pós-mosaica do Deuteronômio, mas que o livro possui um material bastante antigo que, por sua vez, reflete o formato de um tratado hitita ou assírio. ${ }^{31}$ Por fim, o quarto grupo é formado por autores mais tradicionais, como Kline (1963) e Craigie (1976), que entendem que os dados históricos e canônicos sugerem uma datação do II milênio a.C., fundamentados nas semelhanças com os tratados hititas entre suserano e vassalo. Apesar de todas as diferenças entre esses estudiosos, há alguns aspectos comum a todos eles. A maior parte deles destaca que há marcas significativas registradas pelos ideais da aliança entre YHWH e o povo de Israel no livro de Deuteronômio, assim como concorda sobre a teologia básica apresentada no livro. Sobre essa questão, P. House (1998, p. 215) diz:

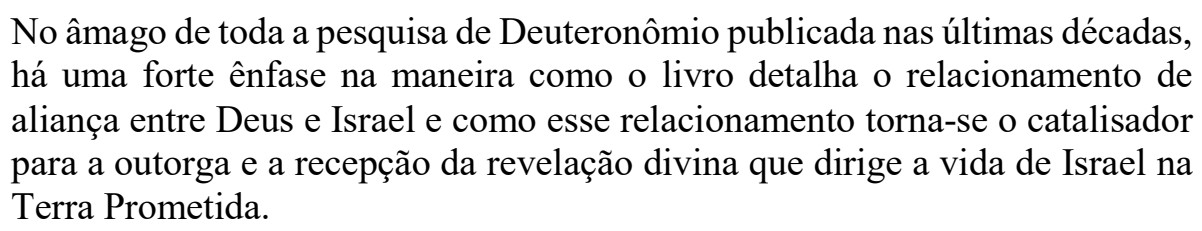

Entretanto, como já foi citado que não é o foco deste trabalho se estender nesse assunto, e tendo em vista o amplo consenso entre os estudiosos acerca da natureza pactual de Deuteronômio, apenas nos concentraremos em estabelecer as ligações entre o livro e os tratados entre suseranos e vassalos do Antigo Oriente Próximo; nesse caso, optamos pelo tratado hitita, devido aos maiores pontos de semelhança, além de serem os documentos mais bem preservados de todos os tratados de suserania da região. É possível que até mesmo os tratados assírios sejam um desdobramento tardio dos tratados hititas. Além disso, há também evidências comparativas suficientes indicando que os tratados hititas eram um padrão bastante utilizado em todo o Antigo Oriente Próximo (THOMPSON, 1964, p.13). Confirmando essa hipótese, Mendenhall (1954) concluiu em sua tese baseada no trabalho de V. Korošec (1931), propondo que "a analogia mais próxima ao decálogo e à aliança do Sinai se encontraria nesses tratados hititas de suserania que datavam aproximadamente de 1400 a 1100 a.C." (CLEMENTS, 1989, p. 314) 32.

É significativo entender que o objetivo principal de todo tratado de suserania era garantir os interesses do grande rei suserano e a lealdade do vassalo. De modo geral, os tratados eram

\footnotetext{
${ }^{30}$ MAYES, 1981, p. 29-55.

${ }^{31}$ Ver discussão mais aprofundada em MENDENHALL, George E. Covenant forms in Israelite tradition, BA 17, p.50-76; também em The suzerainty treaty structure: thirty years later, VT 41, p.85-100.

32 DAVIDSON, Robert. Ideologia da aliança no Israel Antigo. In: CLEMENTS, 1989, p. 314
} 
de natureza unilateral, mas parece que no caso dos hititas havia alguma possibilidade de deliberação positiva ou negativa ao convite de selar o tratado por parte do vassalo, mas podendo incorrer em consequências terríveis para ele; em contrapartida, ele ainda recebia a promessa de auxílio em situações de perigo e de bênçãos dos deuses pela lealdade na prestação de serviços. Já o caso dos assírios era bem diferente, não havendo nenhuma regalia, nem possibilidade de escolha, além disso, estavam sujeitos às ameaças de visitação divina trazendo maldições em caso de infidelidade (KOROŠEC, 1961, p. 274). No que diz respeito às estipulações do tratado, eram definidos unicamente pelo suserano, sem qualquer consulta ao vassalo que simplesmente deveria prestar obediência. Com essa compreensão, é pertinente conhecer ao menos a estrutura "padrão" do tratado entre suserano e vassalo do Antigo Oriente Próximo:

1. O preâmbulo - que identifica o nome e títulos do soberano, estabelecedor do tratado, que se abre com a seguinte fórmula: "Assim (fala) [...], o grande rei, o rei de X [...]" (BRIEND, 1985, p. 58);

2. O prólogo histórico - é a razão de ser do tratado, em que os acontecimentos relevantes e as relações passadas entre as duas partes do tratado são esboçadas e relembradas; mostrando principalmente os benefícios que o vassalo já recebeu do suserano, inspirando com isso a gratidão, lealdade e obediência da parte do vassalo;

3. As estipulações ou condições do tratado - basicamente, são práticas que exigem lealdade absoluta do vassalo ao seu suserano:

(a) Condições gerais - são os princípios básicos do relacionamento; revelam os propósitos do grande rei e alertam o vassalo quanto às linhas mestras pelas quais deveriam executar esses propósitos;

(b) Estipulações específicas - detalham as estipulações gerais, abordando questões concretas e servindo como orientação complementar através de casos particulares previstos pelo rei;

4. As sanções do tratado, bênçãos e maldições - definem as consequências da fidelidade e da desobediência ao tratado, respectivamente; as maldições eram a destruição total para os que violassem o tratado; 
5. As testemunhas - fazem referência aos deuses que garantirão o tratado, que testificam o valor e o compromisso firmado pelas partes do tratado.

Além desses elementos básicos, era comum ter uma cláusula sobre o depósito do documento no santuário para uma leitura pública periódica, além de uma cerimônia religiosa, muitas vezes com sacrifícios de sangue, em que o tratado era homologado (WISEMAN, 1958, p. 28). É interessante notar que Mendenhall (1954) também incluiu esse mesmo elemento em sua lista, adaptando-o ao ambiente do templo.

A fim de se ter um exemplo mais palpável de um típico tratado hitita entre suserano e vassalo, vamos considerar o tratado entre Muršiliš II (1339-1306 a.C.) e Duppi-Tě̌šsb de Amurru (PRITCHARD, 1958, P.203-205). ${ }^{33}$ É interessante ter em mente o Deuteronômio para acompanhar e perceber as semelhanças.

\section{Preâmbulo}

Estas são as palavras do Sol Muršiliš, o grande rei, o rei da terra de Hatti, o valente, o favorito do Deus-Tempestade, filho de Suppiluliumas, o grande rei, o rei da terra de Hatti, o valente.

\section{Prólogo histórico}

Aziras, o seu avô Duppi-Teššub, se rebelou contra o meu pai, mas se submeteu novamente. Quando os reis da terra de Nuhassi e os reis de Kinza se rebelaram contra o meu pai, Aziras não se rebelou. Assim como ele estava sujeito ao tratado, permaneceu sujeito pelo tratado [...] Aziras permaneceu leal ao meu pai e não incitou a ira de meu pai. [...]

Quando meu pai se tornou deus e eu me assentei ao trono de meu pai, Aziras foi fiel a mim do mesmo modo que foi ao meu pai. [...]

Quando seu pai morreu, eu não o abandonei como foi pedido pelo seu pai. Desde que seu pai mencionou o seu nome com grande alegria, procurei por você. Certamente, você estava muito doente, mas mesmo assim, eu, o Sol, o coloquei no lugar de seu pai e tomei seus irmãos e irmãs e a terra de Amurru em honra ao tratado com você.

\section{Princípios gerais para a conduta futura}

[...] Por isso, honre o juramento (de lealdade) ao rei e aos parentes do rei. E eu, o rei, serei leal para com você, Duppi-Teššub. Quando você tomar uma esposa, e quando você gerar um herdeiro, ele será rei na terra de Amurru. E assim como eu devo ser leal a você, serei leal para com o

\footnotetext{
${ }^{33}$ Esse texto é uma tradução nossa do trabalho de Pritchard.
} 
seu filho. Mas você, Duppi-Teššub permaneça leal ao rei da terra de Hatti [...] Não olhe para mais ninguém.

\section{Estipulações específicas}

Você deve ser amigo dos meus amigos, e inimigo dos meus inimigos [...]

Como eu, o Sol, sou leal a você, você deve prestar ajuda militar ao Sol e à terra de Hatti $[. .$.

Se alguém o pressionar, Duppi-Teššub, ou se alguém se revoltar contra você, logo você deve escrever ao rei da terra de Hatti e ele enviará soldados e cavaleiros em seu auxílio - e (se você os tratar com injustiça), você viola seu juramento.

Se algum deportado da terra de Nuhassi [...] escapar e for até você, se você não o receber e mandar de volta ao rei da terra de Hatti $[. .$.$] você$ viola seu juramento.

Se alguém pronunciar palavras hostis contra o rei da terra de Hatti diante de Duppi-Teššub, você não deve ocultar o nome dele do rei.

$[\ldots]$

\section{Testemunhas divinas}

O Deus-Tempestade do Céu, a Deusa-Sol de Arinna, o DeusTempestade do Céu, o Deus-Tempestade de Hatti, Seris e Hurris, Monte Nanni e Monte Hazzi [...]

Sin, senhor do juramento, Ishara, rainha do juramento, Hebat, rainha do céu, Ishtar, Ishtar do campo de batalha, Ishtar de Nínive [...]

[...] os deuses e deusas da terra de Hatti, os deuses e deusas da terra de Amurru, todos os deuses antigos, Naras, Napsaras, Minki, Tuhusi, Ammunki, Ammizadu, Allalu, Anu, Antu, Apantu, Allil, Ninlil, as montanhas, os rios, as nascentes, o grande Mar, céu e terra, os ventos e as nuvens - sejam testemunhas desse tratado e do juramento.

\section{Maldições e bênçãos}

As palavras do tratado e do juramento que estão inscritos aqui - se Duppi-Teššub não honrar essas palavras do tratado e do juramento, esses deuses destruirão Duppi-Teššub, sua esposa, seu filho, seu neto, sua casa, sua terra, e com tudo o que ele possui.

Mas se Duppi-Teššub honrar essas palavras do tratado e do juramento que estão inscritos aqui, esses deuses o protegerão, sua esposa, seu filho, seu neto, sua casa e seu país. 


\subsection{UMA COMPARAÇÃO ENTRE O DEUTERONÔMIO, O LIVRO DA ALIANÇA, COM OS TRATADOS HITITAS}

Para fazer a comparação dos tratados hititas com a BH, Kline e Craigie, estudiosos que e propõem e ressaltam a unidade do Deuteronômio escrito conforme o padrão dos antigos tratados de suserania, interpretam todo o livro dentro do contexto da aliança redentora de YHWH com Israel, resultando no seguinte esboço (KLINE, 1963, p. 7-8):

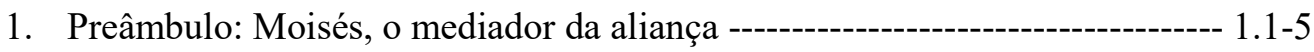

2. O prólogo histórico; a história da aliança ---------------------------------- 1.6 - 4.49

3. As estipulações da aliança: a vida sob a aliança
a. $\mathrm{O}$ grande mandamento
$5.1-11.32$
b. Mandamentos subsidiários $12.1-26.19$

4. As sanções da aliança:

ratificação da aliança, bênçãos e maldições e voto de confirmação da aliança $-27.1-30.20$

5. Disposições dinásticas: continuidade da aliança $31.1-34.12$

Desse modo, é possível ter uma visão de Deuteronômio como um tratado de aliança, segundo os moldes do Antigo Oriente Próximo. No entanto, o texto de Deuteronômio não segue exatamente os padrões propostos. Há disposições distintas, apesar de ter uma estrutura geral bastante similar aos tratados em questão. Podemos destacar, por exemplo, o texto de Deuteronômio 1.1-5, que não caracteriza exatamente o preâmbulo típico, pois quem fala é Moisés na qualidade de mediador e não YHWH. A apresentação do grande rei suserano, YHWH, aparece mais adiante, na introdução do Decálogo, em Deuteronômio 5.6:

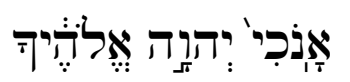

Eu sou o SENHOR, o teu Deus. 
O prólogo histórico lembra o acontecimento de Horebe, a vida no deserto e a conquista da terra prometida, referindo-se à própria história do povo e às lições aprendidas nessa jornada. Ele também é uma exortação a manter-se fiel a Deus, que guiou o povo desde os primeiros anos da sua existência, e está disposto em Deuteronômio 1.6 - 4.40 e também em Deuteronômio 5.6, conforme pode-se ler nos exemplos:

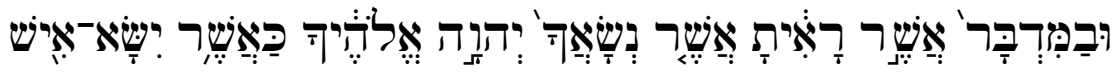

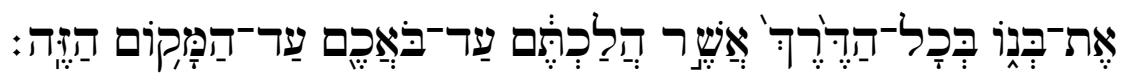

Também no deserto vocês viram como o SENHOR, o seu Deus, os carregou, como um pai carrega seu filho, por todo o caminho que percorreram até chegarem a este lugar. (Dt 1.31)

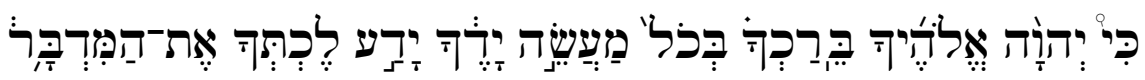

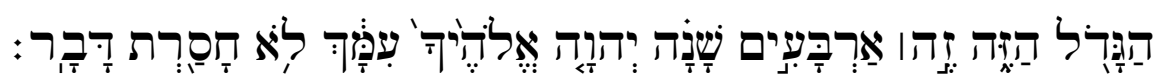

Pois o SENHOR, o seu Deus, os tem abençoado em tudo o que vocês têm feito. Ele cuidou de vocês em sua jornada por este grande deserto. Nestes quarenta anos o SENHOR, o seu Deus, tem estado com vocês, e não lhes tem faltado coisa alguma. (Dt 2.7)

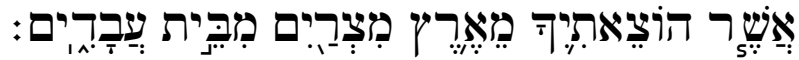

[...] que te tirei do Egito, da terra da escravidão. (Dt 5.6)

Os princípios básicos dessa aliança estão no texto referente ao Decálogo, além do primeiro e grande mandamento do "Shemá":

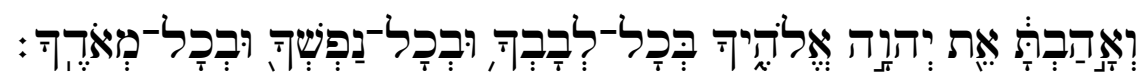

Ame o SENHOR, o seu Deus, de todo o seu coração, de toda a sua alma e de todas as suas forças. (Dt 6.5)

Já o campo das "estipulações específicas" seria mais adequado à utilização do termo "princípios suplementares da aliança", que se encontram na seção compreendida de Deuteronômio 7.1 - 11.32, como por exemplo: 


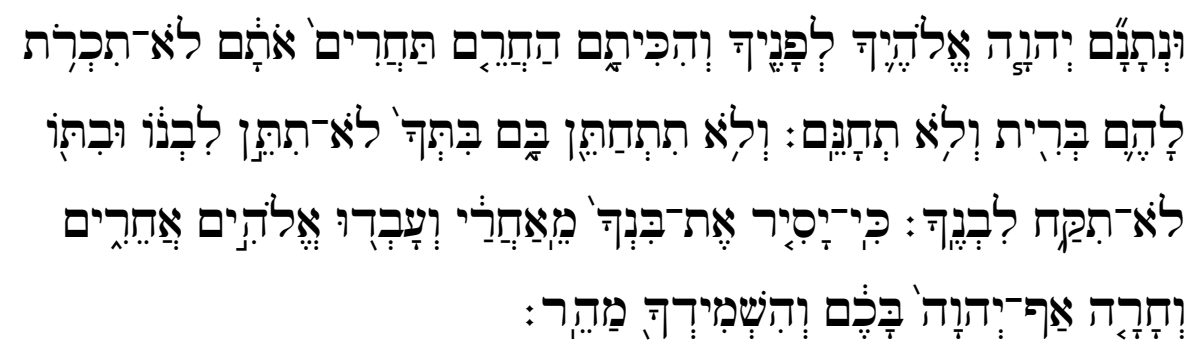

[...] e quando o SENHOR, o seu Deus, as tiver dado a vocês, e vocês as tiverem derrotado, então vocês as destruirão totalmente. Não façam com elas tratado algum, e não tenham piedade delas. Não se casem com pessoas de lá. Não deem suas filhas aos filhos delas, nem tomem as filhas delas para os seus filhos, pois elas desviariam seus filhos de seguir-me para servir a outros deuses e, por causa disso, a ira do SENHOR se acenderia contra vocês e rapidamente os destruiria. (Dt 7.2-4)

As bênçãos e maldições da aliança encontram-se bem definidas no texto de Deuteronômio 27.1 - 28.69, apesar de haver trechos espalhados pelo livro todo de tal conteúdo. Seguem um exemplo de cada, respectivamente:

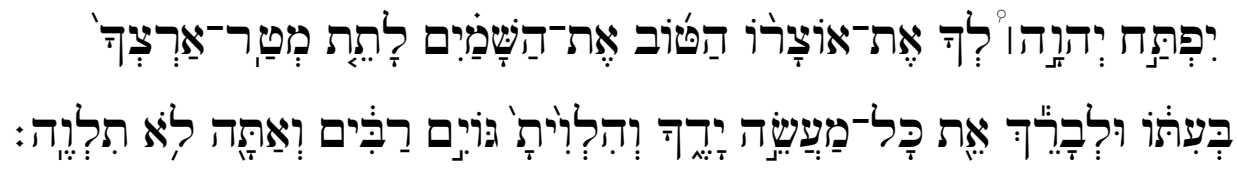

O SENHOR abrirá o céu, o depósito do seu tesouro, para enviar chuva à sua terra no devido tempo e para abençoar todo o trabalho das suas mãos. Vocês emprestarão a muitas nações, e de nenhuma tomarão emprestado. (Dt 28.12)

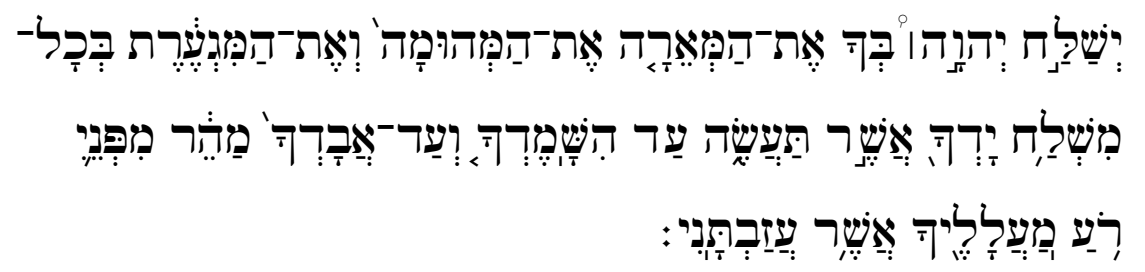

O SENHOR enviará sobre vocês maldições, confusão e repreensão em tudo o que fizerem, até que vocês sejam destruídos e sofram repentina ruína pelo mal que praticaram ao se esquecerem dele ${ }^{34}$. (Dt 28.20)

${ }^{34}$ Dt 28.20 - Hebraico: de mim. 
E, por fim, a testemunha é o próprio livro da Lei, ${ }^{35}$ confiado aos levitas, conforme está exposto em Deuteronômio 31.24-27:

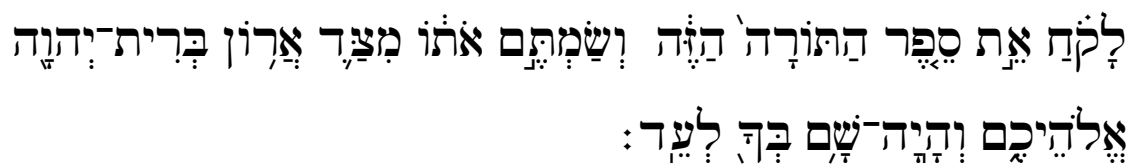

Coloquem este Livro da Lei ao lado da arca da aliança do SENHOR, do seu Deus, onde ficará como testemunha contra vocês. (Dt 31.26)

\subsection{A LINGUAGEM DA ALIANÇA}

É bastante interessante que a aliança na BH não envolve apenas um conceito próprio, mas também um vocabulário peculiar. Por exemplo, o estabelecimento de uma aliança envolve uma ação que no hebraico é "cortar", formando a expressão aliança", que na realidade significa "fazer aliança", ou simplesmente "estabelecer um contrato" trazendo para os dias de hoje. No entanto, essa expressão é repleta de conteúdo teológico. Uma aliança tem de ser "cortada", porque, segundo Speiser (1963, p. 112), o ato de "cortar" um animal, fazendo um sacrifício de sangue, era parte do ritual da aliança. Um episódio que ilustra bem esse ato é o texto de Gênesis 15.17-18a, no qual YHWH fez ("cortou") uma aliança com Abrão: "Depois que o sol se pôs e veio a escuridão, eis que um fogareiro esfumaçante, com uma tocha acesa, passou por entre os pedaços dos animais" (Gn 15.17);

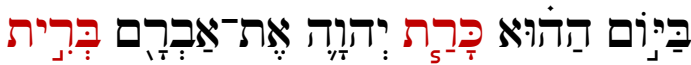

Naquele dia o SENHOR $f e z$ a seguinte aliança com Abrão. (Gn 15.18a)

$\mathrm{Na}$ opinião aceita por muitos intérpretes da época de Rashi, esse ritual um tanto misterioso é o mesmo que dizer: "que a sorte que caiu sobre o animal caia sobre ele, caso não guarde $b^{e} r i ̂ t$ ”; isso pode ser confirmado em um documento do século VIII que diz: "Assim como

\footnotetext{
35 Essa concepção é mais tardia do que a de Js 24.27: "Vejam esta pedra! Ela será uma testemunha contra nós, pois ouviu todas as palavras que o SENHOR nos disse.”, conforme J. Briend, 1985.
} 
este bezerro é cortado em pedaços, seja Mati'el também cortado em pedaços” (DITAT, p. 751$752) .{ }^{36}$

Da mesma forma, também foram realizados diversos estudos linguísticos que comprovaram que os tratados do Antigo Oriente Próximo do segundo e primeiro milênios a.C. fornecem informações valiosas sobre a linguagem utilizada para expressar os tratados que selavam a relação entre suserano e vassalo, encontrando muitas semelhanças na $\mathrm{BH}$.

Há, em primeiro lugar, muitos termos etimologicamente equivalentes, já que a maioria dos tratados do Oriente Próximo eram escritos em acadiano e aramaico, idiomas cognatos do hebraico bíblico. Por exemplo, o termo $s^{e}$ gullah utilizado para descrever Israel como o "tesouro pessoal" de YHWH na BH é equivalente ao acadiano sikiltu do tratado de Alalah usado para descrever o rei como um "tesouro pessoal" de deus.

Para facilitar a visualização desses paralelos, segue uma lista com os respectivos equivalentes e significados:

Tabela 1

\begin{tabular}{|c|c|c|}
\hline Hebraico & Equivalente Acadiano & Significado \\
\hline 'ābhar b rît & māmìt / niš ilāni etēqu & $\begin{array}{l}\text { "transgredir a aliança" (Heb.)/ } \\
\text { "transgredir o tratado dos deuses" }\end{array}$ \\
\hline$d^{e} b \bar{a} r \hat{\imath} m$ & awāte & $\begin{array}{c}\text { "palavras" (ambos definem as } \\
\text { estipulações da aliança) }\end{array}$ \\
\hline$\check{s}^{e} b \hat{u}^{\prime} \bar{a} h$ & māmītu & "juramento" \\
\hline 'ālāh & aratu & "maldição" \\
\hline yāššr, mēšarim, mîš̂or & mēšarum & "justiça" ou "retidão" \\
\hline$h a \bar{a} t \bar{a}$ '(v) e hațtā' $(\mathrm{s})$ & $h a t \underline{u}(\mathrm{v}), \operatorname{hit} u(\mathrm{~s})$ & $\begin{array}{l}\text { literalmente significam "pecado", } \\
\text { mas usados para definir uma } \\
\text { rebelião contra o suserano }\end{array}$ \\
\hline
\end{tabular}

É significativo destacar que até um termo como "amor" que sempre representou uma singularidade da aliança entre YHWH e Israel tem paralelo linguístico no mundo antigo.

\footnotetext{
36 Sefireh, I, A. In: DITAT, kārat, p.751-752.
} 
Descobriu-se que há equivalente semântico nos tratados do Oriente Próximo, uma vez que se esperava que tanto suseranos como vassalos demonstrassem certo grau de devoção um pelo outro, mesmo que isso significasse apenas uma formalidade. No entanto, não existe nada que se compare ao hesed YHWH, o "amor leal da aliança" ou "fidelidade à aliança, que denota uma "profundidade de compromisso pessoal na relação de aliança que envolve os participantes em obrigações que se estendem muito além do que poderia ser estabelecido formalmente como estipulações de um tratado" (THOMPSON, 1982, p. 38). Na BH, é possível verificar que há uma ênfase acentuada em conceitos como perdão, misericórdia e graça da parte de YHWH para com o seu povo, elementos que não são encontrados em nenhuma outra relação de suserania do Oriente Próximo. Tais características peculiares fazem parte do caráter de YHWH e, por isso, são únicos na sociedade do tipo feudal do Oriente Próximo. Por essa razão, um estudo comparativo do vocabulário dos tratados demonstra, segundo o acadêmico australiano J. A. Thompson (1982), que Israel tinha um jeito próprio de descrever a aliança entre YHWH e seu povo, utilizando o vocabulário que expressasse adequadamente o caráter único dessa aliança com o seu Deus.

\subsubsection{A LINGUAGEM ABRANGENTE DA ALIANÇA EM DEUTERONÔMIO}

O termo $b^{e}$ rît ocorre pelo menos 27 vezes em Deuteronômio, que trata da renovação da aliança no Sinai com a segunda geração de israelitas, sobreviventes das peregrinações no deserto, antes de entrarem na terra de Canaã. É provável que gerações sucessivas de israelitas tenham usado o material do livro como um documento de renovação da aliança até a época da reforma de Josias e depois dela (29.14-15). No entanto, a linguagem da aliança não se restringe ao uso do termo $b^{e}$ rît. Há um conjunto mais amplo que compõe tal linguagem. Nesse sentido, uma infinidade de artigos, ensaios e livros têm sido escritos sobre a "fórmula da aliança", como desenvolvimento de uma metodologia crítica, e é nesse contexto que Rendtorff (1998), antes de mais nada, identifica Hermann Gunkel como o criador da crítica da forma e da metodologia de "isolar fragmentos textuais, muitas vezes tão pequenos que ficam totalmente fora do seu contexto" (RENDTORFF, 1998, p. 9). 
Nesse contexto, Rendtorff faz uma investigação inovadora e interessante. Ele observa que há uma "fórmula" que se repete quando se trata da estrutura da aliança: "Eu serei o seu Deus e vocês serão o meu povo", que apesar de muitas vezes não estar diretamente ligada à palavra $b^{e}$ rît, faz parte das estipulações inerentes a ela. Ele aponta para Smend (apud RENDTORFF, 1998, p. 9) ${ }^{37}$ como o primeiro a investigar esta fórmula no contexto de Deuteronômio 26.16-19, concluindo que essa é a origem da renovação da aliança por Josias registrado em 2 Reis 23.

Prosseguindo nos estudos de Rendtorff, ele começa sua análise dessa fórmula, observando que ela ocorre em três diferentes formas:

(1) "Eu serei (sou) o seu Deus", com 16 ocorrências;

(2) "Vocês serão (são) o meu povo", com 10 ocorrências;

(3) a combinação de ambas em uma única sentença, com 16 ocorrências (RENDTORFF, 1998, p. 13).

Ao fim de sua análise, ele conclui que os quatro primeiros livros do Pentateuco geralmente fazem uso da primeira forma, duas vezes da terceira, mas nunca utilizam a segunda. Enquanto que no livro de Deuteronômio há uma inversão, pois utiliza a segunda forma com frequência, a terceira duas vezes, e a primeira é quase ausente. Essa "fórmula da aliança" também se repete com alguma frequência em partes nos livros proféticos, especialmente em Jeremias e Ezequiel, mas quase sempre em sua terceira forma, combinada, o que indica que os diversos escritores bíblicos têm um olhar distinto de como Deus e Israel se relacionam entre si, mesmo que eles tenham uma linguagem da aliança comum.

Ainda em seu trabalho, Rendtorff atribui significado teológico aos mínimos detalhes e variações na escolha das palavras e da ordem das palavras em cada uma das três formas propostas. Por exemplo, ele tenta explicar a diferença na ordem de palavras entre Jeremias 7.23 e 11.4, em que usam a terceira forma com ordens trocadas: enquanto Jeremias 7.23 começa com "eu serei o seu Deus", Jeremias 11.4 começa com "vocês serão o meu povo". Parece carregar um certo tom de exagero, podendo ser um exemplo da tendência moderna de encontrar "fórmulas" para tudo, criando a necessidade de explicar todos os desvios de um suposto padrão

\footnotetext{
37 SMEND, Rudolf, Die Bundesformel, 1963. Na citação, Rendtorff traz uma nota sobre a boa receptividade da nomenclatura "fórmula da aliança" de Smend.
} 
proposto. No entanto, por outro lado, é bastante válida a posição do estudioso alemão de que, muitas vezes, a erudição tem fragmentado o texto bíblico, pois estudam os termos bíblicos de modo totalmente isolado do seu contexto sem compreender o todo.

Por que, então, essa conclusão é relevante para a presente pesquisa? Justamente porque é possível detectar que a aliança é o tema orientador do livro de Deuteronômio; apesar de nem sempre estar diretamente vinculado ao termo $b^{e}$ rît, há toda uma "linguagem da aliança" que permeia o texto.

Seguindo esse raciocínio e entendendo a existência dessa linguagem da aliança, que se define na relação em que YHWH é o Deus de Israel, e este, o povo de YHWH, pretendemos aplicar esses conceitos ao presente trabalho. Aqui, é bastante valioso destacar a frequência elevada do uso de um termo temporal hayyôm, "hoje", no contexto da aliança em Deuteronômio, cuja importância teológica foi observada primeiramente e registrada por Gerhard von Rad em suas obras ${ }^{38}$. Ele explica que os requisitos específicos da vida sob a aliança estão agora reunidos de forma simplificada como um guia claro para o presente e também para um futuro instável. E a escolha é de Israel - imediato, irrevogável e inevitável: "Hoje invoco os céus e a terra como testemunhas contra vocês, de que coloquei diante de vocês a vida e a morte, a bênção e a maldição. Agora escolham a vida, para que vocês e os seus filhos vivam" (Dt 30.19).

Dessa forma, neste capítulo, vimos que o livro de Deuteronômio apresenta o que é digno de ser chamado "Livro da Aliança", pelo seu conteúdo e vocabulário peculiar que denotam a íntima relação com os tratados de aliança do Antigo Oriente Próximo.

Mais adiante, no próximo capítulo, faremos uma análise do termo הִָּ (hayyôm), que significa "hoje", apresentando centenas de ocorrências na $\mathrm{BH}$, mas também porque é impressionante que haja um número tão elevado de ocorrências ${ }^{39}$ concentrado no livro de Deuteronômio. Explicaremos, ainda, de forma mais detalhada o significado e a função desempenhada por essa palavra tão importante em Deuteronômio, além do resultado alcançado pelo uso do mesmo.

\footnotetext{
${ }^{38}$ Primeiro em sua Deuteronomium-Studien, mais tarde, em Das form-geschichtliche Problema des Hexateuchs e, finalmente, em sua obra magistral, Theologie des Alten Testaments.

${ }^{39}$ Há 58 ocorrências em Deuteronômio, cf. WOLFF, 2007, p.146.
} 


\section{O PAPEL DO HAYYÔM}

\subsection{A CONCEPÇÃO DE "HISTÓRIA" COMO EXPERIÊNCIA TEMPORAL DIFERENCIADA DO POVO DE ISRAEL NA BH}

A história da salvação é Historie ou Geschichte? Essa é uma pergunta decorrente da pesquisa bíblica feita no contexto de fala alemã. No contexto germânico, Historie é a História como transmissão de fatos brutos sem interpretação e Geschichte é a história interpretada (LOHFINK, 1984, p. 89). Muitos estudiosos continuam a debater sobre a diferença entre a história da $\mathrm{BH}$ como história de Israel e a reconstrução de tal história feita pelos estudiosos críticos modernos. Como relacionar a história “objetiva”, ou pelo menos seus aspectos sóciopolíticos e a história teologicamente orientada da BH? É necessário haver uma combinação entre o conceito teológico e o fato histórico, pois segundo Goldingay, os "fatos sem palavras [interpretação] são cegos; palavras sem fatos são vazias" (GOLDINGAY, 1981, p. 77). Nesse sentido, deve-se admitir que os fatos da $\mathrm{BH}$ são interpretados, uma vez que os autores descrevem os acontecimentos que envolvem Deus, o povo e o mundo; enquanto que os historiadores do século XIX só consideraram História aquilo que era passível de ser documentado e confirmado através de métodos científicos, descartando qualquer ação de Deus como parte integrante da história (LEMKE, 1982, p. 41).

Diante dessa distinção, devemos admitir que os autores da $\mathrm{BH}$ e os historiadores modernos realmente têm pressuposições diferentes. Mas, apesar desse distanciamento e da polarização entre os dois enfoques, vale considerar o que um reconhecido estudioso da $\mathrm{BH}$ afirmou: "Hoje não temos um bom motivo para duvidar de que há uma dose significativa de congruência entre os verdadeiros fatos da história de Israel reconstruídos pela crítica e o modo pelo qual são lembrados em suas tradições sagradas". (LEMKE, 1982, p. 45-46). No entanto, ler a BH é ler a história orientada, e isso precisa estar sempre em mente. Conforme asseverou Von Rad, Heilsgeschichte é uma história formada e movida pela palavra de Deus, que é uma palavra de julgamento e salvação injetada nela, movendo-a para a realização final.

A partir dessas importantes considerações, tentaremos compreender melhor o conceito de história apresentada na Bíblia Hebraica que delineia uma experiência temporal única e 
completamente diferenciada.

Com base na discussão sobre o conceito de tempo na $\mathrm{BH}$ discorrida no capítulo primeiro, pode-se perceber que Israel não conhecia uma noção do tempo absoluto, existente por si só. Não havia condições naquele contexto de se pensar no tempo de forma abstrata e independente dos respectivos acontecimentos. No entanto, Israel conhecia um "tempo já preenchido" (VON RAD, 2006, p. 534). Considerando os termos que expressam o tempo na BH já citados, fica claro que todo acontecimento obedece a uma ordem determinada do tempo, não havendo possibilidade de conceber um acontecimento sem seu tempo, nem um tempo sem seu acontecimento (MARSH, 1952, p. 27). Isso parece fazer sentido quando se trata da natureza, do seu ciclo e ritmo, mas os antigos entendiam que essa mesma ordem também se aplicava a todo tempo humano, inclusive aos sentimentos e emoções, porque tudo o que está abaixo do céu tem o seu devido tempo עת ('êt), como diz claramente em Eclesiastes 3.1-11:

Para tudo há uma ocasião certa; há um tempo certo para cada propósito debaixo do céu:

Tempo de nascer e tempo de morrer, tempo de plantar e tempo de arrancar o que se plantou,

tempo de matar e tempo de curar, tempo de derrubar e tempo de construir, tempo de chorar e tempo de rir, tempo de prantear e tempo de dançar, tempo de espalhar pedras e tempo de ajuntá-las, tempo de abraçar e tempo de se conter,

tempo de procurar e tempo de desistir, tempo de guardar e tempo de jogar fora,

tempo de rasgar e tempo de costurar, tempo de calar e tempo de falar, tempo de amar e tempo de odiar, tempo de lutar e tempo de viver em paz [...]. Ele fez tudo apropriado ao seu tempo. Também pôs no coração do homem o anseio pela eternidade.

A despeito da singularidade literária de Eclesiastes, deve ficar claro que essa percepção profunda não é exclusiva do Qohelet, mas sim um dos pensamentos inerentes ao contexto da época. Apesar de se reconhecer que através dessa ordem e desígnio, Israel experimentava o "tempo" de um modo distinto da concepção linear que vai prevalecer no pensamento ocidental, também é possível reconhecer expressões que remetem ao passado. É possível, por exemplo, fazer a ligação de acontecimentos no tempo, como vemos na expressão ba 'êt hahî' (TLOT, p. 953), ${ }^{40}$ que equivale a bayyôm hah $\hat{u}$, "naquele tempo". De fato, muitas vezes, no contexto de

40 Cf. TLOT, o termo ocorre 52 vezes na Bíblia Hebraica, principalmente no Pentateuco, na História Deuteronômica e Crônicas, com esse sentido. 
Deuteronômio, bā 'ēt hahî̀' é utilizado para marcar o intervalo entre o 'attâ, "agora" ou hayyôm, "hoje" da pessoa que fala e o evento acontecido no passado do povo de YHWH.

Há também termos e expressões que marcam o presente vivido e o futuro cheio de conteúdo e significado, transformando essas experiências temporais em "história" pelos encontros com YHWH. Nesse ponto, podemos questionar: como o povo hebreu manteve sua identidade e sua fé "vivas" ao longo de tanto tempo? E como foi "formada" a sua história? A princípio, é importante ressaltar que todas as experiências do povo de Israel deviam ser lembradas e relembradas, sendo trazidas para o presente, a fim de preservar os elementos básicos de sua história, transmitindo-os de modo bem "vivo" de geração a geração. Sobre essa consciência histórica e existencial, Yerushalmi (1996, p. 9) declara: “O antigo Israel conhece a Deus pelo que ele fez na história. Dessa forma, a memória torna-se crucial para a sua fé e, em última instância, para a sua própria existência”.

Essa função tão fundamental era concretamente levada a efeito através dos $m \hat{o}^{` a} d \hat{\imath} m$, as festas que davam o ritmo da vida no tempo no antigo Israel. Antes de mais nada, é necessário procurar entender o que as festas sagradas representavam para pessoas que desconheciam a ideia de um tempo absoluto e linear, para as quais justamente essas festas eram os dados absolutos. Para elas, YHWH fizera "o dia" (hayyôm) como diz o Salmo 118.24: "Este é o dia que o SENHOR fez" "42. É por isso, por exemplo, que o sábado era um dia santificado, separado por YHWH e a comunidade participava do descanso de Deus. Do mesmo modo, a festa das tendas (das cabanas ou dos tabernáculos) era um tempo de alegria, estabelecido por YHWH, e todos, sem exceção, deveriam guardar esse tempo e relembrar como o povo de Israel viveu em tendas no deserto, após a libertação do Egito. Todas essas decorrências relacionadas aos $m \hat{o}^{a}{ }^{a} \mathrm{~d} \hat{\imath} m$, (tempos determinados ou designados) e seu significado não faziam parte de mero ritualismo, mas eram a base da fé dessa comunidade. E é com base nesse conceito que se deve entender toda a discussão sobre o tempo, mesmo com as mudanças ocorridas após o assentamento nas terras de Canaã, como explica Von $\operatorname{Rad}(2006$, p. 538, grifo do autor):

Primitivamente, o ritmo das grandes festas israelitas era determinado pela ordem natural do ano na Palestina. O calendário das festas de Israel é de origem cananeia. É como tal, portanto, expressão de uma religião agrícola que

\footnotetext{
41 Quando falamos de "história" aqui, estamos nos referindo ao Geschichte, a história interpretada; mais precisamente, ao Heilsgeschichte, "história da salvação", cujo protagonista é YHWH.

42 Versão Bíblia A21. É interessante observar a tradução da NVI: "Este é o dia em que o SENHOR agiu", que traz uma leitura diferente, tendo Deus como agente da história, mas ainda assim, é o dia que está sob o controle e soberania de YHWH.
} 
concebia a semeadura e a colheita como uma ação sagrada imediata. Todavia, o conteúdo dessas festas parece ter-se modificado já pouco tempo depois da imigração de Israel em Canaã, apesar de o povo ter-se tornado inteiramente agrícola. Por ocasião dos Massot, a festa do início da colheita da cevada, recordava-se a saída do Egito (Êx 23.15); e por ocasião da grande festa de outono e da vindima, recordava-se o tempo do deserto e de morar nas tendas de folhagem (Lv 23.42s). Israel "historicizou" essas festas que outrora eram puramente agrárias. Praticamente não será possível superestimar a importância dessas modificações de característica, fruto da capacidade realizadora de uma concepção do mundo e da existência totalmente própria.

Naquela época, provavelmente, os israelitas não tinham consciência do quanto eram distintos nem da força que possuíam pelo fato de reconhecerem os acontecimentos históricos como seu fundamento; pois desse modo, passam a ter todas as razões para se falar de uma fundamentação histórica da fé em YHWH, uma vez que os atos históricos, através dos quais YHWH fundou o seu povo, eram, por assim dizer, absolutos.

Além disso, esses acontecimentos não permaneciam esquecidos no passado, mas estavam presentes para cada nova geração, não só como atualização espiritual do passado, mas, através dos ritos, essa comunidade realmente entrava na situação histórica de fato, como era determinado pelo respectivo mô 'êed. Quando eles celebravam a Páscoa, por exemplo, "em trajes de viagem, com o cajado à mão e sandálias nos pés, prontos para partir com pressa (Ex 12.11), fica claro que isso significava muito mais do que simplesmente recordar a saída do Egito" (VON RAD, 2006, p. 539). Eles realmente participavam daquele acontecimento de salvação e libertação. E, era dessa forma que eles compreendiam sua existência histórica, isto é, que um desenvolvimento, ou melhor, um processo histórico bastante complexo, baseado não só em um acontecimento, mas de toda uma série de atos de salvação da qual tinha surgido um "percurso histórico" precedia o seu presente. Provavelmente, houve um certo tempo em que os diversos fatos históricos eram celebrados independentemente um do outro e até em lugares diferentes. No entanto, bem mais tarde, o povo de Israel foi coordenando lentamente essas tradições numa série de acontecimentos sequenciais, passando a constituir um percurso histórico, tendo

aprendido a conceber que YHWH seguira um plano, que percorrera um longo caminho com os antepassados, até que nesse caminho Israel se tornara Israel. [...] elaborando para si uma história que é constituída exclusivamente da sequência de fatos que Deus designou para a salvação de Israel (Ibid., p. 541).

O fato é que essa concepção histórica de Israel se distancia muito da visão de mundo do Oriente Próximo antigo, que 
era marcada pelo pensamento circular mítico, por um esquema de reflexão que concebia o evento sagrado a partir do ritmo das ordens de cunho natural [...] Através do mito, elaboravam as experiências elementares de poder, com as quais se defrontava no âmbito da sua existência.(VON RAD, 2006, p. 545)

Essa concepção, porém, não bastava para formar a totalidade da história. Ainda que seja nítida a distinção entre o tempo sagrado israelita e o tempo cíclico, natural, presente em outras tradições do Oriente Próximo antigo, ainda faltava um elemento fundamental sobre o tempo perante Deus. Era preciso ter a noção de fim, um quadro escatológico, que somente foi alcançado com o livro de Daniel, segundo Von Rad. No entanto, ainda hoje, há uma discussão acirrada sobre o conceito de "escatologia" ${ }^{43}$, que foi utilizado primeiro e incluído como objeto de pesquisa científica de Gressmann $(1905)^{44}$, o que ocasionou também muitas controvérsias. Contra Gressmann, Mowinckel (2002) ${ }^{45}$ explica que a escatologia dos profetas está baseada no culto israelita, especialmente na entronização de YHWH (ex. Salmo 24), mas só se encontra na profecia bem tardia. Da mesma forma, G. Fohrer $(2006)^{46}$ também considera as predições que tratam de acontecimentos que ocorrem "no tempo" como não escatológicas. Mas, no final das contas, todas essas considerações nos fazem questionar se a própria "noção de tempo" não era estranha aos profetas.

De qualquer forma, houve uma mudança com os profetas na compreensão de um novo modo de atuação de Deus na história. A mudança foi que para o povo de Israel, a história havia se rompido com a vinda do juízo de YHWH sobre o pecado de Israel, e assim, sua existência passada estava selada e, a garantia da eleição, extinta. Por isso, a única salvação para Israel estava na nova atuação histórica de YHWH, na qual ele daria início a um tempo completamente novo para seu povo. Esse é o caminho da transição da profecia para a apocalíptica. E a característica principal desta mensagem profética é a retomada da tradição da eleição definida por uma expectativa iminente da ação de YHWH, que entendia que aquilo que se esperava estava próximo. No entanto, essa esperança é crucial, pois tudo o que é decisivo para a existência de Israel, depende agora de um evento futuro de Deus, no yôm $Y H W H$, "dia de YHWH”. Desse modo, a pregação profética se torna escatológica somente no momento que

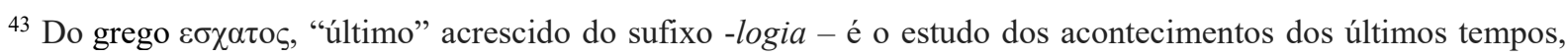
mais conhecido como "fim do mundo".

44 GRESSMANN, H. Der Ursprung der israelitisch-jüdischen Eschatologie. Göttingen: Vandenhoeck und Ruprecht, 1905.

${ }^{45}$ MOWINCKEL, Sigmund. The Spirit and the Word: Prophecy and Tradition in Ancient Israel. Fortress Classics in Biblical Studies. Minneapolis: Augsburg Fortress, 2002.

${ }^{46}$ FOHRER, G. História da Religião de Israel. São Paulo: Paulus, 2006.
} 
projeta Israel para fora da história salvífica passada, transferindo-a para um ato futuro de Deus, completando assim, o seu sentido histórico.

\subsection{O PAPEL DO HAYYÔM}

"Uma aliança é um acordo imutável e divinamente imposto entre Deus e o homem, que estipula as condições do relacionamento entre as partes" (GRUDEM, 1999, p. 425). É interessante fazer algumas observações sobre essa definição de aliança que reflete o agir divino para com Israel na BH. A primeira é que a aliança é "imutável”, o que quer dizer que uma vez estabelecida, não pode ser alterada; mas isso só é possível porque quem sustenta é YHWH, que é essencialmente imutável. A segunda, é que pressupõe o relacionamento entre duas partes, que na BH são YHWH e Israel. Nesse caso, o homem apenas responde em obediência e fé ao chamado daquele que tem o poder de "impor" as condições da aliança.

E essa fé no Deus da aliança guarda uma íntima relação com a sua "história", o que resulta na compreensão da sua relação diferenciada com o tempo. Como também já vimos, o próprio Deuteronômio considera a tradição do passado a partir de uma visão da "realidade da fé”. Mas o que isso quer dizer? Isso significa que a fé está baseada desde o princípio em algum dado da "história" e vive constantemente nela, constituindo assim o seu campo de atuação ${ }^{47}$; assim, é a vontade de YHWH que concebe e conforma a vida do povo e da sociedade; em outras palavras, é a ação divina que guia o presente e direciona o futuro da nação.

Seguindo essa linha de raciocínio, podemos entender a importantíssima ideia de como o "Deus da história" se torna o Deus moral e existencial através da apropriação do "tempo sagrado"; é ele que conduz à vivência ética, ao sentido existencial e à identidade como nação. Conforme R.G. Collingwood (1946, p. 282, 294), o passado nunca pode ser um fato apreendido empiricamente, e por isso, ele deve ser "redecretado" na mente de quem busca compreender e reviver o que já se passou. Nesse caso, a "apropriação" da tradição não requer que as gerações

\footnotetext{
47 A. Weiser chama a atenção sobre a permanente influência desta experiência histórica mediante o culto e a tradição.
} 
posteriores se projetem para o passado, ao contrário, elas devem fazer uma "atualização" ou trazer para o presente a tradição. Para melhor compreensão dessa "apropriação" é necessário nos atentarmos ao tipo de memória que o livro de Deuteronômio nos apresenta.

\subsubsection{MAIS QUE UMA SIMPLES MEMÓRIA}

Entre as mais diversas definições possíveis do termo memória, geralmente associado de forma imediata à ideia de lembrança ou reminiscência (com enfoque psicológico), merece destaque a de Pierre Nora: "a memória, ou o conjunto de memórias, mais ou menos conscientes de uma experiência vivida ou mitificada por uma comunidade, cuja identidade é parte integrante do sentimento do passado" (LE GOFF, 1978, p. 398). ${ }^{48}$ Como se pode observar, aqui está em vista a memória coletiva.

No entanto, não se pode entender o conceito de memória coletiva sem a compreensão do que é a memória em seu sentido primeiro. Um estudo bastante aprofundado sobre o assunto tem expressão delineada no pensamento do renomado pensador Henri Bergson $(2004)^{49}$ que publicou uma obra em 1896, na qual afirmava a existência de dois tipos de memória:

1) "Memória habitual", que é conscientemente impressa na mente através da repetição, o que a torna uma habilidade adquirida ou uma lição "aprendida de coração", sendo expressa no presente como um ritual ou liturgia recitada.

2) “Memória de imagem", que constitui a parte principal da consciência individual perceptiva e o lado subjetivo do conhecimento das coisas, sendo expressa por eventos únicos e irrepetíveis.

Posteriormente, em tempos mais recentes, o filósofo e hermeneuta francês Paul Ricoeur

\footnotetext{
48 A definição vem de "Mémoire collective", em LE GOFF, Jacques. La nouvelle histoire. Paris: Retz, 1978, p. 398.

49 Henri Bergson influenciou profundamente a análise da "memória" a partir de perspectivas filosóficas e psicológicas através de sua obra: Matter and Memory. NY: Dover, 2004.
} 
(2004 apud ELLMAN, 2013, p. 51) ${ }^{50}$ aprofunda e amplia a discussão sobre o assunto e discorre sobre o aspecto seletivo da memória coletiva. Ricoeur argumenta que, geralmente, as sociedades "escolhem" se lembrar de algumas coisas e esquecer de outras, o que conseguem fazer através de recitações e rituais comemorativos, que permitem institucionalizar o que deve ser lembrado. Não se pode deixar de destacar a percepção do egiptólogo Jan Assmann (2006) sobre a memória. Ele discute sobre como a memória cultural garante a manutenção da tradição no sentido da continuidade do significado, da visão de mundo e da própria identidade de geração a geração, através de ritos e textos, isto é, são eles que estabelecem e "transmitem o conhecimento confirmador da identidade narrando histórias que são compartilhadas" (ASSMANN, 2006, p. 37). Afinal de contas, uma nação é um povo com memórias e esperanças comuns. Sem elas, por mais numerosos e próximos que sejam um grupo de pessoas, continuam sendo apenas uma agregação, sem coesão e consciência nacional.

Considerando essa compreensão sócio filosófica contemporânea, devemos dizer que o texto de Deuteronômio (bem como a literatura deuteronomista) está baseado em memórias de uma nação, que são repetidas para que sejam "aprendidas de coração" e passadas adiante para as gerações seguintes através do ritual do culto. A memória narrativa serve como raiz a partir da qual Moisés dirige-se a Israel de forma convincente e didática. Do contexto da memória, a voz de Deuteronômio insiste em que Israel deve ponderar seu passado, para que no presente, ele possa ser plenamente obediente e, responsivamente, tornar-se povo de YHWH. Então, há elementos especiais quanto a essas memórias, pois não devem ser trazidas de modo passivo, mas possuem um significado bastante real e objetivo no presente. Nesse sentido, a intenção do retrospecto é tornar real e palpável a identidade distinta de Israel no presente para YHWH (BRUEGGEMANN, 2001, p. 25).

Essas "memórias" estão expressas no livro de Deuteronômio por um conjunto de vocabulário próprio, como: זכר (skr), "lembrar"; לבח (lb “coração". No contexto em questão, "lembrar" não se refere a um ato simplesmente mental ou psicológico, mas tem um propósito bem definido, e é diretamente proporcional ao ato de "fazer", mais precisamente, "cumprir" a todas condições propostas. Portanto, deve-se enfatizar aqui que elas são muito mais que simples memórias, pois "lembrar" é um mandamento dado pelo próprio YHWH a Israel, para que entendam o passado e obedeçam aos mandamentos

\footnotetext{
${ }^{50}$ RICOEUR. Paul. Memory, History and Forgetting. Chicago: University of Chicago Press, 2004.
} 
relacionados à aliança. Isso pode ser observado em diversos textos de Deuteronômio. ${ }^{51}$ Devese aqui destacar o capítulo 24: "Lembrem-se de que vocês foram escravos no Egito e de que o SENHOR, o seu Deus, os libertou; por isso lhes ordeno que façam tudo isso" (Dt 24.18, NVI, grifo nosso).

Em sua primeira acepção, a palavra "esquecer" traz consigo uma conotação negativa. Isso tem contornos específicos em Deuteronômio. Assim, de modo muito apropriado, Lambert definiu como motto deuteronômico a frase: "esquecer é perecer; lembrar é viver" (LAMBERT, 1976, p. 118). É muito interessante observar que, na grande maioria das vezes, em Deuteronômio, "esquecer" aparece na forma de uma negação expressa como: "não esqueça(m)", dando uma ênfase maior ao sentido da palavra "lembrar" (PANNELL, 2004, p. 21 ), como se pode ver em diversos textos do livro. ${ }^{52}$

$\mathrm{Na}$ antropologia do homem bíblico, "lembrar" ou "esquecer" tem relação direta com o “coração". Esse "coração" é uma parte importante para que essa memória especial seja realidade; pois esse "coração" é, ao mesmo tempo, órgão da intelecção e da volição humana. Segundo H. W. Wolff, "coração" na BH abrange tudo o que nós atribuímos à cabeça e ao cérebro: "a faculdade cognoscitiva, a razão, a compreensão, o entendimento, a consciência, a memória, o saber, a reflexão, o julgamento, a orientação e o juízo. Assim, fica definido o centro da significação genuína" (WOLFF, 2007, p. 96). É exatamente por essa razão que o povo deve amar a Deus "de todo o seu coração", quer dizer, integralmente; e também é a razão por que a obediência é provada no "coração" com base no conhecimento de Deus.

Mas, afinal de contas, qual é a importância de toda essa discussão sobre a memória coletiva especificamente aqui? O que há de peculiar nessa "memória do povo que se relaciona 'de coração' com YHWH? Há um elemento singular que merece atenção: o valor do que comumente é chamado de "memória" não está num passado distante que não tem nenhuma relação com a realidade atual, mas trata-se de uma verdade que tem existência e efetividade presente. Por isso, o texto de Deuteronômio 5.3 chama a quem está vivo, no momento presente, a viver e experimentar a aliança com YHWH, dizendo: "Não foi com os nossos antepassados que o SENHOR fez essa aliança, mas conosco, com todos nós que hoje estamos vivos aqui" (Dt 5.3).

\footnotetext{
${ }^{51}$ Ver referências em Dt 5.15; 8.2; 15.15; 16.12; 24.9, 18, 22.

${ }^{52}$ Ver referências em 4.9, 23, 31; 6.12; 8.11, 14; 26.13; 31.21.
} 
Portanto, a "memória" deuteronômica - que não é simples memória - é um instrumento explícito de manutenção da aliança. Essa memória cumpre dupla função: a primeira é de manter a verdade da aliança de YHWH sempre viva na mente de Israel, lembrando de sua parte nela; a segunda é de conectar os períodos históricos para que todas as gerações sejam absoluta e plenamente ligadas à aliança, do mesmo modo que a primeira geração nela entrou. Além do mais, a "memória" é crucial em Deuteronômio, porque sem ela, Israel se volta para a idolatria e apostasia. De fato, a condição padrão de Israel parece ser o esquecimento. Por isso, a voz em Deuteronômio incita repetida e continuamente o povo a "lembrar-se" dos feitos de YHWH. E dessa forma, fornece "um modelo para a transmissão da memória de uma geração para outra" (ELLMAN, 2013, p. 170).

No entanto, essa "memória" por si não é suficiente para cumprir esse papel. Por isso, há necessidade de entender como ela é transmitida através dos tempos, para que torne possível cumprir tais funções, conforme veremos a seguir.

\subsubsection{O HAYYÔM COMO LINGUAGEM DE “ATUALIZAÇÃO” DA ALIANÇA}

Como já vimos, é necessário que haja um instrumento capaz de unir o presente e o passado, tornando algo que faz parte do passado novamente vivo e real no presente. E após ter discorrido sobre o livro de Deuteronômio e as suas peculiaridades, podemos levantar o questionamento: por que foi tão necessário e vital para a comunidade de Israel conceber um escrito deuteronômico, se já existia o Êxodo, o "Livro da Lei”?

Naturalmente, a reflexão sobre essa questão precisa estar alicerçada em tudo o que já foi discutido aqui sobre a história e o tempo sagrado no antigo Israel. Afinal, não basta existir um acontecimento histórico, como foi o caso da entrega das leis por YHWH a Moisés no monte Sinai, ou a aliança selada entre YHWH e seu povo. O fato em si parece não ser suficiente. Pois, na medida em que surgem novas gerações, aumenta-se o abismo entre a nova geração e as anteriores, uma vez que as novas não conhecem realmente o poderoso YHWH e o seu amor alicerçado na aliança com seu povo, como seus antepassados. Então, é necessário que esse acontecimento seja relembrado e revivido para que tenha a mesma força e eficácia para cada 
nova geração, e não seja simplesmente esquecido, tornando-se apenas uma memória de um indivíduo qualquer e, portanto, "morta". E é justamente nesse ponto que o livro de Deuteronômio desempenha um papel primordial, pois justamente o foco do livro é tornar a tradição das gerações anteriores relevantes às gerações seguintes como um recurso para a continuação da vida como nação. Isso é possível graças à sua apresentação na forma de kerygma ${ }^{53}$, que permite "atualizar" os acontecimentos passados, "tornando-os atuais e reais ao momento em que se fala" ${ }^{\natural 4}$. Esse kerygma era a intencionalidade definida do deuteronomista em sua redação da história de Israel, dando-lhe sentido entre as gerações, sob a ação poderosa de YHWH. E foi exatamente por essa razão que Gerhard von Rad (2006) ${ }^{55}$ argumentou que a transmissão oral das tradições e da história do povo, de geração a geração, acaba por "unir" cada nova geração à geração anterior.

Neste ponto, surge uma valiosa questão: como foi possível transmitir tais realidades de modo vívido para as gerações seguintes? Há duas maneiras principais apresentadas em Deuteronômio. A primeira é que Israel recebeu a incumbência de "ensinar", estendendo a responsabilidade de ser e viver como povo de Deus para as gerações seguintes, tornando os fatos da história em realidades vívidas no presente. Pois, de certa forma, de acordo com o Deuteronômio, o modo de ser da vida de toda geração futura e o seu bem-estar dependem de como vive a geração atual; esta, tem o dever de ensinar e proclamar tudo que já conheceram sobre YHWH e seu amor (Dt 6.1-3). Assim, cada nova geração, confrontada com esse kerygma, torna-se participante contemporânea na Palavra de Deus e de suas demandas, como um "membro real" de Israel.

Por essa razão é pertinente destacar que Deuteronômio é o único livro do Pentateuco que usa o verbo "ensinar" (lamad) e procura falar insistentemente que isso deve ser feito a partir da unidade básica da sociedade: a casa. É a partir desse núcleo que a instrução e a obediência por amor a YHWH, deve reger a vida de todos que estão sujeitos à aliança com YHWH.

Ensine-as com persistência a seus filhos. Converse sobre elas quando estiver sentado em casa, quando estiver andando pelo caminho, quando se deitar e

\footnotetext{
53 Palavra grega que significa "proclamação" ou "pregação". O uso da palavra kerygma na BH foi adotado e difundido pelo estudioso alemão Gerhard von Rad em sua análise do Deuteronômio e, mais tarde, também, por Hans Walter Wolff.

${ }^{54}$ Definição de atualizar, atual, cf. dicionário português Michaelis.

${ }^{55} \mathrm{Na}$ realidade, essa proposta foi feita primeiro por Hermann Gunkel (1862-1932), em sua obra: Genesis. Göttinger Handkommentar zum Alten Testament I, 1.3rd ed. Göttingen: Vandenhoeck \& Ruprecht, 1910, e, mais tarde, von Rad ampliou o conceito a toda BH.
} 
quando se levantar. Amarre-as como um sinal nos braços e prenda-as na testa. Escreva-as nos batentes das portas de sua casa e em seus portões (Dt 6.7-9).

A segunda maneira como isso acontecia era através dos $m \hat{o}^{‘ a} d \hat{\imath} m$, que conforme já explicado, eram os tempos determinados por Deus, as festas cúlticas que determinavam o ritmo da vida de Israel. Nesses momentos especiais, o povo era chamado a reviver quase que de forma literal o passado, através da celebração, do culto e do kerygma. O estudioso B. Childs (1962) acredita que essa função do culto como meio de atualizar a tradição tenha entrado em um momento de crise da nação, sofrendo transformações mais tarde. Antes dessa hipótese, muitas foram as tentativas de relacionar Israel com seu passado apenas em termos de "memória" (CHILDS, 1962, p. 76).

Em pleno exercício da função querigmática, o texto de Deuteronômio direciona a audiência de "hoje" a "olhar", "ver" e desafia a "lembrar de ver" aquilo que não foi possível "ver" fisicamente, ou melhor, testemunhar. Isso quer dizer que os atos de YHWH podem ser "vistos" pelas gerações posteriores através da "apropriação" que vem pela "lembrança" deuteronômica.

Quando isso acontece, o passado se torna uma realidade presente no dia de "hoje". Assim, segundo Pannell, "na medida em que a tradição (passado) é testemunha da ação poderosa de YHWH, a realidade da tradição pode transformar o presente num evento do Heilsgeschichte" (PANNELL, 2004, p. 45). Nesse sentido, a história adquire um valor que não existia nas religiões das antigas culturas, pois o Heilsgeschichte é baseado na ideia de aliança que é firmada entre YHWH e seu povo "em Horebe" que se renova constantemente. Sobre isso, Snaith (1963 apud Ibid., p. 73) ainda explica: “A ação de Deus no mundo está sempre se renovando, é sempre contínua; sempre presente na história. Todo ponto [...] é o AGORA da ação divina.". 56

Conforme esse momento é lembrado como um dia em que houve a presença e o encontro divino, a revelação de YHWH para o seu povo se torna o ponto crucial do culto em Israel, que Weiser (1962 apud Ibid., p. 67) ${ }^{57}$ intitulou "Festa da Aliança de YHWH". Esse estudioso alemão observou a existência de dois principais elementos no festival cultual: actio

\footnotetext{
${ }^{56}$ SNAITH, Time in the Old Testament, in Promise and Fulfillment: Essays Presented to Professor S. H. Hooke

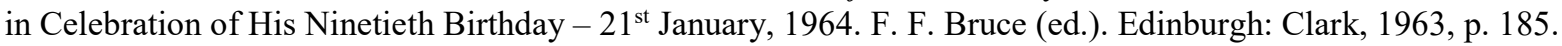

${ }^{57}$ WEISER, Artur. The Psalms: A Commentary. London: Westminster John Knox Press, 1962, p. 28-32.
} 
Dei (ação de Deus), que é constituído de:

- encontro;

- proclamação do nome de Deus;

- uma recapitulação do Heilsgeschichte;

- proclamação da vontade divina - o Decálogo;

e o reactio hominum (reação do homem), que pressupõe:

- a profissão de lealdade a YHWH;

- a renúncia de outros deuses.

Esse entendimento do festival cúltico da aliança coincide com a "memória" peculiar deuteronômica que é trazida para o presente através de uma palavra com denotação temporal particular: o hayyôm ("hoje”). Sobre isso, H. J. Kraus (1966) afirma: “o que é notável é a atualidade cultual do "hoje" que percorre todo o Deuteronômio e mostra a conexão que as tradições têm com a adoração" (KRAUS, 1966, p. 142). "Este dia" (também denotado por hayyôm) cultual não é um dia qualquer na história, pois a revelação de YHWH no Sinai não é algo que ficou num passado remoto quanto à geração a quem se dirige; mas é vivo e eficaz no presente, determinando e direcionando o modo de vida das pessoas do mesmo modo que fez com as pessoas que de fato testemunharam, ouviram e receberam a aliança. Por isso, essa palavra característica do Livro da Aliança requer da audiência de "hoje" uma escolha, uma resposta, através da obediência agora.

Por essa razão, faremos uma análise do termo הַּ (hayyôm), "hoje”, que ocorre em inúmeras passagens da $\mathrm{BH}$, especialmente tratado aqui em sua forma adverbial $^{58}: 28$ ocorrências no Tetrateuco, 60 no Deuteronômio (DE VRIES, 1975, p.140) ${ }^{59}, 102$ nos Profetas Anteriores e dez nos Profetas Posteriores, e dezessete nos demais livros (Ibid., p.153). ${ }^{60}$ É muito

\footnotetext{
${ }^{58}$ Nessa lista, também há ocorrências da forma hayyôm hazzeh, "este dia".

${ }^{59}$ Incluindo duas ocorrências na LXX, cf. DE VRIES, 1975, p.140.

Os termos ou expressões correspondentes na LXX são:

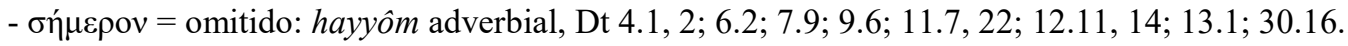

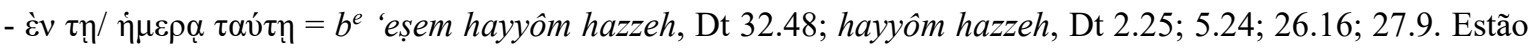
omitidos: hayyôm, Dt 15.15; 29.12, 17.

60 Mais especificamente, há catorze ocorrências em Gênesis, onze em Êxodo, três em Levítico, 60 em Deuteronômio, treze em Josué, sete em Juízes, 42 em 1Samuel, 24 em 2Samuel, onze em 1Reis, cinco em 2 Reis, uma em Isaías, 7seteem Jeremias, uma em Oseias, uma em Zacarias, três em Salmos, duas em Provérbios, uma
} 
interessante notar entre as ocorrências no livro de Deuteronômio que Deus é o agente direto em sete casos e agente indireto em 49 usos da expressão (WILCH, 1969, p. 67, 68 passim), o que significa que o termo possui uma relevância considerável e especial. No contexto do livro de Deuteronômio, הַירוֹ (hayyôm) é utilizado em referência a uma determinada condição de estado relevante do presente (p. ex. "mas vocês, que permaneceram fiéis ao SENHOR, o seu Deus, hoje estão todos vivos." - Dt 4.4) ${ }^{61}$, além disso, pode se referir a um ato significativo, assim como aparece muito na definição de um tratado, ou ainda num desafio a um comprometimento especial, como em "Reconheçam isso hoje, e ponham no coração que o SENHOR é Deus em cima nos céus e embaixo na terra. Não há nenhum outro.” (Dt 4.39). No entanto, a grande maioria das vezes (29) é empregada na entrega dos mandamentos ao povo sob a forma:

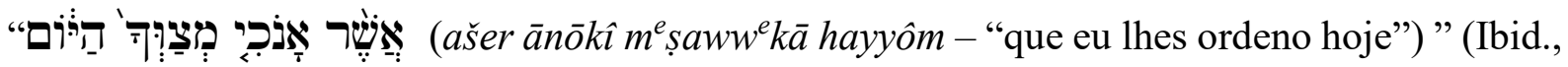
p. 67,68$)$.

Para uma visualização mais detalhada e didática das ocorrências do hayyôm em Deuteronômio, que são relacionadas à parte ou à linguagem da aliança a que se referem, conforme exposto no capítulo anterior, as ocorrências foram divididas em tabelas, como se segue:

Tabela 2

\begin{tabular}{|c|c|l|c|}
\hline & $\begin{array}{c}\text { Referência } \\
\text { Bíblica [Dt] }\end{array}$ & \multicolumn{1}{c}{$\begin{array}{c}\text { Hayyôm ligado a uma incumbência especial } \\
\text { ou experiência única }\end{array}$} & Relação com a Aliança \\
\hline $\mathbf{1}$ & 4.39 & $\begin{array}{l}\text { Reconheçam isso hoje, e ponham no coração que o SENHOR é Deus } \\
\text { em cima nos céus e embaixo na terra. Não há nenhum outro. }\end{array}$ & Prólogo histórico \\
\hline $\mathbf{2}$ & 5.24 & $\begin{array}{l}\text { O SENHOR, o nosso Deus, mostrou-nos sua glória e sua majestade, e } \\
\text { fós ouvimos a sua voz vinda de dentro do fogo. Hoje vimos que Deus }\end{array}$ & $\begin{array}{c}\text { Estipulações da aliança } \\
\text { [o Soberano YHWH, } \\
\text { Deus de Israel] }\end{array}$ \\
\hline $\mathbf{3}$ & 9.3 & $\begin{array}{l}\text { Esteja, hoje, certo de que o SENHOR, o seu Deus, ele mesmo, vai } \\
\text { adiante de você como fogo consumidor. }\end{array}$ & $\begin{array}{c}\text { Estipulações da aliança } \\
\text { [ação de YHWH] }\end{array}$ \\
\hline
\end{tabular}

em Jó, seis em Rute, uma em Ester, três em Neemias, uma em 1Crônicas e uma em 2Crônicas.

${ }^{61}$ Também em $5.3 ; 29.10 ; 15 ; 31.2$ ) 


\begin{tabular}{|c|c|l|c|}
\hline $\mathbf{4}$ & 11.2 & $\begin{array}{l}\text { Lembrem-se hoje de que não foram os seus filhos que experimentaram } \\
\text { e viram a disciplina do SENHOR, o seu Deus, a sua majestade, a sua } \\
\text { mão poderosa, o seu braço forte. }\end{array}$ & $\begin{array}{c}\text { Estipulações da aliança } \\
\text { [ação de YHWH] }\end{array}$ \\
\hline $\mathbf{5}$ & 27.9 & $\begin{array}{l}\text { Agora }(\text { hayyôm hazzeh) você se tornou o povo do SENHOR, o seu } \\
\text { Deus. }\end{array}$ & $\begin{array}{c}\text { "Fórmula" da aliança } \\
\text { [Rendtorff] }\end{array}$ \\
\hline
\end{tabular}

Tabela 3

\begin{tabular}{|c|c|c|c|}
\hline & $\begin{array}{l}\text { Referência } \\
\text { Bíblica [Dt] }\end{array}$ & $\begin{array}{c}\text { Hayyôm ligado a uma lembrança da ação de YHWH (sob a } \\
\text { fórmula: “como hoje se vê") }\end{array}$ & Relação com a Aliança \\
\hline 1 & 2.30 & $\begin{array}{l}\text { Mas Seom, rei de Hesbom, não quis deixar-nos passar; pois o SENHOR, } \\
\text { o Deus de vocês, tornou-lhe obstinado o espírito e endureceu-lhe o } \\
\text { coração, para entregá-lo nas mãos de vocês, como hoje se vê. }\end{array}$ & Prólogo histórico \\
\hline 2 & 4.20 & $\begin{array}{l}\text { A vocês, porém, o SENHOR tomou e tirou da fornalha de fun } \\
\text { dir ferro, do Egito, para serem o povo de sua herança, como hoje se } \\
\text { pode ver. }\end{array}$ & Prólogo histórico \\
\hline 3 & 4.(37),38 & $\begin{array}{l}\text { E porque amou os seus antepassados e escolheu a descendência deles, } \\
\text { ele foi em pessoa tirá-los do Egito com o seu grande poder, para } \\
\text { expulsar de diante de vocês nações maiores e mais fortes, a fim de } \\
\text { fazê-los entrar e possuir como herança a terra delas, como hoje se vê. }\end{array}$ & Prólogo histórico \\
\hline 4 & 6.24 & $\begin{array}{l}\text { O SENHOR nos ordenou que obedecêssemos a todos estes decretos e } \\
\text { que temêssemos o SENHOR, o nosso Deus, para que sempre fôssemos } \\
\text { bem-sucedidos e que fôssemos preservados em vida, como hoje se } \\
\text { pode ver. }\end{array}$ & $\begin{array}{l}\text { Estipulações da } \\
\text { aliança }\end{array}$ \\
\hline 5 & 8.18 & $\begin{array}{l}\text { Mas, lembrem-se do SENHOR, o seu Deus, pois é ele que lhes dá a } \\
\text { capacidade de produzir riqueza, confirmando a aliança que jurou aos } \\
\text { seus antepassados, conforme hoje se vê. }\end{array}$ & $\begin{array}{l}\text { Confirmação da aliança } \\
\text { [diretamente ligado ao } \\
\left.\text { termo } b^{e} r \hat{t} t\right]\end{array}$ \\
\hline 6 & 10.15 & $\begin{array}{l}\text { No entanto, o SENHOR se afeiçoou aos seus antepassados e os amou, } \\
\text { e a vocês, descendentes deles, escolheu entre todas as nações, como } \\
\text { hoje se vê. }\end{array}$ & $\begin{array}{l}\text { Estipulações da } \\
\text { aliança [hesed } \\
\text { YHWH] }\end{array}$ \\
\hline 7 & 29.28 & $\begin{array}{l}\text { Cheio de ira, indignação e grande furor, o SENHOR os desarraigou da } \\
\text { sua terra e os lançou numa outra terra, como hoje se vê. }\end{array}$ & Sanções da aliança \\
\hline
\end{tabular}


Tabela 4

\begin{tabular}{|c|c|c|c|}
\hline & $\begin{array}{l}\text { Referência } \\
\text { Bíblica [Dt] }\end{array}$ & $\begin{array}{l}\text { Hayyôm ligado à invocação de uma testemunha sobre um } \\
\text { juramento ou a uma advertência }\end{array}$ & Relação com a Aliança \\
\hline 1 & 4.26 & $\begin{array}{l}\text { invoco hoje o céu e a terra como testemunhas contra vocês de que } \\
\text { vocês serão rapidamente eliminados da terra, da qual estão tomando } \\
\text { posse ao atravessar o Jordão. }\end{array}$ & $\begin{array}{l}\text { Invocação de } \\
\text { testemunhas }\end{array}$ \\
\hline 2 & 8.19 & $\begin{array}{l}\text { Mas se vocês se esquecerem do SENHOR, o seu Deus, e seguirem } \\
\text { outros deuses, prestando-lhes culto e curvando-se diante deles, } \\
\text { asseguro-lhes hoje que vocês serão destruídos. }\end{array}$ & $\begin{array}{c}\text { Estipulações da aliança } \\
\text { [Sanções }]\end{array}$ \\
\hline 3 & 30.18 & eu hoje lhes declaro que, sem dúvida, vocês serão destruídos. & Sanções da aliança \\
\hline 4 & 30.19 & $\begin{array}{l}\text { Hoje invoco os céus e a terra como testemunhas contra vocês, de que } \\
\text { coloquei diante de vocês a vida e a morte, a bênção e a maldição. }\end{array}$ & $\begin{array}{l}\text { Invocação de } \\
\text { testemunhas }\end{array}$ \\
\hline
\end{tabular}

Tabela 5

\begin{tabular}{|c|c|c|c|}
\hline & $\begin{array}{l}\text { Referência } \\
\text { Bíblica [Dt] }\end{array}$ & $\begin{array}{c}\text { Hayyôm ligado a uma condição ou atividade } \\
\text { significativa do presente }\end{array}$ & Relação com a Aliança \\
\hline 1 & 4.4 & $\begin{array}{l}{[\ldots] \text { mas vocês, que permaneceram fiéis ao SENHOR, o seu Deus, hoje }} \\
\text { estão todos vivos. }\end{array}$ & Prólogo histórico \\
\hline 2 & 5.3 & $\begin{array}{l}\text { Não foi com os nossos antepassados que o SENHOR fez essa aliança, } \\
\text { mas conosco, com todos nós que hoje estamos vivos aqui. }\end{array}$ & $\begin{array}{l}\text { [diretamente ligado ao } \\
\left.\text { termo } b^{e} r \hat{\imath} t\right]\end{array}$ \\
\hline 3 & 5.24 & $\begin{array}{l}\text { Hoje vimos que Deus fala com o homem e que este ainda continua } \\
\text { vivo! }\end{array}$ & $\begin{array}{l}\text { Estipulações da aliança } \\
\text { [o Soberano YHWH] }\end{array}$ \\
\hline 4 & 9.1 & $\begin{array}{l}\text { Ouça, ó Israel: Hoje você está atravessando o Jordão para entrar na } \\
\text { terra e conquistar nações maiores e mais poderosas do que você, as } \\
\text { quais têm cidades grandes, com muros que vão até o céu. }\end{array}$ & $\begin{array}{l}\text { Diante da conquista } \\
\text { [cumprimento da } \\
\quad \text { aliança] }\end{array}$ \\
\hline 5 & 11.26 & $\begin{array}{l}\text { Prestem atenção! Hoje estou pondo diante de vocês a bênção e a } \\
\text { maldição. }\end{array}$ & $\begin{array}{l}\text { Declaração de bênção e } \\
\text { maldição }\end{array}$ \\
\hline
\end{tabular}




\begin{tabular}{|c|c|c|c|}
\hline 6 & 26.3 & $\begin{array}{l}\text { 'Declaro hoje ao SENHOR, o seu Deus, que vim para a terra que o } \\
\text { SENHOR jurou aos nossos antepassados que nos daria'. }\end{array}$ & $\begin{array}{l}\text { Conquista da terra } \\
\text { [cumprimento da } \\
\text { aliança] }\end{array}$ \\
\hline 7 & 26.17 & $\begin{array}{l}\text { Hoje vocês declararam que o SENHOR é o seu Deus e que vocês } \\
\text { andarão nos seus caminhos, que guardarão os seus decretos, os seus } \\
\text { mandamentos e as suas ordenanças, e que vocês the obedecerão. }\end{array}$ & $\begin{array}{l}\text { "Fórmula" da aliança } \\
\text { [Rendtorff] }\end{array}$ \\
\hline 8 & 26.18 & $\begin{array}{l}\text { E hoje o SENHOR declarou que vocês são o seu povo, o seu tesouro } \\
\text { pessoal, conforme ele prometeu, e que vocês terão que obedecer a } \\
\text { todos os seus mandamentos. }\end{array}$ & $\begin{array}{l}\text { "Fórmula" da aliança } \\
\text { [Rendtorff] }\end{array}$ \\
\hline 9 & 29.4 & $\begin{array}{l}\text { Mas até hoje o SENHOR não lhes deu mente que entenda, olhos que } \\
\text { vejam, e ouvidos que ouçam }\end{array}$ & \multirow{2}{*}{$\begin{array}{l}\text { Voto de confirmação da } \\
\text { aliança }\end{array}$} \\
\hline 10 & 29.10 & Hoje todos vocês estão na presença do SENHOR, o seu Deus $[\ldots]$ & \\
\hline 11 & 29.12 & $\begin{array}{l}\text { Vocês estão aqui presentes para entrar em aliança com o SENHOR, } \\
\text { o seu Deus, aliança que ele está fazendo com vocês hoje... }\end{array}$ & $\begin{array}{l}\text { [diretamente ligado ao } \\
\left.\text { termo } b^{e} r \hat{\imath} t\right]\end{array}$ \\
\hline 12 & 29.13 & para hoje confirmá-los como seu povo, para que ele seja o seu Deus, & $\begin{array}{l}\text { "Fórmula" da aliança } \\
\text { [Rendtorff] }\end{array}$ \\
\hline 13 & 29.15 & mas também com aqueles que não estão aqui hoje. & \multirow{2}{*}{$\begin{array}{l}\text { Voto de confirmação da } \\
\text { aliança }\end{array}$} \\
\hline 14 & 30.15 & $\begin{array}{l}\text { Vejam que hoje ponho diante de vocês vida e prosperidade, ou morte e } \\
\text { destruição. }\end{array}$ & \\
\hline
\end{tabular}

Tabela 6

\begin{tabular}{|c|c|c|c|}
\hline & $\begin{array}{c}\text { Referência } \\
\text { Bíblica [Dt] }\end{array}$ & \multicolumn{1}{c|}{ Hayyôm ligado à entrega de um decreto ou mandamento } & Relação com a Aliança \\
\hline $\mathbf{1}$ & 4.8 & $\begin{array}{l}\text { que grande nação tem decretos e preceitos tão justos como esta lei que } \\
\text { estou apresentando a vocês hoje? }\end{array}$ & Prólogo histórico \\
\hline $\mathbf{2}$ & 4.40 & $\begin{array}{l}\text { Obedeçam aos seus decretos e mandamentos que hoje eu lhes ordeno, } \\
\text { para que tudo vá bem com vocês e com seus descendentes }\end{array}$ & Estipulações da aliança \\
\hline
\end{tabular}




\begin{tabular}{|c|c|c|c|}
\hline 3 & 5.1 & $\begin{array}{l}\text { Ouça, ó Israel, os decretos e as ordenanças que hoje lhe estou } \\
\text { anunciando. }\end{array}$ & Estipulações da aliança \\
\hline 4 & 6.6 & Que todas estas palavras que hoje lhe ordeno estejam em seu coração. & Estipulações da aliança \\
\hline 5 & 7.11 & $\begin{array}{l}\text { Obedeçam, pois, à lei, isto é, aos decretos e às ordenanças que hoje } \\
\text { lhes ordeno. }\end{array}$ & Estipulações da aliança \\
\hline 6 & 8.1 & Tenham o cuidado de obedecer a toda a lei que eu hoje lhes ordeno & Estipulações da aliança \\
\hline 7 & 8.11 & $\begin{array}{l}\text { Tenham o cuidado de não se esquecer do SENHOR, o seu Deus, } \\
\text { deixando de obedecer aos seus mandamentos, às suas ordenanças e aos } \\
\text { seus decretos que hoje lhes ordeno. }\end{array}$ & Estipulações da aliança \\
\hline 8 & 10.13 & $\begin{array}{l}{[\ldots] \text { e que obedeça aos mandamentos e aos decretos do SENHOR, que }} \\
\text { hoje lhe dou para o seu próprio bem? }\end{array}$ & Estipulações da aliança \\
\hline 9 & 11.8 & Obedeçam, portanto, a toda a lei que hoje lhes estou dando, $[\ldots]$ & Estipulações da aliança \\
\hline 10 & 11.13 & $\begin{array}{l}\text { Portanto, se vocês obedecerem fielmente aos mandamentos que hoje } \\
\text { lhes dou }[\ldots]\end{array}$ & Estipulações da aliança \\
\hline 11 & 11.27 & $\begin{array}{l}\text { Vocês terão bênção, se obedecerem aos mandamentos do SENHOR, o } \\
\text { seu Deus, que hoje lhes estou dando; }\end{array}$ & Estipulações da aliança \\
\hline 12 & 11.28 & $\begin{array}{l}\text { mas terão maldição, se desobedecerem aos mandamentos do } \\
\text { SENHOR, o seu Deus, e se afastarem do caminho que hoje lhes } \\
\text { ordeno. }\end{array}$ & Estipulações da aliança \\
\hline 13 & 11.32 & $\begin{array}{l}\text { tenham o cuidado de obedecer a todos os decretos e ordenanças que } \\
\text { hoje estou dando a vocês. }\end{array}$ & Estipulações da aliança \\
\hline 14 & 15.5 & $\begin{array}{l}\text { contanto que obedeçam em tudo ao SENHOR, o seu Deus, e ponham } \\
\text { em prática toda esta lei que hoje lhes estou dando. }\end{array}$ & Estipulações da aliança \\
\hline 15 & 15.15 & É por isso que hoje lhe dou essa ordem. & Estipulações da aliança \\
\hline 16 & 19.9 & $\begin{array}{l}{[\ldots] \text { se vocês obedecerem fielmente a toda esta lei que hoje lhes }} \\
\text { ordeno: Amar o SENHOR, o seu Deus, e sempre andar nos seus } \\
\text { caminhos. }\end{array}$ & Estipulações da aliança \\
\hline 17 & 26.16 & $\begin{array}{l}\text { O SENHOR, o seu Deus, lhes ordena hoje que sigam esses decretos e } \\
\text { ordenanças }\end{array}$ & Estipulações da aliança \\
\hline
\end{tabular}




\begin{tabular}{|c|c|c|c|}
\hline 18 & 27.1 & Obedeçam a toda esta lei que hoje lhes dou. & Sanções da aliança \\
\hline 19 & 27.4 & {$[\ldots]$ como hoje lhes ordeno, } & Sanções da aliança \\
\hline 20 & 27.10 & $\begin{array}{l}\text { Obedeça ao SENHOR, o seu Deus, e siga os seus mandamentos e } \\
\text { decretos que hoje lhe dou }\end{array}$ & Sanções da aliança \\
\hline 20 & 28.1 & $\begin{array}{l}\text { Se vocês obedecerem fielmente ao SENHOR, o seu Deus, e seguirem } \\
\text { cuidadosamente todos os seus mandamentos que hoje lhes dou }\end{array}$ & Sanções da aliança \\
\hline 21 & 28.13 & $\begin{array}{l}\text { Se obedecerem aos mandamentos do SENHOR, o seu Deus, que hoje } \\
\text { lhes dou e os seguirem cuidadosamente }\end{array}$ & Sanções da aliança \\
\hline 22 & 28.14 & $\begin{array}{l}\text { Não se desviem, nem para a direita nem para a esquerda, de qualquer } \\
\text { dos mandamentos que hoje lhes dou }[\ldots]\end{array}$ & Sanções da aliança \\
\hline 23 & 28.15 & $\begin{array}{l}\text { não seguirem cuidadosamente todos os seus mandamentos e decretos } \\
\text { que hoje lhes dou [...] }\end{array}$ & Sanções da aliança \\
\hline 24 & 30.2 & $\begin{array}{l}{[\ldots] \text { lhe obedecerem de todo o coração e de toda a alma, de acordo com }} \\
\text { tudo o que hoje lhes ordeno }\end{array}$ & Sanções da aliança \\
\hline 25 & 30.8 & $\begin{array}{l}\text { Vocês obedecerão de novo ao SENHOR e seguirão todos os seus } \\
\text { mandamentos que lhes dou hoje. }\end{array}$ & $\begin{array}{l}\text { Votos de confirmação } \\
\text { da aliança }\end{array}$ \\
\hline 26 & 30.11 & $\begin{array}{l}\text { O que hoje lhes estou ordenando não é difícil fazer, nem está além do } \\
\text { seu alcance. }\end{array}$ & $\begin{array}{l}\text { Votos de confirmação } \\
\text { da aliança }\end{array}$ \\
\hline 27 & 30.16 & $\begin{array}{l}\text { Pois hoje lhes ordeno que amem o SENHOR, o seu Deus, andem nos } \\
\text { seus caminhos e guardem os seus mandamentos, decretos e } \\
\text { ordenanças; }\end{array}$ & $\begin{array}{l}\text { Votos de confirmação } \\
\text { da aliança }\end{array}$ \\
\hline 28 & 32.46 & $\begin{array}{l}\text { Guardem no coração todas as palavras que hoje lhes declarei } \\
\text { solenemente, para que ordenem aos seus filhos que obedeçam } \\
\text { fielmente a todas as palavras desta lei. }\end{array}$ & Continuação da aliança \\
\hline
\end{tabular}

A seguir, faremos uma análise um pouco mais detalhada de alguns versículos e perícopes de Deuteronômio mais relevantes neste estudo quanto à questão da "atualização". 


\subsubsection{DEUTERONÔMIO 4.39}

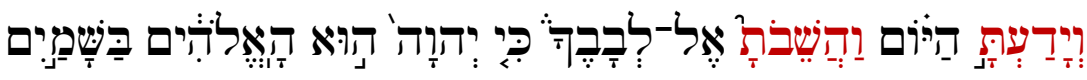

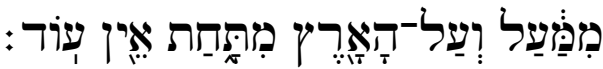

Reconheçam isso hoje, e ponham no coração que o SENHOR é Deus em cima nos céus e embaixo na terra. Não há nenhum outro. (NVI)

O capítulo quatro é o coração da teologia deuteronômica, segundo Jefrey Tigay (1996, p. 41, 42), pois expõe os preceitos fundamentais: o monoteísmo e a proibição da idolatria. Por sua vez, esse versículo em particular é o clímax da perícope Deuteronômio 4.32-40. Antes de mais nada, o v. 31 traz a figura de YHWH como aquele que não se esquece da aliança: "Pois o SENHOR, o seu Deus, é Deus misericordioso; ele não os abandonará, nem os destruirá, nem se esquecerá da aliança que com juramento fez com os seus antepassados.”

Logo em seguida, os v. 32-38 demonstram a verdade do monoteísmo, enfatizando que YHWH é o único Deus e como ele amou o povo que escolheu para ser o seu tesouro pessoal ${ }^{62}$, agindo poderosamente em favor dele (prólogo histórico); além disso, reforça que a misericórdia passada de YHWH tem um propósito bem definido no tempo presente; e termina com a expressão hayyôm hazzeh que permite identificar como ela se estende no dia de "hoje":

E porque amou os seus antepassados e escolheu a descendência deles, ele foi em pessoa tirá-los do Egito com o seu grande poder, para expulsar de diante de vocês nações maiores e mais fortes, a fim de fazê-los entrar e possuir como herança a terra delas, como hoje se vê.

Por fim, os v. 39-40 chamam Israel, ao reconhecimento de YHWH, hayyôm, para alcançar bênçãos futuras: "Obedeçam aos seus decretos e mandamentos que hoje eu lhes ordeno, para que tudo vá bem com vocês e com seus descendentes, e para que vivam muito tempo na terra que o SENHOR, o seu Deus, lhes dá para sempre.” É relevante ressaltar como as diversas versões da Bíblia apresentam traduções distintas para os verbos $\boldsymbol{y}_{\boldsymbol{\tau}} \boldsymbol{\tau}_{\boldsymbol{\tau}}$ (yâda),

\footnotetext{
62 Declarado mais explicitamente em Dt 26.18: "E hoje o SENHOR declarou que vocês são o seu povo, o seu tesouro pessoal, conforme ele prometeu, e que vocês terão que obedecer a todos os seus mandamentos."
} 


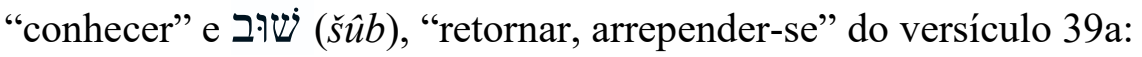

Por isso, hoje, saberás e refletirás no teu coração que [...] (ARA)

Fiquem sabendo agora e nunca esqueçam isto: $[. .$.$] (NTLH)$

Fiquem pois a saber [hoje] e fixem bem na memória que [...] (TPC)

Reconheçam isso hoje, e ponham no coração que [...] (NVI)

É pertinente observar o uso do termo ירָּ (yâda ): o povo deve "conhecer" que YHWH é único e não há outro como ele. Mas o que quer dizer isso? "Ficar sabendo", como traduz a TPC e a NTLH? Aqui, parece que não significa "tomar conhecimento", uma vez que eles já o conhecem de uma maneira bem próxima e já viram as maravilhas que ele realizou, conforme o texto confirma:

Pois, que grande nação tem um Deus tão próximo como o SENHOR, o nosso Deus, sempre que o invocamos? [...] Apenas tenham cuidado! Tenham muito cuidado para que vocês nunca se esqueçam das coisas que os seus olhos viram; conservem-nas por toda a sua vida na memória. Contem-nas a seus filhos e a seus netos. Lembrem-se do dia em que vocês estiveram diante do SENHOR, o seu Deus, em Horebe [...] (Dt 4. 7, 9-10)

Por isso, parece que "reconhecer" é a tradução mais adequada nesse caso. Eles devem reconhecer tudo o que já testemunharam YHWH fazer em favor deles, já que todo o capítulo 4 está baseado nas coisas que eles "ouviram" e "viram com os próprios olhos". É no sentido de "admitir como verdadeiro" e "mostrar gratidão" que YHWH deseja que seu povo o conheça ou

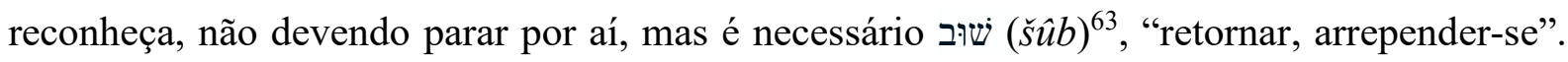
Então, surge mais uma questão: retornar para onde ou arrepender-se de que? Especialmente aqui, esse verbo é usado em um sentido incomum, que transmite a noção de "reforçar": "fazer de novo" ou "fazer algo maior ou cada vez mais" (NDITEAT, v.4, p. 57). Assim, a ideia de "fixar" no coração (TPC) ou "nunca esquecer" (NTLH) faz bastante sentido.

Finalmente, o papel especial de hayyôm no v. 39 pode ser visto neste esboço - o termo

\footnotetext{
${ }^{63}$ Também funcionam com os significados de voltar-se fisicamente e querem dizer também dar as costas para Deus (apostasia) ou voltar-se para Deus (arrependimento); às vezes, é usado com o sentido de fazer algo novamente (Gn 26.18; 2Rs 13.25) ou fazer algo maior ou cada vez mais (Ez 8.6, 17). cf. NDITEAT, v.4, p. 56-59.
} 
faz parte do fechamento da perícope, trazendo um apelo extremamente importante: reconheçam quem é YHWH em tudo e em todo tempo. E somente então chama o Israel à tomada de decisão; importante notar que YHWH chama o Israel de hoje, da nova geração que não o conhece pessoalmente, a tomar a mesma decisão dos seus antepassados de entrar no relacionamento de aliança.

Logo adiante, no v. 40 segue um apelo à obediência às leis e mandamentos como resposta aos feitos de YHWH, como também ocorre em Deuteronômio 26.16-18, em que esse apelo, que representa o centro da parênese deuteronômica, tão repetida nesse livro, é reforçado com a expressão "de todo o seu coração e de toda a sua alma".

\subsubsection{DEUTERONÔMIO 5.3 (apud DE VRIES, 1975, p. 173) ${ }^{64}$}

Esta é uma das passagens cruciais no entendimento da múltipla audiência apresentada de modo bastante típico no livro em questão:

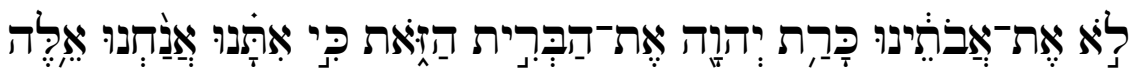

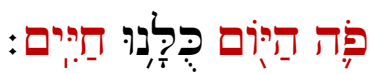

Não foi com os nossos antepassados que o SENHOR fez essa aliança, mas conosco, com todos nós que hoje estamos vivos aqui.

Os “antepassados" provavelmente se referem à geração que morreu no deserto, enquanto "todos nós que hoje estamos vivos aqui” são a audiência atual. Por isso, há uma necessidade crucial de repetir e "atualizar" a aliança, uma vez que "[...] foram vocês que viveram essa experiência e não os vossos filhos, que não conheceram diretamente as coisas" ${ }^{\prime 65}$ (Dt 11.2b).

\footnotetext{
${ }^{64}$ Provavelmente a passagem de Dt 5.3-5 representa uma expansão da introdução da versão original do decálogo deuteronômico, cf. Lohfink, Hauptgebot. Analecta Biblica 20. Rome, 1963, p. 145-148.

${ }^{65}$ Versão BÍBLIA: Tradução em Português Corrente, 1993.
} 
4.2.2.3 DEUTERONÔMIO 11.2 (apud DE VRIES, 1975, p. 175) ${ }^{66}$

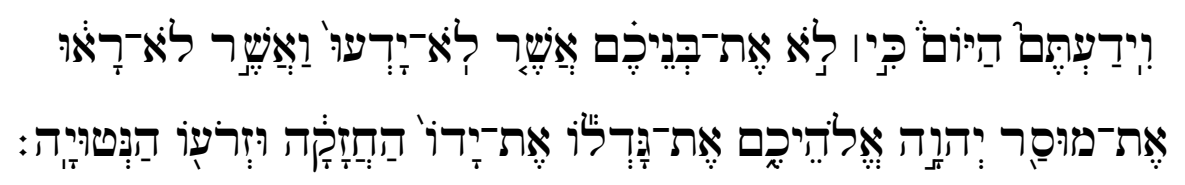

Lembrem-se hoje de que não foram os seus filhos que experimentaram e viram a disciplina do $\mathrm{SENHOR}^{67}$, o seu Deus, a sua majestade, a sua mão poderosa, o seu braço forte. (NVI)

O interessante é que Israel é chamado a reconhecer ${ }^{68}$ a poderosa ação de YHWH que eles mesmos testemunharam. Esse fato é percebido de modo mais claro na versão da Bíblia em português corrente: "Reconheçam hoje aquilo que aprenderam, ao verem a grandeza do Senhor, vosso Deus. Foram vocês que viveram essa experiência e não os vossos filhos, que não conheceram diretamente as coisas." No entanto, parece haver uma relação um tanto contraditória quanto à audiência quando comparamos ao v. 7, seguido do v. 8 e 9, em que diz:

Vocês mesmos viram com os seus próprios olhos todas essas coisas grandiosas que o SENHOR fez. Obedeçam, portanto, a toda a lei que hoje lhes estou dando, para que tenham forças para invadir e conquistar a terra para onde estão indo, e para que vivam muito tempo na terra que o SENHOR jurou dar aos seus antepassados e aos descendentes deles, terra onde manam leite e mel.

Quem são "vocês" do v. 7? Será que faz referência à geração atual, pois logo segue o apelo à obediência: "obedeçam [...] hoje". A audiência se confunde; no entanto, parece que como parte da tradição cúltica, o sentido é que toda nova geração está sendo chamada a participar da experiência da ação salvadora de YHWH, havendo apenas uma separação entre as gerações para delinear de quem é a responsabilidade de professar a fé na comunidade da aliança.

O mesmo ocorre em Deuteronômio 29.10-15, ${ }^{69}$ que contém cinco ocorrências de hayyôm e apresentam os diferentes grupos e gerações que estão envolvidos na relação de

\footnotetext{
${ }^{66}$ Na opinião de Lohfink, 1963, p. 219-231, esse material volta à liturgia antiga utilizada na cerimônia da aliança. 67 "Quem não conheceu e quem não viu a disciplina do Senhor". O uso dos verbos "saber" e "ver" indica que a experiência pessoal (saber ao ver) está em vista. O termo "disciplina" também pode ser "instrução". Cf. NETBIBLE, Dt 11, nota 3.

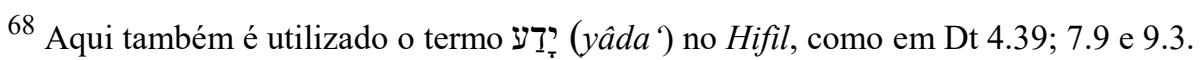

${ }^{69} \mathrm{Na} \mathrm{BH}$, as referências correspondem a Dt 29.9-14.
} 
aliança. A perícope se inicia com uma declaração geral: "Hoje todos vocês estão na presença do SENHOR, o seu Deus (v. 10a)" e segue dando detalhes de quem são "todos vocês" nos v. 10b, 11. Contudo, o que há de novo e relevante nessa perícope é a afirmação do v. 15, em que inclui os que não estão presentes pôh e hayyôm. Também é um esforço semelhante ao Deuteronômio 5.3 de estender a experiência da aliança às gerações posteriores: ${ }^{70}$

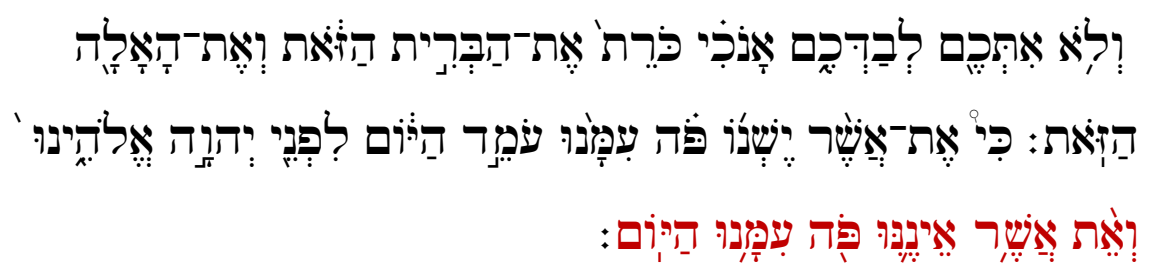

Não faço esta aliança, sob juramento, somente com vocês que estão aqui conosco na presença do SENHOR, o nosso Deus, mas também com aqueles que não estão aqui hoje" (Dt 29.14,15). (NVI)

E não é só para vocês que eu, o Senhor, faço esta aliança e este juramento. É, de facto, para quem se encontra aqui hoje connosco, presente diante do Senhor, nosso Deus, mas também para quem não está connosco. (TPC)

Portanto, o que realmente importa não é o acontecimento histórico em si, mas o evento da aliança entre YHWH e o seu povo que se estende às gerações atuais, e a sua relevância que é garantida para o dia de "hoje". Assim, a única expressão הָּ (hayyôm) consegue abranger o "hoje" referente a Moisés, assim como o de todas as gerações posteriores, enquanto o povo de Deus vive constantemente em tensão deuteronômica: entre a eleição (promessa) e o cumprimento (VON RAD, 2006, p. 219).

Dentro da esfera do culto, "todo Israel" - independente da época em que viveu ou vive: passado, presente ou futuro - celebra a "atualização" da aliança do Sinai. A passagem ou duração do tempo são irrelevantes. A ênfase está no conteúdo da aliança. O foco está no que aconteceu, não em quando aconteceu. O mesmo YHWH da experiência do deserto, que estava presente no meio do acampamento, continua guiando plenamente a vida do povo eleito, e afetando-a profundamente. É a partir dessa ideia de aliança mantida pelo דֶֶֶ (hesed) de YHWH - um amor fiel que cumpre a aliança - que essa nação ganha a sua identidade como povo de YHWH.

\footnotetext{
${ }^{70}$ Ocorre também em Dt 1.10, 39; 4.4.
} 


\section{CONCLUSÃO}

Como se pode observar, a experiência temporal do homem bíblico mostra-se diferenciada. Há um contraste entre Israel e os seus vizinhos. E isso não se dá apenas devido ao elemento concreto da temporalidade, mas principalmente por se tratar de um "tempo sagrado". Afinal, Israel se define a partir da aliança, e a aliança tem seus contornos a partir do Deus de Israel. Deus é o Deus da história, pois YHWH é descrito na Bíblia Hebraica como um Deus que age dentro da esfera do tempo; isso quer dizer que o tempo é o campo de ação e intervenção divina, conforme bem descrevem autores como Hans Walter Wolff (2007), Walter Israel Rehfeld (1988) e Simon De Vries (1974), já discutidos no primeiro capítulo.

Essa temporalidade sagrada é constatada semanticamente na Bíblia Hebraica. Nela encontramos um amplo vocabulário que denota essa ação redentora e libertadora de YHWH,

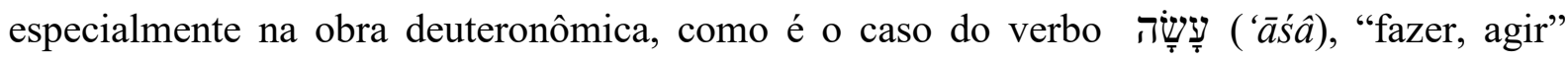
(DITAT, p. 1179-1181), usado frequentemente em referência ao marcante acontecimento do Êxodo $^{71}$, que define a identidade de Israel na Torá; essa ação divina é ainda mais especificamente denotada pelos verbos (pādâ) "resgatar, livrar" (DITAT, p. 1200-1202) 72. De fato, é com essa terminologia que Israel se torna o povo escolhido e é salvo por YHWH, a partir do momento em que foi tirado da escravidão do Egito:

E porque amou os seus antepassados e escolheu a descendência deles, ele foi em pessoa tirá-los do Egito com o seu grande poder [...] (Dt 4.37).

[...] Como você é feliz, Israel! Quem é como você, povo salvo pelo SENHOR? Ele é o seu abrigo, o seu ajudador e a sua espada gloriosa. (Dt 33.29)

Não se pode deixar de considerar o fato de que Deuteronômio ensina que YHWH também agiu em favor do seu povo através de orientação segura durante as peregrinações pelo

\footnotetext{
${ }^{71}$ Como em Dt 4.34; 7.18; 29.2; 34.12.

72 Essa raiz em outras línguas semíticas, como árabe, acadiano e ugarítico, também são usadas no sentido de resgatar mediante pagamento de resgate. Esse verbo é muito utilizado para descrever o ato de libertar alguém do poder de outro pelo pagamento de um resgate cf. THOMPSON, 1982, p.70.
} 
deserto, o que tinha como objetivo o cumprimento de sua aliança com os seus antepassados (Gn 15). Foi dessa forma que YHWH agiu na história de Israel, dirigindo o seu curso para atingir seus próprios fins, conforme a narrativa bíblica. E aqui é muito importante ressaltar que foi o conhecimento do Deus da aliança e de si mesmo como povo eleito, além da ação libertadora de YHWH que gerou a capacidade de compreensão do processo histórico e das diretrizes para a interpretação da história da salvação ${ }^{73}$ de Israel, segundo Eichrodt (2005, p. 36).

No entanto, em alguns momentos dessa história de libertação, Israel se encontra diante de situações que ameaçam a sua identidade. Neste ponto, é importante ressaltar o valor particular do livro de Deuteronômio para essa questão. Sabe-se que há uma grande discussão em torno da datação do livro; no entanto, há uma ampla aceitação de que parte significativa do

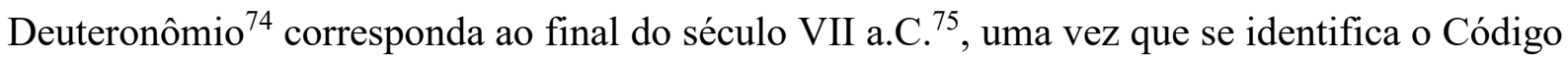
de Lei deuteronômico com o Livro da Lei descoberto no templo durante sua reforma, relatado em 2 Reis 22.8-20 (Weinfeld, 1992, p. 1-9). Por mais que se possam detectar possíveis camadas literárias mais antigas ou mais recentes na redação de Deuteronômio, há um certo consenso de que o seu enfoque sobre a relação entre YHWH, Israel e os demais povos está em sintonia com o contexto do século VII a.C., no Reino de Judá.

A retrospectiva histórica do Israel da época do Primeiro Templo mostra que a partir da fundação do Reino do Norte, separado do Reino do Sul por volta do final do séc. X a.C. (época de Jeroboão I e de Roboão), até a tão significativa reforma religiosa judaíta do rei Josias ${ }^{76}$ (2Rs 22-23), houve uma diversificação de divindades e de culto, além de um crescimento das formas sincréticas no culto a YHWH. O desafio monoteísta israelita de sobreviver no ambiente cananeu de religiosidade ligada à fertilidade da terra é o pano de fundo por trás desse sincretismo. Além

\footnotetext{
${ }^{73}$ Heilsgeschichte.

74 Entende-se que esse material corresponda a Dt 4-11, 27-29 cf. Ellman, 2013, p. 10.

75 Outra visão remete o Código da Lei ao século VIII a.C. no contexto da reforma de Ezequias, ao mesmo tempo em que atribui grande parte do quadro ao período josiânico, cf. Rosenbaum, Jonathan. Hezekiah's Reform and the Deuteronomistic Tradition. Harvard Theological Review 72, 1979, p. 23-43. Também é possível encontrar opinião de uma data quase exílica para o material, com possibilidade de uma "dupla redação", cf. a posição da chamada "Escola Americana" de Frank Moore Cross e seus alunos; Cross, Canaanite Myth and Hebrew Epic, 274-85, apud Ellman, 2013, p. 10 (nota de rodapé).

76 A reforma religiosa de Josias que centralizou o culto, restringindo o sacrifício ao "lugar de YHWH" (Dt 12.5; $14.23 ; 15.20 ; 16.2$, etc.) e a proibição de todos os altares, santuários e imagens estrangeiros (Dt 12.2-5) estão de acordo com o ethos do Código da Lei. Muitos dos temas expressos nesse material, incluindo a importância atribuída à verbalização da memória, também podem ser explicados em conexão com as exigências políticas do reinado de Josias ou como uma resposta teológica à recente proeminência de Judá na após a queda do Reino do Norte, em 722 a.C.
} 
disso, a história deuteronomista vai relatar os sucessivos governos de reis que "fizeram o que YHWH reprova" (a partir do paradigma de Jeroboão I), sangrentos golpes de Estado (2Rs 15), sem falar do repovoamento da região da antiga Samaria por contingentes assírios. É mais do que compreensível como tudo isso significou uma ameaça terrível à identidade de Israel como povo de YHWH. A assimilação sempre foi uma possibilidade.

Esse drama de conservação da identidade do povo da aliança pode ser também percebido quando o texto bíblico se detém no momento iminente à conquista da terra prometida, em Moabe, conforme relatado em Deuteronômio 1-11, 12-26 e 27-34. Ali vemos que após longos anos de peregrinação pelo deserto, Israel quase deixa de ser Israel. A ocasião de chegada ao ponto final da promessa divina representou um momento crítico quanto à identidade de Israel, pois estas não eram as gerações que haviam conhecido YHWH por experiência própria: eles não haviam visto os milagres nem o cuidado divino durante a jornada, nem tampouco estavam presentes no momento em que YHWH firmou a aliança com seu povo. Além do mais, na terra de que tomariam posse, eles haveriam de sofrer grande influência dos povos politeístas que adoram outros deuses e cairiam em idolatria crescente. Então, por que eles continuariam cultuando YHWH?

É exatamente nesses momentos críticos que se faz necessário "lembrar" o povo veementemente de quem é o seu libertador, desde os tempos dos seus antepassados. Nesse contexto, é crucial “lembrar” Israel que (Dt 6.4):

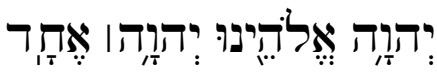

(YHWH 'élōhênû YHWH 'ehād - YHWH, nosso Deus, YHWH, Um)

reforçando que há somente um Deus que elegeu Israel seu povo, o que é expresso através da ideia de $s^{e}$ gullah: ${ }^{77}$ "tesouro pessoal”. Esse status tão especial é também expresso pela frase ' $m$ $q d w \check{s}$, "povo santo", que serve de motivação para responder com lealdade e obediência ao hesed ${ }^{78}$ YHWH: "E hoje o SENHOR declarou que vocês são o seu povo, o seu tesouro pessoal, conforme ele prometeu, e que vocês terão que obedecer a todos os seus mandamentos" (Dt 26.18). Esses são justamente os temas abordados em Deuteronômio, conforme tratado no segundo capítulo.

\footnotetext{
77 “Possessão especial”, cf. WEINFELD, 1991, p. 60.

${ }^{78}$ Amor leal que cumpre a aliança, cf. DITAT, p. 500
} 
A proclamação de um Deus único e a centralização do culto realizada na reforma de Josias revolucionou a religião de Israel, pois significou uma inovação em sua história (WEINFELD, 1991, p. 37). A excessiva diversidade religiosa ${ }^{79}$ e o sincretismo poderiam dar fim a Israel. Mas, a proclamação deuteronômica serviu especialmente para superar a ameaça de perder sua identidade e renová-la, conforme explica Reimer:

Os projetos e as práticas expansionistas de Josias e sua reforma políticoreligiosa constituem o evento histórico mais importante desse período. Foi um momento em que, entre adesão e coerção, se constituíram traços marcantes da identidade do Israel do período. (REIMER, 2012, p. 190)

A eliminação de todos os santuários além do lugar escolhido por YHWH (ênfase tão deuteronômica), provavelmente deixou um vácuo na vida religiosa das pessoas que habitavam em áreas mais distantes, já que era tão difícil e dispendioso viajar tanto para Jerusalém. E, nessa ausência de oportunidades de participar dos rituais sacrificiais, a exigência de que a doutrina fosse continuamente aprendida e revivida encontrou certas dificuldades para ser cumprida. Por isso, o kerygma deuteronômico transmitido pelos antepassados como uma memória coletiva compartilhada na liturgia e como algo que Israel tem o dever de aprender e inculcar dentro do contexto da aliança, ofereceu uma maneira de sustentar a comunidade da fé. Nesse sentido, a centralidade da aliança deixa de ter um papel apenas no âmbito religioso, mas passa a reger a vida cotidiana de todos os que se comprometeram a ela. Em outras palavras, a aliança também não se restringe a um indivíduo, mas ao povo, como um todo, que aceitou a fé no Deus único e abandonou para sempre os outros deuses, ao firmar a aliança com YHWH; pois, quando os israelitas, todos juntos, ouviram: "Eu sou YHWH, teu Deus", todos se tornaram responsáveis pela obediência. Por isso, todo Israel é convocado a lembrar dos atos de intervenção de YHWH na história, seguida de um apelo ${ }^{80}$ : "E agora ( $w^{e}$ 'attâ), ó Israel, ouça os decretos e as leis [...]." (Dt 4.1).

Através desse apelo, o chamado de Israel como povo de YHWH também é renovado: o hesed de Deus deve ser retribuído com amor integral - não se trata de um sentido psicológico, mas deve fluir em obediência em termos práticos à sua justa vontade em todas as áreas da vida

\footnotetext{
${ }^{79}$ O Museu de Israel traz entre muitos achados arqueológicos um "Santo dos Santos", encontrado em Tel-Arad. As indicações são de que se trata de um santuário paralelo ao de Jerusalém, do séc. VIII a.C. (Ezequias?), em Judá. A importância de um santuário central único é mais do que compreensível.

${ }^{80}$ Também em Dt 4.34; 5.6; 6.21-23; 7.8,18,19; 9.26; 26.8; 29.2,3; 34.11,12, e outros.
} 
pessoal e nacional.

Diante dessa compreensão é que se percebe a razão por que a aliança deve ser renovada continuamente. Afinal, é a aliança que dá sentido e finalidade à vida. Por essa razão, o culto de Israel era centrado em reencenações dramáticas do passado, de modo a incutir significado e direção para o presente. Em outras palavras, a libertação temporal "em Horebe" deve ser lembrada, mas, não pode permanecer como uma simples memória; precisa se tornar um dia "perpétuo" de encontro e aliança divina, para que as gerações seguintes sejam tomadas por um sentimento de continuidade e pertencimento (identidade). Assim, vivendo o dia crucial "em Horebe" de novo e de novo, "atualizadas" hayyôm, faz com que Israel passe a entender a própria existência de modo singular como povo de YHWH. Sobre isso, Von Rad (2006) reitera diversas vezes em quase toda sua obra que cada geração se reencontrava diante da tarefa sempre idêntica e nova de se compreender como Israel. Num certo sentido, cada geração devia tornarse Israel através da “apropriação”.

Assim, como YHWH age dentro da esfera temporal, é através do tempo deuteronômico expresso no termo hayyôm que torna possível capturar a mensagem no dia de "hoje" a cada nova geração do povo de YHWH, não importando o momento histórico; pois, esse kerygma que envolve o hayyôm serve para "unir" gerações no conhecimento desse Deus e dos seus atos de salvação, exortando-as à fidelidade a YHWH. O hayyôm torna-se, portanto, fundamental para a apropriação de identidade que se define a partir da aliança. Pois esse hayyôm é a referência pela qual se dá a apropriação e a retomada da identidade do povo perante YHWH. É uma "presentificação" que reconstrói o passado e prepara a direção de um futuro promissor. E é importante destacar que essa identidade vai além de costumes, crenças e memórias comuns; ela é "o caráter do povo que vai se definindo ao longo de sua existência e fica impresso em sua consciência histórica, tendo como base suas próprias tradições em sua singularidade, na maneira como vão sendo atualizadas por cada geração" (KAUFMANN, T., 1991, p. 9). Como também resume Andrew D. H. Mayes (In: CLEMENTS, 1989, p. 62):

A religião israelita, entendida como expressão da identidade social e como dependente relacionada com a sociedade, é pressuposta na definição de Brueggemann (1979) das duas trajetórias que se devem traçar através da história da religião de Israel, refletindo cada uma a teologia/ideologia de diversos grupos sociais: a trajetória da aliança de Moisés, enraizada na comunidade tribal israelita e a trajetória da aliança davídica [...]. 
Assim, depois de nossa trajetória de pesquisa sobre o tema, podemos concluir que a questão da temporalidade sagrada, específica em Deuteronômio, ligada à aliança de YHWH com seu povo, resulta na perpetuação desse tempo que é experienciado de geração a geração através do hayyôm e, desse modo, é possível alcançar a compreensão de que o papel do hayyôm é tornar a aliança entre YHWH e seu povo sempre atual e real para quem a recebe, e, portanto, incutindo uma percepção de "atemporalidade" 81 a ela, no sentido em que não é afetada ou controlada pelo tempo. Além disso, o termo hayyôm imprime a identidade de Israel como povo de YHWH de modo contínuo e sem fim, através de sua "atualização".

81 "Atemporal" é um adjetivo usado para (1) qualificar algo ou alguém que não é afetado pelo passar do tempo, ou seja, que faz parte de qualquer época ou tempo, cf. www.significados.com.br; (2) que não pode ser controlado pelo tempo; que não se adequa a qualquer tempo; intemporal, cf. https://www.dicio.com.br/atemporal/. 


\section{REFERÊNCIAS}

ACHTEMEIER, Paul J. (Ed.). Harper's Bible Dictionary. San Francisco: Harpercollins, 1985.

AGOSTINHO, Santo. Confissões Livros VII, X, XI. Covilhã: Lusosofia, 2008. Tradução: Arnaldo do Espírito Santo; João Beato; Maria Cristina Castro-Maia de Sousa Pimentel. Disponível em:

http://www.lusosofia.net/textos/agostinho de hipona confessiones livros vii x xi.pdf. Acesso em: 03 jan 2017.

ALTER, R.; Kermode, F. Guia Literário da Bíblia. São Paulo: UNESP, 1992.

BALLARINI, Teodorico. Introdução à Bíblia: Pentateuco. Petrópolis: Vozes, 1975.

BARR, James. Biblical Words for Time. London: SCM, 1962.

. The Semantics of Biblical Language. Oxford: Oxford University Press, 1961.

BARTON, John (Ed). Bible and interpretation: the collected essays of James Barr.

Oxford: Oxford University Press, 2011.

BARUCQ, A., et al. Escritos do Oriente Antigo e Fontes Bíblicas. São Paulo: Paulinas, 1992.

BECKWITH, Roger T. The Unity and Diversity of God's Covenants. The Tyndale Bulletin 38, 1987. p. 93-118.

Disponível em:

http://www.tyndalehouse.com/TynBul/Library/TynBull_1987_38_04_Beckwith_GodsCovena nt.pdf. Acesso em 15 jan 2016.

BEREZIN, Rifka. Dicionário Hebraico-Português. São Paulo: Edusp, 1995.

BÍ́BLIA Almeida Século 21. São Paulo: Vida Nova, 2008. 
BÍBLIA de Estudo Arqueológica NVI. São Paulo: Vida, 2013.

BÍBLIA de Jerusalém. 1ª ed. São Paulo: Paulus, 2002.

BÍBLIA Hebraica Stuttgartensia. K. Elliger; W. Rudolph. Stuttgart: Deutsche Bibelgesellschaft, 1983.

BÍBLIA. New English Translation Bible. Disponível em: https://net.bible.org.

BÍBLIA Nova Versão Internacional. São Paulo: Sociedade Bíblica Internacional, 2001.

BÍBLIA: Tradução Ecumênica. São Paulo: Loyola, 1994.

BÍBLIA: Tradução Norte-coreana. Sociedade Bíblica da Coreia do Norte, 1990.

BÍBLIA: Tradução em Português Corrente. Lisboa: Sociedade Bíblica de Portugal, 1993.

BÍBLIA. Tradução Septuaginta. Vetus Testamentum Graece. Alfred Rahlfs (Ed.).

Deutsche Bibelgesellschaft, 2006.

BOMAN, Thorleif. Hebrew Thought Compared with Greek. New York: W.W. Norton \& Company, 1970.

BOTTERWECK, G. Johannes; RINGGREN, Helmer. Theological Dictionary of the Old Testament. Michigan: William B. Eerdmans, 1995. Vol. 6.

BRIEND, Jacques. Uma Leitura do Pentateuco. São Paulo: Paulus, 1985.

BRIEND, J. et al. Israel e Judá: Textos do Antigo Oriente Médio. São Paulo: Paulus, 1985.

BRIN, Gershon. The Concept of Time in the Bible and the Dead Sea Scrollls. Leiden: Brill, 2001.

BROWN, Francis; DRIVER, S. R.; BRIGGS, Charles A. A Hebrew and English Lexicon of the Old Testament. Oxford: Clarendon, 1974. 
BRUEGGEMANN, Walter. Deuteronomy. Nashville: Abingdon, 2001. (Abingdon Old Testament Commentaries.)

A Social Reading of the Old Testament: Prophetic Approaches to Israel's Communal Life. Patrick D. Miller (Ed.). Philadelphia: Fortress, 1994.

. Old Testament Theology: Essays on Structure, Theme, and

Text. Patrick D. Miller (Ed.). Philadelphia: Fortress, 1992.

BRUEGGEMANN, Walter.; WOLFF, Hans W. O Dinamismo das Tradições do Antigo Testamento. São Paulo: Paulinas, 1984.

BUNDVAD, Mette. Defending the Concept of Time in the Hebrew Bible. Scandinavian Journal of the Old Testament. Copenhagen, 2014, v.28, n.2, p.280-297.

CARRIÈRE, J.-M. O livro do Deuteronômio. São Paulo: Loyola, 2005.

CHILDS, Brevard S. Memory and Tradition in Israel. London: SCM, 1962. Introduction to the Old Testament as Scripture. Philadelphia:

Fortress, 1979.

CHOURAQUI, André. A Bíblia: Palavras (Deuteronômio). Rio de Janeiro: Imago, 1997.

CHRISTENSEN, Duane L. Deuteronomy. Nashville: Thomas Nelson, 2001. (Word Biblical Commentary). Vol. 6.

CHWARTS, Suzana. Dos Estudos Comparativos. In: Via Maris: Texto e Contexto da Bíblia Hebraica. São Paulo: Humanitas, 2014. p. 117-121.

. O Impacto da Literatura do Oriente Médio Antigo na Elucidação da Bíblia Hebraica. In: Via Maris: Texto e Contexto da Bíblia Hebraica. São Paulo: Humanitas, 2014. p. 123-140. 
CLEMENTS, R. E. Deuteronomy. Sheffield: Sheffield, 1993.

. Deuteronomy and the Jerusalem Cult Tradition. Vetus Testamentum,

v.15, n. 3, p. 300-312, 1965. Brill Academic Publishers.

Disponível em: http://dx.doi.org/10.1163/156853365x00170. Acesso em 12 jan 2016.

O Mundo do Antigo Israel. São Paulo: Paulus, 1989.

COLLINGWOOD, R. G. The Idea of History. Oxford: Clarendon, 1946.

CRAIGIE, Peter C. The Book of Deuteronomy. Grand Rapids: Eerdmans, 1976. (The New International Commentary on the Old Testament).

CULLMANN, Oscar. Cristo e o Tempo. São Paulo: Custom, 2003.

DE PURY, Albert. O Pentateuco em questão. Petrópolis: Vozes, 2002.

DE VRIES, Simon J. The Development of the Deuteronomic Promulgation Formula. Biblica, v. 55, n. 3, 1974. p. 301-316.

Disponível em: http://www.jstor.org/stable/42609908. Acesso em 15 jan 2016.

. Yesterday, Today and Tomorrow: Time and History in the Old

Testament. Grand Rapids: Eerdmans, 1975.

DONNER, Herbert. História de Israel e dos Povos Vizinhos. Petrópolis: Sinodal/Vozes, 1997. 2 v.

DRIVER, S. R. A Critical and Exegetical Commentary on Deuteronomy. Edinburgh: T\&T Clark, 1902. (International Critical Commentary Series).

DUMBRELL, W. J. Covenant and Creation: A Theology of Old Testament Covenants. Nashville: Thomas Nelson, 1984.

EICHRODT, Walter. Teologia do Antigo Testamento. São Paulo: Hagnos, 2005.

EISSFELDT, Ott. The Old Testament: An Introduction. New York: Harpercollins, 1965. 
ELIADE, Mircea. História das Crenças e das Ideias Religiosas. Rio de Janeiro: Zahar, 1978.

Book, 1959.

The Sacred and the Profane: the Nature of Religion. New York: Harvest

ELLMAN, Barat. Memory and Covenant: The Role of Israel's and God's memory in Sustaining the Deuteronomic and Priestly Covenants. Augsburg: Fortress, 2013.

FLEW, Antony. Divine Omnipotence and Human Freedom. In: FLEW, Antony;

MACINTYRE, Alasdair C. (Ed.). New Essays in Philosophical Theology. London: SCM, 1955. p. 144-169.

FOHRER, Georg. História da Religião de Israel. São Paulo: Paulinas, 1983.

FREEDMAN, David N. (Ed.). Anchor Bible Dictionary. New York: Doubleday, 1992. 6 v.

GERSTENBERGER, Erhard S. Deus no Antigo Testamento. São Paulo: Aste, 1981.

GIRDLESTONE, R. B. Synonyms of the Old Testament. Grand Rapids: Baker, 1983.

GOLDINGAY, John. Approaches to Old Testament Interpretation. Downers Grove: Intervarsity Press, 1981.

GOTTWALD, Norman K. Introdução Socioliterária à Bíblia Hebraica. São Paulo:

Paulinas, 1988.

Vida Nova, 2004.

GRUDEM, Wayne. Teologia Sistemática. São Paulo: Vida Nova, 1999.

HARRINGTON, Wilfrid J. Chave para a Bíblia. São Paulo: Paulinas, 1985.

HARRIS, R. L.; Archer, G. L.; Waltke, B. K. Dicionário Internacional de Teologia do Antigo Testamento. São Paulo: Vida Nova, 1998.

HOUSE, Paul R. Teologia do Antigo Testamento. São Paulo: Vida, 1998. 
JENNI, Ernest.; WESTERMANN, Claus. Theological Lexicon of the Old Testament. Massachusetts: Hendrickson, 1994.

JONES, Landon. Gerhard von Rad e o Kerygma do Pentateuco. Revista Theos, $6^{\text {a }}$ Ed, v.5, n.2, dez, 2009. Disponível em: http://www.revistatheos.com.br/Artigos/Artigo_06_2_04.pdf. Acesso em 16 jan 2016.

JOSEPH, Brian D.; JANDA, Richard D. The Handbook of Historical Linguistics. Oxford: Blackwell, 2005.

KAUFMANN, Tânia N. Etnia, Credo ou Nação: Explicações de Uma Identidade. 1991. 124f. Dissertação (Mestrado) Curso de Antropologia, Universidade Federal de Pernambuco, Recife, 1991.

KAUFMANN, Yehezkel. A Religião de Israel. São Paulo: Perspectiva/EDUSP, 1989.

KAUTZCH, E.; COWLEY. A. E. (Ed). Gesenius' Hebrew Grammar. New York: Oxford University Press, 1910.

KLINE, Meredith G. Treaty of the Great King. Grand Rapids: Eerdmans, 1963.

KOEHLER, Ludwig; BAUMGARTNER, Walter. Hebrew and Aramaic Lexicon of the Old Testament. Leiden: Brill, 1994. 5 v.

KOROŠEC, V. Romanitas: revista de cultura Romana. Rio de Janeiro: Ano III, v. 3 e 4, 1961. p. 261-277.

KRAUS H. J. Worship in Israel. Oxford: Blackwell, 1966.

LAMADRID, Antonio G. Los descubrimientos del Mar Muerto. Biblioteca de Autores Cristianos, Barcelona: 1971. p. 243-244.

LAMBERT H. H. Getting inside the Bible. Minnesota: Bethany Press, 1976.

LEMKE, Werner E. Revelation through History in Recent Biblical Theology. Interpretation, v.36, n.1, 1982, p. 34-46.

Disponível em: http://journals.sagepub.com/doi/pdf/10.1177/002096438203600104. Acesso em 16 jan 2016. 
LOHFINK, Norbert. Grandes Manchetes de Ontem e de Hoje: o Antigo Testamento e os grandes temas de nossos dias. São Paulo: Paulinas, 1984.

LOPES, Félix G. O Deuteronômio: Uma Lei Pregada. São Paulo: Paulinas, 1992.

MARSH, John. The Fulness of Time. London: Nisbet \& Co., 1952.

MAYES, A. D. H. Deuteronomy. Grand Rapids: Eerdmans, 1981. (New Century Bible Commentary Series).

MCCONVILlE, J. G.; MILlAR, J. G. Time and Place in Deuteronomy. Journal for the Study of the Old Testament, Supplement series 179. Sheffield: Sheffield, 1994.

MENDENHALL, George E. Covenant Forms in Israelite tradition. Biblical Archaeologist, v.17, n.3, set, 1954. p. 50-76.

The Suzerainty Treaty Structure: Thirty Years Later. In:

FIRMAGE, Edwin B.; WEISS, Bernard G.; WELCH, John W. (Ed.). Religion and law:

Biblical-Judaic and Islamic perspectives. Winona Lake: Eisenbrauns, 1990. p. 85-100.

MILLS, Watson E. Mercer Dictionary of the Bible. Georgia: Mercer University Press, 1990.

MYERS, A. C. The Eerdmans Bible Dictionary. Grand Rapids: Eerdmans, 1987.

NICHOLSON, E. W. God and his People: Covenant and Theology in the Old Testament. Oxford: Clarendon, 1986.

OLIVEIRA, Roberto C. Identidade, Etnia e Estrutura Social. São Paulo: Livraria Pioneira, 1976.

PANNELL, J. R. Those Alive Here Today: The "Day of Horebe" and Deuteronomy's Hermeneutical Locus of Revelation. Longwood: Xulon Press, 2004.

PRITCHARD, J.B. Ancient Near Eastern Texts Related to the Old Testament. $3^{\text {rd }}$ ed. Princeton: Princeton University, 1958. 
REHFELD, Walter I. Tempo e Religião: A Experiência do Homem Bíblico. São Paulo: Perspectiva, 1988.

RENDTORFF, Rolf. The Covenant Formula: An Exegetical and Theological Investigation. Old Testament Studies. Edinburgh: T\&T Clark, 1998.

ROBINSON, H. Wheeler. Inspiration and revelation in the Old Testament. Oxford: Clarendon, 1946.

ROWLEY, H. H. A Fé em Israel, Aspectos do Pensamento do Antigo Testamento. São Paulo: Teológica, 2003.

SÁNCHEZ, Edesio. Deuteronomio, Introducción y Comentario. Buenos Aires: Kairós, 2002.

SANDMELL, Samuel. The Hebrew Scriptures: Introduction to their Literature and Religious Ideas. New York: Alfred Knopf, 1963.

SAYÃO, Luiz A. O Problema do Mal no Antigo Testamento. São Paulo: Hagnos, 2012. . Rota 66: Comentário Bíblico em Áudio. São Paulo: RTM, 2010.

SCHÖKEL, L. A. Dicionário Bíblico Hebraico-Português. São Paulo: Paulus, 1997.

SCOTT, R. B. Y. Os Profetas de Israel: nossos contemporâneos. São Paulo: ASTE, 1968.

SMITH, Ralph L. Teologia do Antigo Testamento. São Paulo: Vida Nova, 2001.

SPEISER, E. A. Genesis. New Heaven: Yale University Press, 1963. (The Anchor Bible Commentary). Vol. 1.

STERN, Sacha. Time and Process in Ancient Judaism. Oxford: The Littman Library of Jewish Civilization, 2007.

THE HOLY BIBLE. English Standard Version. Illinois: Good News Publishers, 1973. 
TIGAY, Jeffrey. Deuteronomy. Philadelphia: Jewish Publication Society, 1996. (JPS Torah Commentary).

TRESMONTANT, Claude. A Study of Hebrew Thought. New York: Desclee Company, 1960.

THOMPSON, J. A. Deuteronômio, Introdução e Comentário. São Paulo: Vida Nova, 1982. (Série Cultura Bíblica).

Tyndale, 1964.

The Ancient Near Eastern Treaties and the Old Testament. London:

VAUX, Roland de. Instituições de Israel no Antigo Testamento. São Paulo: Vida Nova, 2004.

VON RAD, G. Deuteronomy: A Commentary. Westminster: John Knox, 1996. (The Old Testament Library)

Teologia do Antigo Testamento. São Paulo: Targumim, 2006.

WALTKE, Bruce K.; O’CONNOR, M. Introdução à Sintaxe do Hebraico Bíblico. São Paulo: Cultura Cristã, 2006.

WALTON, John H. Covenant. Grand Rapids: Zondervan, 1994.

WEINFELD, Moshe. Deuteronomy. New Heaven: Yale University Press, 1991. (The Anchor Bible Commentary). Vol. 5.

Deuteronomy and the Deutoronomic School. Indiana: Eisenbrauns,

1992.

WESTERMANN, Claus. Teologia do Antigo Testamento. São Paulo: Paulinas, 1987.

WILCH, John R. Time and Event. Leiden: E. J. Brill, 1969.

WILLESON, Folker. The Yālīd in the Hebrew Society. Studia Theologica, v.12, 1958, p.192-210. 
Disponível em: http://www.tandfonline.com/doi/abs/10.1080/00393385808599792. Acesso em 04 jan 2017.

WISEMAN, D. J. The Vassal-Treaties of Esarhaddon. London: British School of Archaeology, 1958.

WOLFF, Hans Walter. Antropologia do Antigo Testamento. São Paulo: Hagnos, 2007. . The Hermeneutics of the Old Testament: Essays on Old Testament Hermeneutics. Claus Westermann (Ed.). Richmond: John Knox Press, 1963.

Fortress, 1973. . The Old Testament: A Guide to Its Writings. Philadelphia:

YERUSHALMI, Yosef H. Zakhor: Jewish History and Jewish Memory. Seattle: University of Washington Press, 1996. 